\title{
The Controversy Surrounding The Man Who Would Be Queen: A Case History of the Politics of Science, Identity, and Sex in the Internet Age
}

\author{
Alice D. Dreger
}

Published online: 23 April 2008

(c) Springer Science+Business Media, LLC 2008

\begin{abstract}
In 2003, psychology professor and sex researcher J. Michael Bailey published a book entitled The Man Who Would Be Queen: The Science of Gender-Bending and Transsexualism. The book's portrayal of male-to-female (MTF) transsexualism, based on a theory developed by sexologist Ray Blanchard, outraged some transgender activists. They believed the book to be typical of much of the biomedical literature on transsexuality—oppressive in both tone and claims, insulting to their senses of self, and damaging to their public identities. Some saw the book as especially dangerous because it claimed to be based on rigorous science, was published by an imprint of the National Academy of Sciences, and argued that MTF sex changes are motivated primarily by erotic interests and not by the problem of having the gender identity common to one sex in the body of the other. Dissatisfied with the option of merely criticizing the book, a small number of transwomen (particularly Lynn Conway, Andrea James, and Deirdre McCloskey) worked to try to ruin Bailey. Using published and unpublished sources as well as original interviews, this essay traces the history of the backlash against Bailey and his book. It also provides a thorough exegesis of the book's treatment of transsexuality and includes a comprehensive investigation of the merit of the charges made against Bailey that he had behaved unethically, immorally, and illegally in the production of his book. The essay closes with an epilogue that explores what has happened since 2003 to the central ideas and major players in the controversy.
\end{abstract}

A. D. Dreger $(\bowtie)$

Medical Humanities and Bioethics Program, Feinberg School of Medicine, Northwestern University, 750 N. Lake Shore Drive,

Suite 625, Chicago, IL 60611, USA

e-mail: a-dreger@northwestern.edu
Keywords Transsexualism $\cdot$ Transgenderism $\cdot$ Gender identity disorder - Autogynephilia - Identity politics . Institutional review board · Human subjects research

\section{Introduction}

This is not a simple story. If it were, it would be considerably shorter. The basic outline goes like this:

In the spring of 2003, J. Michael Bailey, a psychology professor and sex researcher at Northwestern University, published a book called The Man Who Would Be Queen: The Science of Gender-Bending and Transsexualism with Joseph Henry Press, a National Academy of Sciences imprint (Bailey, 2003). A popularization of certain areas of sexology research, the book was quickly praised by some reviewers (e.g., Cantor, 2003; Kirkus Reviews, 2003; Osborne, 2003) and denounced by others (e.g., Beatty, 2003; McCloskey, 2003a; Mundy, 2003). Although the book discussed a wide range of topics, including male homosexuality and gender identity development in intersex children, it was Bailey's portrayal of maleto-female (MTF) transsexuals that caused a firestorm. That portrayal, based on Ray Blanchard's taxonomy of MTF transsexualism (elaborated below), drew ire from a number of prominent transgender activists who found it profoundly insulting to their senses of self and damaging to their public identities. They argued that the book was obnoxious, wrong and, most importantly, that it would seriously hurt transwomen and their loved ones in its misrepresentation of their experiences and identities (see Conway, 2003a).

As documented below, dissatisfied with the option of merely criticizing the book, a small number of transgender activists worked to try to ruin Bailey professionally and personally. Largely under the leadership of three prominent transwomen-Lynn Conway (a world-renowned computer 
scientist at the University of Michigan), Andrea James (a Hollywood-based trans-consumer advocate and an entrepreneurial consultant on trans issues), and Deirdre McCloskey (a Distinguished Professor of Economics, History, English, and Communication at the University of Illinois at Chicago)_-they organized charges of scientific misconduct against Bailey, including charges that he lacked informed consent from research subjects, that he failed to obtain Institutional Review Board (IRB) permission for human subjects research, and that he had sexual relations with a transsexual research subject. They successfully pushed for a top-level investigation of these charges at Northwestern University and for numerous press reports about Bailey's alleged misdeeds. They successfully arranged a protest against the book's nomination for a Lambda Literary Foundation (LLF) award and tried to get Bailey's colleagues (including his closest departmental colleagues) to turn against him or at least distance themselves from him. They devoted elaborate Websites to criticizing and mocking him and his book and anyone with any positive relationship with him. One activist in particular, namely Andrea James, also used the Web to publicly harass Bailey's children, his ex-wife, his girlfriend, and his friends.

In short, the controversy over Bailey's book got about as ugly as it could. So very intense have been feelings around the Bailey controversy that several people were frightened to speak to me when I sent them inquiries about it a good 3 years after the book's publication. A few people who heard I was interested in writing a history of the controversy even tried to talk me out of it. Most were concerned that I would suffer personal harassment for researching and publicizing this history, and a few worried that no good would come of it because it would only inflame tensions and further entrench the players. Although I expect that the first concern is legitimate given what I've learned, I believe that this history has the potential to calm and even quell some of the tensions that persist. This history is worth tracking, too, in order for scholars, journalists, politicians, funding agencies, university administrators, publishers, and others to appreciate what can happen in an Internet-rich age of identity politics when a university-based researcher takes a controversial public stand, especially if that stand relates to sex, gender, or sexuality.

I also believe that a scholarly history of this controversy is critically necessary to advancing both transgender rights and sexology, two things about which I care deeply. As I have researched the following history, I have run across many people who labor under erroneous beliefs about what happened, and those misunderstandings need to be corrected because they are adversely affecting many people's lives and actions. Perhaps most importantly, in this work I have encountered a substantial number of transgendered persons and scholars of sex (and some people who are both) who are not entrenched in an "us versus them" mentality, but who nonetheless have been repeatedly silenced, misrepresented, or misheard by those who assume one must side with an "us" or a "them" since the backlash against The Man Who Would Be Queen. That continued, vigorously policed, "us versus them" partisan behavior is hurting science as well as individual trans people and it is time for it to stop. As I show here, the story of the controversy over The Man Who Would Be Queen is significantly more complicated than the on-the-street, "good versus evil" cartoon versions of it, and that matters for many people, individually and collectively.

This essay is divided into six sections: Part 1 explains my background and methodology; Part 2 provides a history of what went into the book ultimately entitled The Man Who Would Be Queen; Part 3 puts forth what I believe to be the only careful exegesis of the treatment of transsexualism in Bailey's book; Part 4 traces the backlash against the book and the book's author, including how the backlash began, who led it, how it morphed, and the form it ultimately took; Part 5 examines the merit of the charges made against Bailey that he had behaved unethically, immorally, and illegally in the production of his book; Part 6 constitutes an epilogue that sketches out what has happened since the backlash to the key players and ideas in the controversy.

\section{Part 1: My Background and Methodology}

By way of background, since it matters to the story I am about to tell, let me explain that when Bailey's book came out in 2003, I had not heard of him except to know vaguely of the twin studies he had coauthored (Bailey \& Pillard, 1991; Bailey, Pillard, Neale, \& Agyei, 1993), and I knew relatively little about transsexuality. My work as an historian and patient advocate focused on intersex (i.e., congenital anomalies of sex chromosomes, gonads, and/or anatomic sex), particularly on the clinical treatment of intersex in childhood. In addition to being an Associate Professor of Science and Technology Studies at Michigan State University, I was an intersex activist. I became intimately involved in the intersex rights movement starting in 1996 when Cheryl Chase, the founder of the Intersex Society of North America (ISNA), read my first publication on the history of intersex and asked me to help change the then contemporary medical treatment system for intersex children (Dreger, 2004). By 2003, when Bailey's book hit the Web and the stores, I had served as the Chair and President of the Board of Directors of ISNA for 5 years. From then until I retired from ISNA in late 2005, I served alternately as Chair of the Fundraising Committee, Chair and President of the Board of Directors, and Director of Medical Education. I think it is fair to say I am generally considered one of the chief architects of the intersex patients' rights movement. My two books and numerous articles on the subject have consistently argued that the standard of care needs to be changed because-among other problems, such 
as its lack of evidence-base and violation of generally accepted ethical principles-it is motivated by homophobia, sexism, heterosexism, and, more generally, fear of genderblurring (see, e.g., Dreger, 1998; Dreger \& Herndon, in press). Thus, although I am heterosexual and not intersex, I've often been considered (and consider myself) a queer rights activist as well as an historian of sex and gender.

As best I can recall, the first I heard of Bailey's book was via a phone call in 2003 from Lynn Conway, the person whoexcept for Bailey himself - turns out to have played the most important role in this story. I knew Conway because she was a generous donor to ISNA and because she had been personally supportive of Cheryl Chase, who had become my close friend as well as my collaborator. In my capacity as a leader of ISNA, I occasionally solicited donations from Conway and thanked her for her donations. Shortly after the publication of The Man Who Would Be Queen (hereafter TMWWBQ), Conway called to tell me it was a terrible and dangerous book, a book that called transwomen like her "perverts." My recollection is that I gave her this advice: "All publicity is good publicity. Ignore Bailey and he'll go away. Don't feed his publicity machine."

I believe it was a few months later that my friend and colleague Paul Vasey also called to talk to me about the book. I had met Vasey (a sex researcher at the University of Lethbridge) in February 2002 through a conference on sex and gender co-organized by Joan Roughgarden at Stanford University. Vasey was calling to ask me whether I knew I was listed as a supporter of Conway's anti-Bailey campaign on her University of Michigan Website (http://www.ai.eecs.umich. edu/people/conway), and whether I knew what was happening to Bailey and his family. I told him honestly this was all news to me, and while I was disappointed that someone was attacking Bailey's children online, it seemed to me that Bailey had stuck his hand into a buzzing hornet's nest and he should have expected to be stung. I then emailed Conway (p.e.c. ${ }^{1}$, August 12, 2003) to tell her she should not list me as a supporter of her campaign as I had not read the book and it was embarrassing to have my colleagues think I had formed an opinion about a book without reading it. She removed my name and sent me a reply encouraging me to support her campaign against the book (p.e.c., August 14, 2003). But by that point the whole thing seemed ugly enough that I had no interest in getting involved and being distracted from my work on intersex rights. I did read the book sometime around late 2003 or early 2004, and — judging by my marginalia - I found it generally lively and well written, unnecessarily snide or even contemptuous in places, lacking in evidentiary support (the book has "further reading" suggestions but no citations), and full of claims and ideas that I knew very little about. I marked it up copiously and put it down.

1 “p.e.c." stands for "personal email communication."
In November 2004, four years into trying to balance motherhood with full-time university work and near-full-time volunteer intersex activism, I gave up my tenured position at Michigan State University so that I could devote more time to my activism, writing, and speaking, and to my family's domestic life. In 2005, I accepted a part-time faculty appointment in Medical Humanities and Bioethics at the Feinberg School of Medicine of Northwestern University in Chicago, and in February 2006, as Vasey was coming to Chicago to work with me on a project proposal about sexual diversity, he insisted it was time I meet Bailey. Bailey works on the Evanston campus of Northwestern, and I work on the Chicago campus, so we had no reason to meet through our ordinary work. Being good friends with both Bailey and me, Vasey was bothered that Bailey assumed me to be a senseless postmodernist beholden to political correctness and that I assumed him to be a homophobic, transphobic, sloppy scientist. What I knew about Bailey I knew partly from reading his book but mostly from hearing about him through the gender activist grapevine: he was supposed to have abandoned his wife and children, to have slept with a research subject, to have done human subjects research with no oversight, to be against sex reassignment surgery (SRS) for transgender people, and so on. It was only my enormous respect for Vasey, whom I knew as an openly gay man and a very good scientist, that made me agree to meet the infamous Bailey.

Upon our meeting over dinner with Vasey in Chicago's Boys' Town (the gay neighborhood near where Bailey lived) in February 2006, I was surprised to find Bailey to be apparently intelligent, open-minded, scientifically careful, and nonhomophobic. As I recall, about an hour into our conversation I asked him point-blank whether it was true he had slept with a research subject, and he answered in a legalistic and exasperated fashion, saying that, even if he had, that would not have been a violation of IRB rules. Intrigued, in the next few days, I looked up Bailey's journal articles and his Website and discovered, besides an impressive peer-reviewed publication record, that Bailey appeared to have quite good relations with the children and ex-wife he supposedly had abandoned. What was the truth, I wondered?

In May 2006, knowing of my increasing curiosity in the matter, Bailey emailed me to let me know that Andrea James had been invited by Northwestern University's Rainbow Alliance to speak at the Evanston campus of our university (p.e.c., May 9, 2006). At that point, I had not done any serious investigation into the history of the controversy, so I asked Bailey to tell me who James was exactly. He explained that she was the person who was so angry about what he said in his book that she had put up on her Website (http://www.tsroad map.com) pictures of his children with their eyes blacked out, asking whether his young daughter was "a cock-starved exhibitionist, or a paraphiliac who just gets off on the idea of it?" and saying that "there are two types of children in the 
Bailey household," namely those "who have been sodomized by their father [and those] who have not" (James, 2003a). I understood this was meant by James to be a parody of Bailey's alleged treatment of transsexuals in his book (James, 2003a), but I was disgusted by this intimidation tactic, having myself been subject to intimidation by right-wing activists who didn't like my pointing out how intersex challenges the assumptions inherent in anti-"same-sex" marriage legislation. I wrote to Northwestern's Rainbow Alliance to express my dismay that someone of this sort would be invited to our university (p.e.c., May 11, 2006). I told them that, given her unethical tactics, I thought James was not the sort of person who was good for a scholarly institution nor the sort who was good for transgender rights. They did not respond. So, on May 13, 2006, I blogged about my dismay on my personal Website (Dreger, 2006).

This blog led to a torrent of email from every camp imaginable - indeed, many camps I had not imagined existed. Many sex researchers and Bailey's daughter wrote to thank me for speaking out against James. Some transgender women wrote to tell me that, no matter what James had done, Bailey's actions had been reprehensible and those were the actions to which I should direct my criticisms. Most interestingly to me, a surprisingly large number of transgender women wrote to tell me that they had been harassed and threatened by James for daring to speak anything other than the standard "I'm a woman trapped in a man's body" story. Many (though by no means all) of those women found Bailey's version of their identities inaccurate, oversimplified, and/or just plain obnoxious (and, from my rather vague memory of the book, I was inclined to agree), but they wanted me to know that they, too, thought James was harmful. Almost universally those who wrote to me - including sex researchers-asked that I not ever quote them or mention them by name. They feared being attacked by James, as Bailey and others had been.

When I posted my blog, I made a point of emailing James to tell her about it and to ask her to stop undermining progress in transgender rights with her incontinent attacks (p.e.c., May 16, 2006). She was none too pleased and sent me back a series of hostile emails, including one referring to my 5-year-old son as my "precious womb turd" (p.e.c., June 1, 2006). She also came to my departmental office (I was not there) and then emailed me, subject line "Mommy Knows Best," saying, "Sorry I missed you the other day. Your colleagues seem quite affable, and not as fearful as you. [...] Bad move, Mommy. [...] We'll chat in person soon" (p.e.c., May 27, 2006). At that point, concerned for my son and office colleagues, I forwarded the whole of the communications to my Dean, who put me in touch with university counsel, who-given James's threatening tone and her history-recommended I alert campus police. I told the police I was not aware of James ever having been physically violent; she seems simply to harass and intimidate.
Since then, James has been trying to undermine my reputation as an intersex activist and scholar, which she explicitly warned me by email she would try her best to do ( "I'll do what I can to assist [...] in discrediting you"; Andrea James, p.e.c, May 27, 2006). By early October 2006, I found myself featured on the very first page of James' massive attack and advice site (http://www.tsroadmap.com). There my name was linked to an erroneous account of my intersex activist history (Hinkle, 2006). As bizarre as this sounds, in trying to intimidate or exact revenge on me for blogging about her tactics, James has chosen specifically to focus her energies on undermining the emerging medical terminology of "disorders of sex development" as a replacement for the umbrella term "intersex" and all terms based on the root "hermaphroditism." ("I am [...] going to do what I can to discredit your lame-ass DSD model"; James to Dreger, p.e.c., June 1, 2006.) Apparently, James hopes she can get my fellow intersex activists angry at me for helping to introduce the new terminology, a terminology some find pathologizing and regressive (Dreger \& Herndon, in press). Intersex friends and allies tell me that, out of anger at me personally, James does now seem to be effectively sowing anger and dissention in the intersex world as she has done in the transgender world. I consider this development sad, but inadequate cause to be silenced.

I mention my own experience with James to help explain why I decided to devote as much time and energy to this scholarly history as I have. James's expansive attempt to intimidate (and presumably silence) me simply for questioning her once-along with the unsettling experience of hearing bits of alternative histories from and so much fear among sexologists and transgender women-left me with a strong desire to know the truth about Bailey's work and the controversy surrounding it. It reminded me too much of the history of modern intersex treatment - where claims about truth differed so radically among activists and sexologists - to leave the historical record unclear. So, early in the summer of 2006, I decided to undertake this scholarly history and began collecting available sources. I also began contacting people who I thought could give me useful unpublished sources, oral histories, and general advice about the project.

This article therefore draws on all of that material. Before I interviewed sources orally, I let them know I would take notes while we talked and that they could correct the notes however they wished before I would use them. They were invited to add, delete, or otherwise change whatever they wished in the notes, regardless of what they had actually said; this ensured they were represented accurately. (Oral-interview citations in the reference list thus include both the date of the interview as well as the date the corrected notes were returned.) If I interviewed them by email, I let them know I would feel free to quote from their responses unless they specifically indicated otherwise. (In-text citations referring to emails are marked "p.e.c." and provide the date the email was sent.) 
As is the case for all histories, this is a partial history based on available sources and including what this historian judges relevant and important. Unlike some histories, it has the added advantage of being extensively reviewed prior to publication. Before this article was even submitted for peer review, I solicited responses to drafts from 12 transgender activists and sex researchers in disparate disciplines. (Several of the presubmission readers are both trans activists and sex researchers.) To the extent possible, I have sought input from all of the major players in this story, although I confess that I did not contact James for this project because, given our history, I did not feel safe doing so nor did I think productive dialogue with her was possible.

I did try contacting Lynn Conway through numerous emails to let her know that I was working on this project and to give her a chance to give me any input she wished. I also told her in my emails that I hoped that the Editor of the journal that eventually published my paper would give her and Baileywhom I believe to be the two most important characters in this story - the opportunity to formally respond to my paper in the same issue. When I decided to undertake this work, I felt sure Conway would talk to me because she had spent so much energy on Bailey and his book and because we had had a cordial history. In addition to our positive fundraiser-donor relationship through ISNA, we had over the years also touched base about parallel efforts at our universities (Michigan State University and the University of Michigan) to ensure that our institutions' anti-discrimination policies adequately protected transgender people. Several years ago, Conway also very kindly at my request came to my home to provide one-on-one peer support for a colleague of mine who was considering sex reassignment. (I made them lunch and then left them alone at my house to talk.) When she did not answer my numerous emails about this project, I sent letters to her office and home. Still I heard nothing, although I knew from new posts at her Website that she was still interested in Bailey's doings. So I tried calling her at work, but her department told me she is now a professor emerita and no longer maintains a phone there. Consequently on August 16, 2006, I called her at home, because I wanted to be sure she had a chance to represent herself beyond the published record.

I finally reached Conway that way and we had a phone call that lasted about a minute. She surprised me by being extremely hostile at the outset. She also would not answer my simple question about whether she was willing to speak to me on the record. This confused me-why would she not just tell me whether or not she wanted to speak on the record? - and I said as much. She responded that it was very strange that I would call her at home. I told her how many other ways I had tried to reach her with no response before finally calling her home. She then said that I was stalking her and added that she would circulate this fact widely. Since it was at that point clear she didn't want to speak to me, and since I was afraid of being accused of stalking, I said goodbye and gave up. (This account is based on notes I made immediately following the call.) I take this interaction to mean Conway does not wish to provide input on this work. Fortunately, Conway's extensive Website and the oral histories I have conducted with others provide substantial documentation about and insight into her role in this history.

I also invited Deirdre McCloskey to talk with me on the record about this history and told her I would be happy to consider any material she wished (p.e.c., December 30, 2006). McCloskey and I had met once, in 2001, when we both spoke on a panel with California State University, Northridge FTM philosopher Jacob Hale at the University of Illinois in Chicago. (I recall that, at the lunch we had together, she autographed my copy of her autobiography.) As part of this project, I sent her a list of specific questions regarding her role based on what I had learned from other sources, and she sent back very brief answers on which I draw here (p.e.c.'s, January 22, 2007). McCloskey refused to tell me anything more substantial unless I first proved to her, by showing her what I was writing, that I agreed with her positions (p.e.c.'s, December 31, 2006, and February 4, 2007). I explained that, as a scholar, I do not make that kind of deal with potential sources. As in my experience with Conway, I found myself confused as to why McCloskey would not want to clearly self-represent to me her critical role in what happened to Bailey following publication of his book. I can only guess they want attention paid only to Bailey and his actions, not to the history of the backlash against him and his book. In any case, as with Conway, for my account of McCloskey's role I draw on the available sources-many of which happen to be posted on Conway's site. To maximize fairness and accuracy, I gave McCloskey a list of the specific pages from Conway's site that I was using to write about her, and asked McCloskey to correct any misrepresentations of her actions contained therein; she corrected none.

As this history shows, James, Conway, and McCloskey played pivotal roles in the controversy surrounding $T M W$ $W B Q$, although their personal stories do not appear in the book, except insofar as Bailey briefly discusses McCloskey's memoir in the "further reading" section (Bailey, 2003, p. 215). But two other women whose stories did appear in the book also came to play important roles in the controversy. These are Charlotte Anjelica Kieltyka (known in the book as "Cher Mondavi") and the woman called "Juanita." Before I ever had a chance to contact her, Kieltyka called me at my office in June 2006; she had read my blog about James as well as some of my writing on bioethics, and she was calling in the hopes I might help her continue her ongoing campaign against Bailey. I listened to her extensive concerns and then, on a later date, told her I had decided to work on this history and offered her the opportunity to go on the record with her memories and opinions. She chose to do so through a series of lengthy telephone interviews (totaling about 11 hours) and numerous 
emails. As with all subjects, I let Kieltyka change and approve the written versions of our verbal interchanges so that they contained exactly what she was willing to have on the record. I reminded her frequently that all emails were on the record.

I have not spoken to the woman who is called "Juanita" in this history as she was called in Bailey's book. As we shall see, "Juanita" is the woman who accused Bailey of, among other things, having had sexual relations with her when she was his research subject (Bailey, 2005). Even though she has gone by at least two pseudonyms ("Juanita" and "Maria") in her many public dealings with Bailey, in my research I quickly figured out her real identity. Indeed, it was impossible not to figure out who she is, because Juanita has chosen before and since $T M W W B Q$ to be so very public with her autobiography and her physical image. She even let Kieltyka take a semi-nude, erotic photograph of her, with her face veiled (Kieltyka, 2003a), a photograph Conway herself then reproduced and specifically identified as being of the "Juanita" of $T M W W B Q$ (Conway, 2003b). (Conway says on her site she reproduced this photo of Juanita to counter what she sees as Bailey's negative representations, by "show[ing] the inner grace and beauty of a young transsexual woman" [Conway, 2003b]. I'm not sure how it represents the subject's inner qualities, but it certainly doesn't leave much about her outer qualities to the imagination.)

Conway's “Transsexual Women's Successes" site provides five photographs of Juanita (this time with her face showing in plain view and her clothes on) along with a detailed autobiography of Juanita, including an oblique reference to her encounters with Bailey (Maria, 2004). Although the photographs and autobiography are reproduced under the name "Maria" on Conway's "Successes" page, "Maria's" autobiography obviously matches the already-published biography of Juanita in Bailey's book. "Maria's" face as shown in plain view on Conway's site also obviously matches the face found in a feature story on Kieltyka and Juanita that was published with their consent in 1999 in the Daily Northwestern, the student newspaper of Northwestern University, an article to which no fewer than four sources (including Kieltyka) referred me. For that feature story, Kieltyka and Juanita gave the student reporter permission to use their photos as well as their real first and last names-pre-gender-transition as well as post (Gibson, 1999). The match between the representations in the Daily Northwestern article (February 1999), in Bailey's book (April 2003), and on Conway's page (April 2004) is the reason it became obvious to me who Juanita really is, although below I also document additional public real-name presentations by Juanita.

I also document that Juanita consented to all of those public representations. If Juanita has wanted to hide her real identity, she hasn't tried very hard. Nevertheless, I've decided here not to give Juanita's real name because she hasn't chosen to publicly connect the dots as I have easily done (and as anyone else researching this history would quickly do). For this history, I did try to contact Juanita through the email address provided in her autobiography on Conway's site (I received no response to my email [p.e.c., December 16, 2006], not even an "undeliverable" postmaster response), and through Kieltyka (who told me she checked with Juanita and that Juanita didn't want to talk to me [Kieltyka to Dreger, p.e.c., September 20, 2006]). I also tried to find her through public address lists, but her real name turns out to be common in the Chicago area, where I assume she still lives, and it seemed inappropriate to write to all women with her name seeking the one person for whom I was looking, particularly given that Juanita did not write back to the email and apparently told Kieltyka she didn't want to talk with me.

In terms of other important sources, as I elaborate below, one journalist repeatedly refused to explain to me her odd part in this history. No sexologist refused my requests for interviews. I am grateful to the more than 100 people who answered my requests for information and help, particularly Charlotte Anjelica Kieltyka and J. Michael Bailey who each provided me enormous amounts of information and documentation, and tolerated impressively my sometimes uncomfortable questions.

\section{Part 2: The History of the Book that Became TMWWBQ}

Chicago-based therapist Randi Ettner might be surprised to learn that she was the impetus for the book that became $T M W W B Q$. After Michael Bailey attended a reading by Ettner of her book Confessions of a Gender Defender (Ettner, 1996) at a local Barnes \& Noble bookstore in June 1997, he was so frustrated by what he saw as gross inaccuracies in Ettner's account of transsexualism that he decided he would write a book of his own (Bailey, 2006b; Bailey to Dreger, p.e.c., August 22, 2006). By October 1997, he had begun writing notes for that book under the working title Sexual Difference. The draft dedication turned out to be, in retrospect, as ironic as they come: "For my children. May they learn life's hardest lessons from books" (Bailey's personal files; Bailey to Dreger, p.e.c., August 22, 2006).

From the start, Bailey intended this book to be very different from anything he had published before. Whereas most of his previous work consisted of peer-reviewed articles for scientific journals, this book would be a popularizationbased on certain sexological findings of his lab and others, but replete with vivid stories of people the author had met, stories provided to put a human face on those findings. Along with accessible, abbreviated accounts of key scientific studies, the book would also feature the author's hunches, speculations, and personal opinions. It would include suggestions for further reading, but no other documentation (Bailey, 2006b). Thus, $T M W W B Q$ was never envisioned as a work of science in any 
traditional sense; instead, Bailey viewed the book as his chance to expose to the masses what he saw as the often politically incorrect truth about "feminine males": boys diagnosable with "gender identity disorder" (GID); surgically feminized, genetic male children; male homosexuals; drag queens; heterosexual male crossdressers; and MTF transsexuals. Bailey also saw the book as an opportunity to make some money; when he was ready to sell the book, he engaged an agent, Skip Barker, who negotiated in November 2000 a contract and an advance from Joseph Henry Press (p.e.c., Bailey to Dreger, October 2, 2006). Joseph Henry Press is "an imprint of the National Academies Press [...] created with the goal of making books on science, technology, and health more widely available to professionals and the public" (Bailey, 2003, copyright page).

Bailey had originally considered also writing about "masculine females" (e.g., tomboys) in his book, but soon decided that that would have to wait for a second volume (Bailey, 2003, p. xii). But it was his long-term interest in masculine females that had led Bailey to meet one of the transwomen who would become a major character in $T M W W B Q$ and in the controversy that followed: Charlotte Anjelica Kieltyka. Kieltyka, who lived in the Chicago area, called Bailey after seeing him in a 1993 Dateline NBC television segment on tomboys (Copaken, 1993). Kieltyka sought out Bailey to suggest that he might be interested in "the other kind of 'tomboy'-those transsexual women named 'Tom' that were born a 'boy'.... 'Tomboys' like me" (Kieltyka, 2006a). She explained to Bailey that, unlike the media stereotype of transsexual women, she was attracted to women, and that women like her "were NOT inconsistent with masculine lesbianism" (Kieltyka, 2006a). In their subsequent conversations, she also explained she had been a rather boyish boy and had worked as a car mechanic as well as being an artist.

Sometime in 1994, Bailey and Kieltyka met for the first time, at Bailey's office. At their very first meeting, Kieltyka brought along "show and tell" items (Kieltyka, 2006c). These included realistic prosthetic vulvas complete with pubic hair. Kieltyka explained to Bailey how, before she had SRS, she used to tuck and glue her penis into her body (made easier by having been born with only one testicle) and glue on one of these vulvas to achieve the appearance of female genitalia. Kieltyka also explained how she had constructed realisticlooking prosthetic breasts and how, before her sex change, she wore these with female masks and wigs to achieve a feminine appearance she had found both erotic and transformative. Kieltyka told me that she saw "the cross-dressing with the mask [as] a kind of transitional thing - the fetish objects- the breasts and the plastic vagina - an important part of a 'dress rehearsal' [....] WITHOUT IT-without this fetish transformative phase-I would never have seen myself as a womannever realize[d] that I was a transsexual woman." She went on: "I needed to see myself, like an artist following a creative path, realizing only after you created it; the realization [of being a transsexual] came after the creation" (Kieltyka, 2006b).

According to Bailey, Kieltyka came across as an intelligent, warm, creative, outgoing woman with a good sense of humor and a strong interest in telling people about herself. (This is all consistent with my experience in my extensive interviews with Kieltyka.) Kieltyka immediately and repeatedly told Bailey vivid details about her life, and she encouraged Bailey to accompany her to the local bars frequented by pre- and post-op transsexual women and drag queens where Kieltyka was familiar with many of the regulars (Bailey to Dreger, p.e.c., October 2, 2006). In his book, Bailey thanks Anjelica Kieltyka for "introduc[ing] me to the Chicago transsexual community and [teaching] me a great deal by being honest and open" (Bailey, 2003, p. xii).

Not long after their meeting, Kieltyka saw in Bailey a possible aide to the advocacy work she was doing with pre- and post-op transsexuals in the Chicago area. Kieltyka had been working with sympathetic clinicians at Cook County Hospital and elsewhere to get local transsexual women prescription feminizing hormones (as an alternative to black-market hormones) and to try to convince the hospital to restart its SRS program. She had also been referring and accompanying transsexual women to a support group at Good Samaritan Hospital run by Wanda Sadoughi, a psychologist who also sometimes provided letters to pre-op women in support of their requests for SRS (Kieltyka, 2006a). Why did these women need letters from people such as Sadoughi? Surgeons who followed the fourth version of the Standards of Care as laid out in 1990 by the Harry Benjamin International Gender Dysphoria Association (HBIGDA) required two "favorable recommendation[s] for surgical (genital and breast) sex reassignment," including at least one from a "doctoral level clinical behavioral scientist" (Walker et al., 1990, Sect. 4.7.5). Version Five of the Standards of Care, adopted in 1998, called for "a comprehensive evaluation by [two] qualified mental health professional[s]" (Levine et al., 1998, p. 28). Thus, during the time in question here, respected surgeons performing SRS typically required patients to produce evidence from two qualified psychological professionals that the applicant fit HBIGDA's eligibility and readiness criteria for SRS.

Sometime around 1996, Kieltyka asked Bailey whether he would help out some of her friends and protégés by providing them with letters in support of their requests for SRS. Bailey was amenable to Kieltyka's request. His understanding was that, so long as he made clear in his letters what his professional status was, there would be no problem reporting simply what he observed in terms of a pre-op transsexual woman's gender identity presentation, her apparent understanding of the surgery, and her likelihood of adjusting well after SRS. Nowhere in his letters did Bailey say that he was these women's therapist or that he counted under the HBIGDA 
Standards of Care as a "qualified mental health professional"; in each, he simply stated his university position, said how many times he had talked with the subject, and included his c.v. (Bailey, 2006b; for examples, see Conway, 2004d). Whether or not a surgeon accepted his letter as an adequate recommendation would be up to the surgeon, just as it was up to the surgeon more generally which parts of the HBIGDA Standards of Care he or she would follow.

Bailey's letters were typically less than one page long and were based on a small number of interviews (usually two or three) conducted over a span of 6 months or more (Bailey, p.e.c.'s, October 2 and 3, 2006). Kieltyka often attended these interviews because she saw herself as an advocate for the transsexual women seeking letters (Kieltyka, 2006a). Bailey provided somewhere between five and ten of these letters, including one for Juanita (Bailey, p.e.c., October 3, 2006), and he neither sought nor received remuneration for these letters (Bailey, 2006b); like Kieltyka, he saw the work as a sort of voluntary public service to local transsexuals who were already living as women and who could generally not easily afford months or years of the psychological therapy that typically preceded the production of a psychologist's letter regarding SRS. Bailey recalls, "I was definitely sympathetic" to the transwomen who asked him for letters of recommendation: "I had little doubt that they would be happy after SRS, and I sympathized with all they'd been through. I wrote the letters as a favor to them, the transsexual community, and to Anjelica [Kieltyka]" (Bailey, 2006b).

Kieltyka also arranged with Bailey opportunities to present to students in his Human Sexuality class herself, her history, and her understanding of transsexuality. She says her "lectures were an opportunity to do 'outreach'; to educate AND entertain" (Kieltyka, 2006a). As in the case of other guest speakers, these presentations took place after the regular class session and were optional but heavily attended; between 1994 and 2003, a total of several thousand Northwestern University students saw Kieltyka's annual appearances (Bailey, 2006b; Kieltyka, 2006b). In these presentations, held in a large auditorium to accommodate the class size, Kieltyka showed and explained a series of still images using overhead projection. She began with two pictures, first one "of an 'erratic' rock formation-sticking out in the middle of an incongruent landscape/environment," and then one of herself as "a beautiful, attractive woman in the middle of an all guy and Catholic high school 30th reunion." She saw herself in the second picture as being very much like the erratic boulder of the first, and she posed the question, "How did she get there?... How did I get here?" (Kieltyka, 2006a).

To Bailey's students, Kieltyka also presented a short video compilation she had made. The compilation included "before and after" shots of herself-for example, clips of her former self (Chuck) playing the hammered dulcimer with a local Irish folk group, and of her post-SRS self (Charlotte Anjelica) sitting in a recording studio. In the recording studio segments, Kieltyka is seen surrounded by television monitors and recording equipment. She is wearing a white bikini, drinking a cocktail, and explaining her history (Kieltyka, 1999).

No doubt to the surprise of Bailey's students that video compilation actually begins with a pornographic segment Kieltyka had made for herself pre-SRS. In it, as Donna Summer sings "Love to Love You Baby" in the background, Chuck appears as a nude woman through use of prosthetics, including false breasts, a glued-on vulva (with his penis glued up inside his body), a female mask, and a platinum blonde wig. The woman whom Chuck appears as masturbates through simulated finger-clitoral stimulation and through the use of a dildo attached to the floor; she straddles the dildo and thrusts up and down so that it looks as if the dildo is going in and out of her vagina. (It was actually going in and out of Chuck's anus.) Kieltyka overlaid an audio clip from a porn video in this segment to provide the sound of a woman reaching orgasm. Immediately after this segment, the compilation cuts to a postop scene of Anjelica standing topless in a bikini bottom and moccasins, looking radiant and being dramatically bathed in a rushing waterfall. She brushes back her long dark hair with her hand and motions to two nearby women unknown to her to also take off their tops. They decline (Kieltyka, 1999, 2006e).

Kieltyka explained to me that she used this video in Bailey's class to show an important part of her profound transformation from man to woman. In producing the video,

I was freeing that woman that was trapped inside my body. Just as Michelangelo would free the image from the block of marble, or Pygmalia, the carving became the woman that he desired. I became the woman I desired, but it wasn't a sexual desire, because when I knew and stepped out of the trans state, the ritual state, I knew that was me behind the mask. I could not use that video to masturbate to, because I knew it was me. I could not become aroused if I wasn't wearing a mask. I had to become the other. (Kieltyka, 2006c).

She also said about the video:

It was a kind of a simulation, almost like a pilot learning to fly a commercial airline[r] first goes through a simulator until it becomes almost second[-]nature or instinctive-a simulator that was also a "stimulator" ....and the higher the stimulation[,] the greater the positive feedback[....] it was all religious; technical; psychological; artistic; sexual....even pornographic. (Kieltyka, 2006b; ellipses in original unless in brackets)

In other words, Kieltyka believes that the stimulation she felt in producing the video-simulation allowed her to understand she was a woman inside. To Kieltyka's mind, the video also demonstrates that the prosthetics and women's lingerie 
she used to crossdress prior to her SRS are very much like fetishes in Native American cultures; she specifically likens them to the eagle feathers and animal furs used in certain Native American ceremonies. She is thinking of those Native Americans who "had animal fetishes that the individual[,] in their trans state or their ritual state, would don [...] and they would become those animals that had special powers within them. The person was transformed into or transubstantiation took place, using the fetish elements, they became those entities" (Kieltyka, 2006c). She explains that this is why, in the post-op waterfall scene that immediately follows the preop pornographic scene, she looked somewhat Native American, with long, dark hair and moccasins: "it was symbolic of a baptism, a kind of native American nature child, born again, emerging from the water like a Venus" (Kieltyka, 2006b; see also Kieltyka, 2006e).

Kieltyka has also explained how women's “foundation garments" (bras, girdles, etc.) were truly foundational to her self, because they helped her understand who she truly is:

I saw [the foundation garments] as the foundation to a woman's sexuality, and that was where I ultimately saw the vagina and breasts as powerful fetish elements[....] If I could create or recreate those powerful fetish objects for myself-within myself[-]I would become the woman in appearance, most certainly, but also to correlate with my own identity that was buried and repressed for so many years-inside. It was substantive[.] (Kieltyka, 2006c).

Thus, as she explained to Bailey and his students, Kieltyka saw herself as undergoing not just a sex change, but a profound transformation which achieved an integration of material, emotional, and spiritual realities.

For his part, Bailey saw Kieltyka's story as constituting an open-and-shut case of autogynephilia. "Autogynephilia," a term coined by sex researcher Ray Blanchard in 1989, refers to the phenomenon of a person (in Blanchard's formulation, a natal male) being sexually aroused by the thought of himself as a woman (Blanchard, 1989; see also Blanchard, 2005). Now Head of Clinical Sexology Services at the Centre for Addiction and Mental Health in Toronto (formerly known as the Clarke Institute of Psychiatry) and Professor of Psychiatry at the University of Toronto, Blanchard has posited that autogynephilia constitutes an "erotic target location error" in which a male winds up with himself as the object of his heterosexual desire (Freund \& Blanchard, 1993). Though she has often talked about her lesbianism, i.e., sexual attraction to women, Kieltyka also sometimes had sexual relations with men, and has described herself as being bisexual (Bailey, 2003, p. 159; Gibson, 1999). This in itself did not make her story inconsistent with Blanchard's theory of autogynephilia; Blanchard (2005) noted that autogynephiles might present with a sexual history of heterosexuality (attraction to women), bisexuality, or even asexuality. And with her elaborate and highly creative history of erotic crossdressing, Bailey saw Kieltyka as a perfect example of autogynephilia. Indeed, the more he learned of Kieltyka and of autogynephilia, the more it made perfect sense to Bailey that many of Kieltyka's earliest sexual arousal experiences occurred when crossdressing and/ or imagining herself as a woman (Allyn \& Bacon, 2004; Bailey, 2003, p. 152; Kieltyka, 2006c).

In his work on transsexualism, Blanchard argued that there are actually two types of MTF transsexuals, with autogynephiles being one type and "homosexual transsexuals" being the other. In contrast to those identified as autogynephiles, homosexual transsexuals are understood to typically appear very effeminate from early childhood on (Blanchard, 2005). In Bailey's words, "From soon after birth, the homosexual maleto-female transsexual behaves and feels like a girl" (Bailey, 2003, p. 146). People with this form of transsexualism are, by definition, sexually attracted to other males, though notably their attraction is generally to heterosexual men. Blanchard termed them "homosexual" in keeping with Magnus Hirschfeld's taxonomic approach (Blanchard, 2005, p. 443), and he argued that MTF homosexual transsexuals who opt to undergo sex reassignment do so, in part, because being a woman makes more sense than trying to live as a very effeminate man attracted to heterosexual men. Blanchard's theory is, therefore, one that sees erotic desire as a central component of MTF transsexualism and indeed an impetus to sex reassignment. In Bailey's take on Blanchard's theory, whether one is talking of "homosexual" or "non-homosexual" (i.e., "autogynephilic") transsexuals, MTF transsexualism is fundamentally about sexuality - or more specifically, eroticism. Kieltyka's class presentations, including her video compilation and pre-op crossdressing "props," did little to persuade Bailey otherwise. The fact that she used the term "fetish" to talk about her "props" would only have added to his sense that her behavior represented classic fetishistic crossdressing — autogynephilia.

When she presented to Bailey's Human Sexuality students, Kieltyka usually brought along friends who were also postoperative transwomen, some of whom had, through Kieltyka, sought out and obtained SRS-support letters from Bailey. According to Kieltyka, these women (including Juanita) joined her in part out of gratitude to Bailey for his earlier help. But Bailey did not seek a quid pro quo; that is, he never asked a woman who came to him seeking an SRS letter to present to his class or to do anything else in exchange (Bailey, 2006b; Kieltyka, 2006a). Indeed, all of the co-presenters were arranged by Kieltyka, and all presented to his students after their surgical transitions had been accomplished. Bailey paid them for their presentations the same way he compensated his other post-class speakers, out of designated university accounts. Although it makes sense that the transwomen who got SRS-support letters from Bailey might have been grateful to Bailey for his help, none of them was so grateful that she 
declined the money he would offer for presenting. And, as with all of his after-class speakers, he let them present whatever they wanted; he did not require them or any other after-class speaker to say anything in particular. Most of them simply spoke plainly about what they saw as the relevant facts of their experiences and their bodies, and then they answered students' questions (Bailey, 2006b). None of Kieltyka's co-presenters gave the sort of elaborate, multimedia presentation Kieltyka did, and none did what Kieltyka chose to do twice: strip down to complete nudity at the end of her presentation, as a sort of grand finale (Bailey, 2006b; Bailey to Dreger, p.e.c., October 3, 2006). According to Kieltyka, she stripped "to show that even $40[-]$ something-year[-]old transsexual women that were lesbian and 'butch' in the head but 'fem[me]' in the body could be 'show girls' - attractive and sexy" (Kieltyka, 2006a).

To Bailey's mind, the transsexual women Kieltyka brought for SRS-support letters and as co-presenters turned out to be perfect examples of Blanchard's "homosexual transsexuals" (Bailey, 2005). They passed easily as women, they were attracted to heterosexual men, and they had been identified by themselves and others as feminine since early childhood. They did not have the history of erotic crossdressing Bailey saw in Kieltyka, though they did report histories of numerous and often casual sexual relationships with heterosexual men. This again was in keeping with Blanchard's findings. Thus, the patterns Bailey saw in Kieltyka and her associates supported Blanchard's theory of the two types of MTF transsexuals and (importantly) flew in the face of the accounts of people such as Ettner who saw transsexualism as representing a single phenomenon, one that had nothing to do with eroticism and everything to do with gender identity (Bailey, 2006b; Bailey to Dreger, p.e.c., August 22, 2006).

According to Ettner and many other gender therapists and theorists, the central problem pretty much any trans person faces is having a gender identity that doesn't match body type (Ettner, 1996, 1999). The primary reason for seeking SRS is to correct a mismatch between the transsexual's body and her gender identity, not to achieve any erotic goal. Mildred L. Brown, a therapist popular with many trans activists (including Conway and James), sums it up this way: "Transsexualism is not about sex, sexual behavior, or sexual orientation-it's about gender or, more specifically, gender identity" (Brown \& Rounsley, 1996, p. 20). To this way of thinking, trans people suffer from a sort of trick of nature, whereby they have the brain of one gender in the body typical of the other. Thus, the trans person has a sort of neurological intersex condition, typically understood to be inborn. Blanchard and Bailey would likely agree that homosexual transsexuals appear to be somewhat neurologically intersex, given their male anatomies and their histories of effeminacy and attraction to heterosexual males (Bailey, 2003, p. 159), but both would reject such a claim from a person they view as autogynephilic (which in their view would be all non-homosexual MTF people). And more importantly, both see eroticism and not some innate gender identity as the salient point. Both believe that eroticism is important in the explanation of and motivation for MTF transsexualism.

Although Kieltyka never saw herself as an autogynephile, judging by actions as well as copies of emails provided to me, the fact that Bailey saw her that way did not interfere significantly with their friendly relationship. Kieltyka told me recently that she and her transsexual friends "took it for granted that Bailey saw us the way we saw ourselves" (Kieltyka, 2006a), i.e., not as "autogynephilic" and "homosexual" in Blanchard's sense. Yet Kieltyka also distinctly remembers that Bailey considered her an autogynephile virtually from Day One: "I was aware that Bailey saw me as an example of autogynephilia, he thought so the very first day we met in his office" (Kieltyka, 2006b) when she showed him her pre-op crossdressing props. Certainly by late 1998, Kieltyka knew for sure that Bailey subscribed to Blanchard's theory and saw her as an autogynephile, because by that time she knew he was writing about her in a forthcoming book. After doublechecking the facts of her story with her by phone, he showed her the draft section about her and let her fact-check it and comment on it (Bailey, 2006a; p.e.c.'s Bailey to Dreger, August 22, 2006 and November 21, 2006). Although she did not dispute the basic details about her life, she was upset that he was using her as an example of autogynephilia (Bailey to Blanchard, p.e.c., December 2, 1998; Bailey, 2005). So Bailey told her that he would change her name in the book (Bailey, 2005; Kieltyka, 2006c).

Relations between Kieltyka and Bailey remained relatively cordial after she saw the manuscript; this is supported by records of friendly toned emails and by the fact that Kieltyka kept willingly presenting to Bailey's class and otherwise associating with him. The friendly association kept up even after Bailey publicly labeled Kieltyka an autogynephile in no uncertain terms in early 1999 in an interview for the article that appeared in the Daily Northwestern on February 24, 1999. As mentioned in Part 1, that article featured the stories of Kieltyka and her friend Juanita. The author, Maegan Gibson, one of Bailey's former Human Sexuality students, enjoyed the benefit of the full cooperation of Kieltyka and Juanita, and thus she was able to report key features of their histories and romantic lives. With their permission, Gibson's article also reported Kieltyka's and Juanita's real pre- and post-transition first and last names and reproduced before and after transition photos - that is, photos of their faces from the time when they were legally and socially men along with present-day photos from their lives as women. When Gibson interviewed Bailey for the article, he explained to her that he was writing a book and that he saw Kieltyka as an example of autogynephilia and Juanita as an example of homosexual transsexualism. And 
Gibson (1999) reported just that, as well as Kieltyka's clear objection to Bailey's classification of her.

Bailey did not formally interview Kieltyka for the book, though, as mentioned above, he did run a draft past her and she helped him fact-check and augment it (Bailey to Dreger, p.e.c., August 22, 2006). At no point did Bailey feel he needed to formally interview Kieltyka, given how much he already knew from her many class-related presentations and her extensive conversations and "show and tells" with him. As time went on, what he believed he knew about her was only confirmed over and over again in what she told him "in class, in my office, in restaurants, everywhere" (Bailey to Dreger, p.e.c., August 22, 2006). It was further confirmed by her published interview with Gibson in 1999 and her substantial participation in 2002 in a video made to accompany a human sexuality textbook. In that video, in which through Bailey's introduction Kieltyka participated voluntarily and for which she signed a full release to the publisher, she appears with her face unobscured, identifies herself as Charlotte Anjelica, tells her pre- and post-op story, and shows the prosthetic vulvas and female masks she used when she was Chuck (Allyn \& Bacon, 2004)

For the book project, Bailey did rather informally interview two of the supposedly homosexual transsexual women he had met through Kieltyka, those identified in the book as Juanita and Alma. He let them know he was writing a book, and they met with him and talked with him about their experiences. Some of what he wanted to write about them he already knew simply from meeting them socially through Kieltyka, but he used the follow-up conversations to confirm details (Bailey to Dreger, p.e.c., November 21, 2006). Kieltyka (2006a) has contended that Bailey also drew on what he could have only learned from the SRS letter interviews. Bailey disagrees: "I never used the information that I got in those limited interviews for the book" (Bailey, 2006a). (This is discussed in detail in Part 5.)

Some may well wonder why Kieltyka developed and maintained such a friendly association with Bailey when he persistently subscribed to a theory about her identity that conflicted with her own understanding. And why did it take so many years for her to get so upset about his characterization of her that she would turn on him? This is discussed more fully in Parts 4 and 5 below. For now, let me just say in summary that Kieltyka has explained to me that she valued her relationship with Bailey, and, though she knew he consistently labeled her autogynephilic, she thought that over time she could educate Bailey about her own theory of transsexualism and change his mind with regard to his understanding of it and her. Indeed, when Kieltyka had first learned that Bailey was writing a book on the subject, she was glad she would be included and excitedly imagined that it would be something of a collaboration in which he would explore Kieltyka's ideas, including her analogy between the role of sexual fetishes in transsexual transformation and the role of animal-part fetishes for similarly profound spiritual transformation in Native American rituals. (Kieltyka did not understand how this analogy would be seen as an offensive cultural appropriation to many Native Americans, including many Two Spirits.) She thought if she worked with Bailey long enough, she could get Bailey to understand (and write about) how gender identity, sexual orientation, and sexual identity could all be understood as distinct components of transsexual identity, and how fetishistic crossdressing could function as a stage of discovery and empowerment on the way to full transition (Kieltyka, 2006c, 2006d).

So, when Kieltyka saw the book draft in November 1998, she discovered - and was upset to discover - that Bailey was using her in the book as an illustration of autogynephilia. She recalls, "I felt trapped. But then he said this is a first draft, we can use any information to support your theory if you have support for your theory. If you can change my mind, that's all part of our relationship[.... What I saw was a misunderstanding or a misinterpretation, [and] I wanted the opportunity to change his mind" (Kieltyka, 2006b). Surely Bailey did see Blanchard's theory as a theory, but it seems to have held (and to hold) in his mind the sort of weight that the theory of universal gravitation does. That is because of what Bailey sees as the substantial scientific and clinical evidence for Blanchard's theory. It would take quite a lot of scientific counterevidence - far more than Kieltyka could muster - to displace it. Indeed, the more Kieltyka told and showed Bailey, the more she seemed anecdotally to confirm Blanchard's theory (Bailey to Dreger, p.e.c., August 22, 2006; Bailey, 2005). Kieltyka's yearly presentations, the transwomen she introduced Bailey to at Northwestern and at local bars, the interviews with Gibson-all these seemed to Bailey only to reconfirm what he felt he already knew from the scientific literature - that all transsexual women fit easily into one or the other of Blanchard's two types (Bailey, 2005). Kieltyka and her friends seemed like obvious examples of the two types, and, as he worked on his book, he saw them as just that: perfect illustrations to use in the book.

As do a lot of researchers, as Bailey went through his daily personal and professional life, he was making mental note of other people he met who did or didn't match various theories he had come across in his work-including people who could put a human face on the other sexual varieties and sexological concepts he wanted to talk, teach, and write about. Other characters that made it into his book include: Edwin, a very effeminate gay man who worked at the cosmetics counter of a department store near where Bailey lived; Leslie Ryan, a mother who came to Bailey with her questions and concerns about her son Danny who often behaved very girlishly; Ben, "the leader of the 'gay guys panel' who [like Kieltyka] spoke to [Bailey's] human sexuality class" (Bailey, 2003, p. 63); and Stephanie Braverman, a middle-aged heterosexual 
crossdresser who (like Kieltyka) after encountering a media report on Bailey's work contacted him "to "educate" him (Bailey, 2003, p. 160)

And, as a sex researcher with an active program, Bailey was doing scientific studies, the results of some of which would make it into his book. For example, he and his collaborators were looking at the occupations and avocations of gay men, the speech patterns of gay and heterosexual men and women, and the relative prevalence of feminine traits in gay men, drag queens, and MTF transsexuals (see, e.g., Barlow, 1996). These scientific studies were conducted with the approval of Northwestern's Social Sciences IRB, the committee charged with overseeing this type of human subjects research. (Which kinds of research require IRB approval is discussed in depth in Part 5.)

In the fall of 2002, Bailey submitted the final version of his manuscript to Joseph Henry Press, and in spring of 2003, the book came out in print and on the Website of the press (Bailey, p.e.c., October 5, 2006). The back cover of the print version included the following advance blurb from Harvard University psychology professor Steven Pinker:

With a mixture of science, humanity, and fine writing, $\mathrm{J}$.

Michael Bailey illuminates the mysteries of sexual orientation and identity in the best book yet written on the subject. [TMWWBQ] may upset the guardians of political correctness on both the left and the right, but it will be welcomed by intellectually curious people of all sexes and sexual orientations.

Meanwhile, psychology professor David M. Buss of the University of Texas opined: "Refreshingly candid, remarkably free of ideology, this book is destined to become a modern classic in the field. But readers should be prepared to have some cherished assumptions about human nature shattered." Anne Lawrence, physician, sexologist, and self-identified autogynephilic transsexual woman, remarked simply, "This is a wonderful book on an important subject." Needless to say, not everyone would agree. Nevertheless, as his book went to press, Bailey saw no hint that several of the transwomen with whom he had such good relations would, within just a few months, decide to turn against him.

\section{Part 3: What $T M W W B Q$ Actually Said}

If one is to understand the history of the controversy surrounding J. Michael Bailey's book, one must know what the book itself said, even though (as I will show) some of the reactions to $T M W W B Q$ were based on incorrect assumptions about the book rather than its actual content. The analytic synopsis presented in this section reviews the contents of $T M W W B Q$ relevant to this history-i.e., chiefly the portions on GID and transsexualism-while simultaneously making special note of which parts (real and imagined) drew particular ire. Let me be clear that the following synopsis is not intended as a substitute for an actual reading of $T M W W B Q$. In researching this history, I was dismayed to discover how many people_-including professional scholars_-were ready to give me detailed opinions about the book while admitting they hadn't bothered to read it. I think it is fair to say, and I hope here to show, that $T M W W B Q$ is an odd book in many ways, one that frequently doesn't do what you expect of it. Indeed, an examination of Bailey's collected works suggests this is generally true of his productions - they often don't match one of the standard, expected viewpoints - and I think this helps to explain a lot of the criticism he encounters from both progressives and conservatives who tend to adhere to clear-cut dichotomies of "facts" and opinions.

It is worth noting that a fair number of people were angered by Bailey's book before they ever even opened it. This was because of the cover, which features a black and white photo of the bare legs of a hairy, muscular man (shown from behind, from the knees down) standing, in a feminine pose, in pretty pumps. The book's title is superimposed on this picture. When I talked with him about the backlash against the book, Paul Vasey recalled being with Joan Roughgarden, a prominent transgender scientist, in February 2003 when she saw for the first time the book's cover, reproduced on a flier. Vasey remembers that, upon seeing the flier, Roughgarden immediately denounced the book and declared it a threat to the LBGT community (Vasey, p.e.c., July 3, 2006). Roughgarden could not have actually known what the book said, because it wasn't yet published (Vasey to Dreger, p.e.c., February 27, 2007). Just after the book was issued, in her blog, Becky Allison, M.D., a prominent transwoman, asked rhetorically, "Did I mention the cover art? A pair of big hairy legs in high heels. Are we having fun yet?" (Allison, 2003). On her Website, Andrea James remembered, "I winced the moment I saw Bailey's condescending title and cover art" (James, 2003a). Time after time, those I talked to about the book reported that the cover photo and title had immediately offended them or others. Even some of those generally friendly to the book found the cover a detriment. Bailey showed me an email from a stranger, a selfidentified feminine gay man, who in a thoughtful email message in May 2003 said he "was put off by the title and cover, thinking it unlikely to be a serious study. [...] The cover and title do not do your fine work justice, in fact they work against you" (p.e.c. to Bailey, May 13, 2003). Even Blanchard told me, "I didn't like the cover. Mike sent me the two choices [before publication] that I believe he got from the publisher. My recommendation was to go with the one he didn't take" (Blanchard, 2006), namely a cover featuring three very similar faces, with one looking masculine, one feminine, and one androgynous. 
Even though $T M W W B Q$ is about a lot more than MTF transsexualism, and even though Bailey insists the cover and title were meant to allude to a whole range of people who might fit under the umbrella of "feminine males," most critics (and indeed most readers) seem to have understood the cover and title to constitute a pejorative comment on transsexual women. Indeed, $T M W W B Q$ 's title and cover explicitly contrasted with those books on transgenderism which adhered to the "woman trapped in a man's body" narrative of transgender identity, or what I will call hereafter the "feminine essence" narrative. The feminine essence narrative is summed up by Bailey this way:

Since I can remember, I have always felt as if I were a member of the other sex. I have felt like a freak with this body and detest my penis. I must get sex reassignment surgery (a "sex change operation") in order to match my external body with my internal mind. (Bailey, 2003, p. 143)

In keeping with their themes, books that favor the feminine essence narrative have tended to feature on their covers attractive head-to-toes photos of transwomen dressed relatively conservatively. Consider, for example, the front cover of Deirdre McCloskey's Crossing: A Memoir, which shows a photo of the author dressed in dark suit (matching skirt and jacket) and pearls, seated with her legs crossed the way women often cross their legs, leaning back and laughing with both hands clasped to her upper chest (McCloskey, 1999). Even Kate Bornstein's Gender Outlaw: On Men, Women and the Rest of Us, which presents a somewhat radical account of a trans life, has as its cover illustration a photo of the author dressed in a long dress with long sleeves, her hands laid flat, wrists crossed, just above her breasts, rather like a butterfly (Bornstein, 1994). Contrast the subject of Bailey's book's title (The Man...) and cover illustration (a hairy, muscular man). Bailey's point seemed clear: the man who would be queen was really just a guy in size-thirteen pumps.

Those who, on the basis of his book's cover and title, suspected Bailey of rejecting the feminine essence narrative and who did bother to venture into the actual content of the book quickly found their suspicions confirmed. In the Preface, Bailey bluntly insists that eroticism, not gender identity, is the salient point in MTF transsexualism: "One cannot understand transsexualism without studying transsexuals' sexuality. Transsexuals lead remarkable sex lives" (Bailey, 2003, p. xii). He then provides a thumbnail foreshadowing of Blanchard's taxonomy of homosexual and autogynephilic MTF transsexualism: "Those who love men become women to attract them. Those who love women become the women they love" (p. xii). Convinced he's dealing with a fundamentally sexual phenomenon, Bailey shows no patience for the idea of women trapped in men's bodies; he out-and-out denies the feminine essence narrative told by many transwomen and pushed by therapists such as Ettner and Brown:

Supposedly, male-to-female transsexuals are motivated solely by the deep-seated feeling that they have women's souls. Furthermore, the fact that some transsexuals are sexually attracted to men and others to women allegedly means that sex has nothing to do with it. However, in this case the exception proves the rule. Heterosexual men who want to be women are not naturally feminine; there is no sense in which they have women's souls. What they do have is fascinating, but even they have rarely discussed it openly. (p. xii)

His book, he insisted, would be different. He would blast past the feminine essence narrative to the core truth of transsexualism: "[W]riters have been either too shallow or too squeamish to give transsexual sexuality the attention it deserves. No longer" (p. xii). So where MTF transsexualism was concerned, Bailey would happily play Galileo to Blanchard's Copernicus, spreading, supporting, and fiercely defending a truth too often denied and suppressed because of self-serving identity politics.

Given Bailey's lightning-quick summary of Blanchard's theory in the Preface, and given that Blanchard's taxonomy is not really spelled out clearly until page 146 , the reader unfamiliar with the concepts of "autogynephilia" and "homosexual transsexualism" — and plenty familiar with the female essence narrative-may well find $T M W W B Q$ a confusing book on the first pass. At least this reader did. After all, the first third of the book seems to carefully document what amounts to a feminine essence story. Part 1 (Chaps. 1-3), entitled "The Boy Who Would Be Princess," tracks a boy Bailey calls Danny Ryan, an anatomically typical, prepubescent male diagnosable with GID.

In Bailey's account, Danny seems to have had fairly feminine behaviors and interests from the very start (Chap. 1). Again in keeping with the standard feminine essence narrative, Bailey speaks unfavorably of psychological theories that would point to the Ryans' parenting as the source of Danny's femininity, hinting instead that, given how early and consistently it showed up, Danny's femininity is probably inborn. To further make the case for biological etiology of gendered behavior and interests, in his general discussion of Danny, Bailey uses outcomes studies of sex-reassigned children to suggest that the tendency towards what we ultimately call gender is at least in many cases set before birth (Chap. 3). In short, Bailey seems to see the tendency towards masculine or feminine behaviors and interests as largely innate-and thus "gender identity disorder" (or at least early-onset mismatches between sex and gendered behavior) as largely innate.

But in a sign of his turn away from the standard feminine essence story of transgenderism-that holds that girlish male 
children are really girls-Bailey sees as very important the fact that Danny's uncle is gay and, like Danny, was feminine from an early age (pp. 12-13). Thus, Bailey strongly suggests that being a feminine boy and becoming a gay man are correlated, and that they share a common biological etiology. Indeed, Bailey refers to data showing that nearly all boys like Danny diagnosable with GID turn out not to be transsexual women, but to be gay men (pp. 17-20). Given the outcomes data on boys treated for GID, and given the self-reports of gay men with regard to their childhoods, Bailey speculates that Danny will end up a non-transsexual gay man (pp. 17, 34). This, of course, is part of what infuriated certain trans critics who adhere to the feminine essence story of MTF transsexualism-especially those who are attracted to women; they wanted to claim personal histories just like Danny's, yet here was Bailey saying, in fact, that the vast majority of boys like Danny would just end up as fairly run-of-the-mill feminine gay men.

Still, at this point, the reader relatively new to the topic may wonder why Bailey would deny the feminine essence explanation to men who, as adults, do choose to change sex. Could they not have been, as they often claim, Dannys as children? After all, Bailey acknowledges that a very small number of boys with GID wind up to be transsexual women (pp. 19-20). Furthermore, he notes that outcome studies of boys treated for GID may be disproportionately missing those who did end up transsexual, "So maybe transsexualism is a more common outcome than some people believe" (p. 32). Why, then, would Bailey be reluctant to accept the claim of many transsexual women who say they have "always felt as if I were a member of the other sex" (p. 143)?

Interestingly, a close reading of Bailey's book reveals the author's persistent skepticism about many scientists' and clinicians' conception of gender identity, and an especially strong skepticism about the idea of an innate gender identity: " 'Gender identity' [in the psychological literature] refers to the subjective internal feeling that one is male or female" ( $p$. 22). But, Bailey insists, "most of us rarely, if ever, think about our gender identities" (p. 22). Most of us don't go through our days with an articulated sense of being male or female, the way the psychological literature (including the DSM) would lead us to believe. While he acknowledges that we all-as children and adults-seem to have gendered interests and gendered behaviors, Bailey is doubtful that young children have "subjective internal feeling[s] that one is male or female" (p. 22). He asks, "how would a girl even know if she had the same inner experience as a typical boy?" (p. 50). Ultimately, Bailey concludes that "scientists have not fully appreciated how complicated a trait gender identity likely is, or how little we know about it. One expert told me, bluntly: "Gender identity is defined as "the inner sense of oneself as male or female.' What the hell does that mean?" (p. 50). It makes more sense to him that children naturally exhibit "feminine" and "masculine" behaviors and interests, and that those are then categorized as feminine and masculine in such a way that children get the idea that they count as girlish or boyish.

So his doubt about the commonly held concept of a core gender identity is one reason Bailey remains dubious about claims by transsexuals that they change sex because they have always had a core gender identity that conflicted with their anatomical sex. He does, following Blanchard, acknowledge that "homosexual transsexuals" may be born with something like a neurological intersex - a kind of inborn feminized brain in a masculine body, so that from an early age they naturally exhibit feminine interests and behaviors: "From soon after birth, the homosexual male-to-female transsexual behaves and feels like a girl" (p. 146). Thus, Bailey distinguishes homosexual transsexuals from "autogynephiles" when he singles out the latter kind of MTF transsexual as "not naturally feminine" and in "no sense[...] hav[ing] women's souls" (p. xii). But still, he just doesn't think it is a gender identity problem that ultimately motivates people to change sex, even in the case of extremely feminine homosexual transsexuals: "Homosexual transsexuals are in their own way just as sexually motivated [to seek SRS] as autogynephiles" (p. 180).

"Princess Danny," then, is used by Bailey not as an example of transsexualism - and certainly not as an example of the feminine essence origins of transgenderism - but rather to show that some boys are really quite feminine, that this is probably caused by something that happens before birth, and that these boys will mostly likely wind up gay. Indeed, in his final story about Danny, presented in the book's Epilogue, Bailey portrays Danny as gay and very much "not a girl in boy's clothing" (p. 214) and when I asked Bailey whether he knows about Danny's identity today, he informed me, with little surprise in his voice, that Danny is now, in fact, out as a young gay man (personal communication, November 5, 2006). Thus, to Bailey, the story of Danny enables a discussion of how gendered behavior and gendered interests are often linked to sexual orientation-how it is that being gay often goes with being feminine in interests and behaviors. This explains why it is that, although many trans critics saw the story of Danny (Part 1 of the book) as comprising an integral part of Bailey's story of transsexualism, Bailey insists he doesn't really discuss transsexualism in depth until Part 3 of the book. The way he indexed the book confirms this; the index entries on transsexualism are almost entirely limited to the pages of Part 3.

So Bailey was rejecting the dominant (feminine essence) narrative of MTF transgenderism, and simultaneously rejecting the two dominant narratives of sex and gender identities, namely biological determinism and social constructivism. Or at least he was rejecting the standard versions of these theories. Biological determinists have tended to be fairly dualist (rejecting of gradations) with regard to gender; they assume two sexes 
means two genders. Meanwhile, social constructivists have tended to talk about spectra of gender identities, believing that cultural variation leads to variations in gender identities. Given these two dominant narratives about sex and gender, a number of critics assumed that, if Bailey was rejecting the feminine essence narrative of transsexualism, he must be collapsing gender identity and sex-that is, he must be a biological determinist who assumes that, if you're born genetically male, your gender identity will clearly be masculine (in spite of whatever you ultimately claim). You might put on pretty pumps, but you're not kidding anyone. Although Bailey leans heavily towards a biological understanding of the origins of gendered behaviors, gendered interests, and sexual orientation, his account is not about two simple gender identities that map to two simple sexes. In fact his book is largely dedicated toeven arguably all about - the

under-appreciated complication[...] that gender identity is probably not a binary, black-and-white characteristic. Scientists continue to measure gender identity as "male" or "female," despite the fact that there are undoubtedly gradations in inner experience between the girl who loves pink frilly dresses and cannot imagine becoming a boy and the extremely masculine boy who shudders to think of becoming a girl. (p. 50)

Bailey sees particularly in feminine gay men, many of whom were feminine boys, plenty of evidence that gender is not a one-or-the-other proposition.

In $T M W W B Q$ as elsewhere, Bailey rejects social influence explanations of gendered behaviors and sexual orientationsi.e., he rejects the idea that upbringing can cause certain boys to act like girls or to turn out gay. For example, he says, "There is no reason to believe that we could alter Danny's future sexual orientation even if we tried" (p. 20). Later he adds, "Essentialists believe that sexual orientation is an essential part of human nature. I am an essentialist" (p. 126). But Bailey does see a role for culture in our experiences of identity. He recognizes that boys and men who are homosexual or otherwise gender atypical can be made extremely miserable if they are prohibited from expressing their homosexuality and femininity (pp. 25-28). He acknowledges that, "In our world very feminine boys must contend with peers who despise sissies, fathers who get squeamish seeing them pick up a doll[....] For the most part, people do not just keep their attitudes to themselves but convey them to the boys" (p. 33).

With this comes an acknowledgment that more boys like Danny might become transsexual given a different cultural milieu:

Imagine that we could create a world in which very feminine boys were not persecuted by other children and their parents allowed them to play however they wanted[....] As much as I would like to arrange such a world, I think it might well come with the cost of more transsexual adults. Maybe it would be worth it, though. It is conceivable to me that transsexuals who avoided the trauma and shame of social ostracism and parental criticism would be happier and better adjusted than the gay men whose masculinity came at the expense of shame and disappointment. [...] I can imagine that this world would be more humane than ours. (p. 33)

Similarly, Chapter7, "Is Homosexuality a Recent Invention?", rejects the idea that sexual orientation is simply socially constructed, but in his examples Bailey also makes clear that he understands that cultural setting strongly influences how one will live out one's orientation. So he claims, "Transgender homosexuality is probably the most common form of homosexuality found across cultures" (p. 134). He defines this as "occur[ing] when one man takes on a feminine role, often dressing as a woman and taking a woman's name, and [having] sex with masculine men" (p. 134). He sees this basic phenomenon-ultra-feminine homosexual males-as showing up in part because certain cultures tolerate it, but also because of biological variation that exists consistently throughout the human population: "The cross-cultural regularity of homosexual transsexuals and drag queens is highly suggestive of some fundamental biological influence that transcends culture" (p. 136). Culture constrains and/or amplifies what arises naturally.

Thus, while two common misperceptions are that Bailey rejects any idea of innate transsexuality and that he rejects any idea of culture mattering, in fact he's placing what is called MTF transsexuality (the desire to change sex from male to female [p. 144]) on a spectrum of biologically induced male sexual variation, a spectrum that in our culture includes the people who are ultimately identified as feminine gay men, transvestites, drag queens, and transsexuals. Who lives out which role depends on the interaction of each individual's biology, experience, and cultural milieu. This might again, to the novice, sound like a theory most trans people would welcome. But, in fact, it again involves a rejection of the standard feminine essence narrative; that is, it rejects the idea that some people are born "true transsexuals," profoundly different from all other people in having the true gender identity of one sex in the body of the other. It also means crossdressers (whom Bailey claims are also erotically motivated) are not that different from the non-homosexual transsexuals_- "They are all autogynephiles" (p. 164) —an idea really irritating to many transwomen who do not see themselves as autogynephiles and who sometimes see themselves as "true transsexuals" distinguishable from (and much more normal than) crossdressers. So, the fact that he speculates that 
autogynephilic transsexuals, like homosexual MTF transsexuals, are essentially born, not made (pp. 169-170), would placate few transwomen who reject the idea that eroticism motivated their SRS or that they are in league with fetishistic crossdressers.

Although he is generally pessimistic about social progress- "Who can really hope to change society?" (p. 28)Bailey also actively argues (progressively, I think) that there's nothing really wrong with being a feminine male or a gay man, or, as he thinks is often the case, both. He sees as simple truths-simple truths well supported by scientific researchthat gay men are more likely than straight men to enter certain feminine-identified professions and have feminine-identified interests (pp. 63-69), that gay men are more likely than straight men to remember acting or being identified as feminine as children (pp. 62-63), and that gay men are more likely than straight men to walk, stand, and sit more like women (pp. 73-76). He admits "that not all gay men are alike, and not all straight men are alike, and some gay men are very much like straight men (except, by definition, in their sexual orientation)" but he adds that this "does not invalidate the fact that there are some large differences between typical gay men and typical straight men" (p. 64). In Bailey's view, critics who wrongly call him homophobic for noting these "stereotypes" are themselves just femiphobic-homophobic by virtue of being afraid and intolerant of femininity in men, which he suggests he is not (p. 59).

But Bailey's tone with regard to transsexuals seems to be notably less tolerant - or at least significantly more uneven. It is not true, as some critics claim, that he denies transwomen their female identities by using the male pronoun to refer to post-transition women; in fact he consistently uses the same convention used by others like Deirdre McCloskey in her autobiography: "he" for pre-transition, "she" for post. Indeed, Bailey uses "she" as soon as a social gender transition happens, even if a woman has not had SRS (see, e.g., Bailey, 2003, pp. 149, 155). Nor, as noted above, does he deny the claim that transsexualism might be inborn; autogynephilic transsexualism like homosexual transsexualism "smells innate" to him (p. 170).

But there seems to be plenty else in the book to offend many transwomen and their allies. First, there is the running theme started in the Preface of the feminine essence narrative being a sometimes-willful lie told to cover up a sexual fetish, namely autogynephilia, and the associated theme that virtually all "non-homosexual transsexuals" are autogynephilic, no matter what they claim about themselves and their histories. Bailey says that autogynephilic transsexuals "sometimes misrepresent themselves as members of the other [type of transsexual... T]hey are often silent about their true motivation and instead tellstoriesaboutthemselvesthataremisleading and,inimportant respects, false" (p. 146; cf. p. 173). To further emphasize how deceptive he thinks most non-homosexual (i.e., autogynephilic) transsexuals are, he praises "Honest and open autogynephilic transsexuals [who] reveal a much different pattern" of gendered history than homosexual transsexuals (p. 147). He quotes transwoman Maxine Petersen, "the ace gender clinician at the Clarke," as saying "Most gender patients lie" about the erotic components of their feelings and desires so that they can obtain the sex changes they reasonably fear they will otherwise be denied (p. 172). (Bailey implicitly admits this fear is wellfounded: "some psychiatrists refuse to recommend for sex reassignment any man who has had even one incident of erotic cross-dressing" [p. 174].) One gets the clear sense from the book that all transsexual narratives are deeply suspect — or just plain false - unless they fit Blanchard's theory and Bailey's reading.

Bailey also speaks of transsexuality as being something for which a boy may be "at risk" suggesting it is a relatively bad outcome (see, e.g., pp. 30-31). His logic spins out this way: " $[\mathrm{S}]$ ex change surgery is major and permanent, and can have serious side effects. Why put boys at risk for this when they can become gay men happy to be men?" (p. 31). He also points to the possibility that autogynephilic transsexuals "might dedicate their lives to changing their sex to the point of apparent obsession, losing families, friends, and jobs in the process" (p. 144). The implication: best that these "risks" be minimized if possible. I think it is safe to say that few trans adults see their identities as a risk to be avoided, any more that most natal women see their identities this way, even though being a natal woman (like being a transwoman) invariably comes with biological and social challenges.

In parts of the book, Bailey talks more bluntly about transsexuality as if it is a disease, or at least a disorder: "I suspect that both autogynephilic and homosexual gender dysphoria result from early and irreversible developmental processes in the brain. If so, learning more about the origins of transsexualism will not get us much closer to curing it" (p. 207; emphasis added). He particularly singles out the nonhomosexual transsexuals as having a paraphilia, namely autogynephilia:

Paraphilias comprise a set of unusual sexual preferences that include autogynephilia, masochism, sadism, exhibitionism[...], frotteurism (rubbing oneself against strangers[...]), necrophilia, bestiality, and pedophilia. Because some of these preferences (especially pedophilia) are harmful, I hesitated to link them to autogynephilia, which is not harmful. But there are two reasons to think that these sexual preferences have some causes in common. First, all paraphilias occur exclusively (or nearly exclusively) in men. Second, paraphilias tend to go together. [... A]lthough most autogynephiles are not sexual sadists, they are more likely to be sadists compared with men who are not autogynephilic. (pp. 171-172) 
In this way, Bailey's portrayals of transsexuals often do not strike the average reader as flattering, even when he may intend them to be such or to be merely descriptive. He argues that "True acceptance of the transgendered requires that we truly understand who they are" (p. 176), but who he says they truly are seems unlikely to lead to general acceptance.

For instance, how many already-transphobic people would be inclined to be more accepting upon hearing from Bailey about the high rate of sex work, promiscuity, and petty theft among "homosexual transsexuals"? Bailey generalizes, "Most homosexual transsexuals have also learned how to live on the streets. At one time or another many of them have resorted to shoplifting or prostitution or both. This reflects their willingness to forgo conventional routes, especially those that cost extra time or money" (p. 184). He says of Juanita, "her ability to enjoy emotionally meaningless sex appears male-typical. In this sense, homosexual transsexuals might be especially well suited to prostitution" (p. 185). Even when he lists other occupations among transsexual women, the list is limited to fairly low-status professions: they work as "waitresses, hairdressers, receptionists, strippers, and prostitutes, as well as in many other occupations" (p. 142).

Bailey's portrayal of autogynephiles (by his schema, all MTFs except classic homosexual transsexuals) also seems unlikely to cause an outpouring of admiration or acceptance from the rest of the population, especially as he speaks of them (using physician, sex researcher, and transwoman Anne Lawrence's phrase) as "men trapped in men's bodies" (Chap. 9). He himself admits that autogynephilia is so "bizarre to most people" and "differs so much from ordinary experience that it cannot be understood simply" (p. 166). After all, "Autogynephiles are men who have created their image of attractive women in their own bodies, an image that coexists with their original, male selves. The female self is a manmade creation" (p. 168).

$T M W W B Q$ includes two vivid portraits of supposed autogynephiles, and it is really not surprising that the two portraits are not the sort many transwomen want to publicly identify with. They both seem sexually strange, and perhaps pathetic. The first is of "Stephanie Braverman," a "50-ish married man" crossdresser (p. 160), who "insists [to Bailey] that the primary benefit of cross-dressing these days is relaxation" ( $p$. 161), a claim Bailey doesn't believe for a second. Given Braverman's history of masturbating while cross-dressed, and given her confessed fantasy that Bailey "would treat her "like a lady' - take her out to a nice restaurant and then out dancing" (p. 165), Bailey considers her a rather classic autogynephile.

The second supposed autogynephile represented in the book is included "less because she is representative than because she openly and floridly exemplifies the essential features of [...] autogynephilia" (p. 156). This is Bailey's account of Anjelica Kieltyka, identified in the book's account of her as Cher Mondavi, né Chuck Mondavi. In $T M W W B Q$, details from Kieltyka's history allow Bailey to paint a portrait of the autogynephile as a young man and child-boyish, apt to experience occasional unexpressed wishes to be a girl, and prone to masturbating while crossdressed or while fantasizing about being a woman. Because it illustrates the phenomenon of autogynephilia, Bailey goes into particular detail about "a period in Chuck's life marked by a devotion to cross-dressing that was both obsessive and highly creative" (p. 153). This was the period that included the use of prosthetic breasts, vulvas, wigs, and female masks, and the period that involved the production of the pornographic video Kieltyka showed to Bailey and his many students. Bailey notes that Chuck also

constructed a "robot man" that could fulfill the fantasy of penetration. "Robot man" had a body, a penis made of a dildo, and even an arm that Chuck could manipulate to make it feel as if it was stroking his back. Chuck attached a mirror to his bedroom ceiling, and could view the image of the robot man on top of Chuck, dressed as a woman, "penis" in Chuck's anus. (p. 154)

Bailey goes on to tell of "Cher" being "born in 1991," a year before she got her SRS (p. 155). He relays Cher's insistence "that once Chuck became Cher, the sexual focus was no longer a self-image, but other people" (p. 156). But he doesn't think this claim exempts her from the category of autogynephilic transsexual. (Notably Kieltyka has never said Bailey got any of the details of her life story wrong in the book; her objections have been directed at his labeling of her as autogynephilic and his exclusion of her own understanding of what her history tells about her identity and about transsexuality.)

Bailey's remarks on the appearance of transwomen such as Cher are often germane to his discussion, but they too undoubtedly rubbed a lot of people the wrong way. Take, for example, this: "There is no way to say this as sensitively as I would prefer, so I will just go ahead. Most homosexual transsexuals are much better looking than most autogynephilic transsexuals" (p. 180). Bailey confirms this opinion when he describes his own sexual response (only) to homosexual transsexuals: "It is difficult to avoid viewing Kim from two perspectives: as a researcher but also as a single, heterosexual man" (p. 141). Later we read that, "When [Kim] came to my laboratory, my initial impression was reconfirmed. She was stunning. (Afterwards my avowedly heterosexual male research assistant told me he would gladly have had sex with her, even knowing that Kim still possessed a penis.)" (p. 182). His explanation of the appearance differential between homosexual and autogynephilic transsexuals points partly to homosexual transsexuals being born more feminine and more likely to transition early (i.e., before advanced masculinization), and partly to the sexual orientations that allegedly distinguish them: while homosexual transsexuals want to be able, post-transition, to attract heterosexual men, "The 
autogynephile's main romantic target is herself" (p. 183). Thus, the homosexual transsexual who will have trouble passing is less likely to decide to transition than the autogynephilic transsexual who is willing to struggle even postSRS with passing, since the former needs to pass for sexual gratification while the latter does not.

In keeping with his focus on the erotic motivations for SRS, Bailey's portrayal of individual homosexual transsexual women-including women identified as Terese, Alma, Maria, Kim, and Juanita-focuses on their sexual interests and activities. He sees "in important respects" the "story of all homosexual male-to-female transsexuals" in Terese's story: "Her early, extreme, and effortless femininity, her unambiguous preference for heterosexual men as sex partners, her (however brief) attempt to live as a gay man, and her difficulty in securing the right kind of guy prior to surgery, are almost universal among this type of transsexual" (p. 151). In contrast to his intimation about many autogynephiles, including Braverman, Bailey expresses virtually no skepticism about the stories of homosexual transsexuals, because they tell him stories consistent with his understanding of them. They confirm his presumption that they have male-typical high sex drives, high enough that they follow those sex drives even when it may not be in their apparent best interests. So he tells the story of Juanita who, finding herself bored and undersexed, separates from her husband and apparently idyllic life in the suburbs: "she missed the excitement of living in the city, and of dating new partners. She had also begun to work again as an escort-she had done this before meeting her husband" ( $p$. 210). Bailey takes the opportunity of this story to add, "Nearly all the homosexual transsexuals I know work as escorts after they have their surgery. I used to think that somehow, they had no other choice. [...]I have come to believe that these transsexuals are less constrained by their secret pasts than by their own desires[...] including the desire for sex with different attractive men" (p. 210).

One might assume from this sort of passage that Bailey negatively judges homosexual transsexuals, but in fact he doesn't seem to think there's anything wrong with their choice of sex work, their high sex drives, or their identities. Similarly, though he labels autogynephilia a paraphilia, he is clear that it is "not harmful" in the way some other paraphilias are (p. 171). And while his portrayal of Braverman seems to have a certain tone of exasperation, his portrayal of Kieltyka is overlaid with his appreciation of her talents as an artist and her struggles as an unconventional person:

I think about what an unusual life she has led, and what an unusual person she is. How difficult it must have been for her to figure out her sexuality and what she wanted to do with it. I think about all the barriers she broke, and all the meanness that she must still contend with. Despite this, she is still out there giving her friends advice and comfort, and trying to find love. And I think that in her own way, Cher is a star. (p. 212)

In this way, Bailey's portrayals of transwomen seem quite mixed in tone.

But there is one very interesting and important way in which Bailey is consistent in his consideration of transwomen: If one reads $T M W W B Q$ without presupposition, it's clear that Bailey measures long-term "success" for transwomen specifically in terms of whether or not they are happy. He leaves no doubt that individual transwomen's happiness is what researchers and clinicians (and presumably the rest of us) should care about: "Surely the most relevant data [on SRS] are transsexuals' own feelings before and after transitioning. Are they glad they did it? By now, hundreds of transsexuals have been followed after changing sex, and the results are clear. Successful outcomes are much more common than unsuccessful outcomes" (p. 207). The way Bailey tells the stories of individual women only confirms this. For example, he relays that "Terese has blossomed since her surgery. [...] Depressed and in self-imposed isolation when I first saw her, she is flirtatious, energetic, and socially busy now" (p. 150). The story of Cher (Kieltyka) comes out basically the same way: "for the most part Cher has been happier than Chuck was. She is more outgoing and feels that she lives a real life now, instead of a fantasy life. Despite her negative experiences with her family, many other people have accepted her" (p. 155).

Similarly, when he talks about how a different cultural milieu might lead more Dannys to become women, Bailey names as a "more humane [world] than ours" that which leaves more people "happier and better adjusted" (p. 33). When he talks about treatment options for boys with GID who come to Toronto psychologist Ken Zucker's clinic, he imagines a randomized control trial that would "see if those Zucker treats are less likely to become transsexual. Or see if the boys Zucker treats are happier in some other way" (p. 34). Thus, while he acknowledges that being transsexual might interfere with happiness - given the costs and risks of transition-he also entertains the possibility that outcome studies will show SRS (and thus fully realized transsexualism) provides the greatest chance at happiness for some people. Happiness for the individual transwoman is the goal, even if it means her family suffers from her transition: "I do not think that this real suffering [on the part of family members] should be used to discourage transsexuals from sex reassignment" ( $p$. 209).

Bailey's rejection of the feminine essence narrative has led a number of readers (and non-readers) to incorrectly assume that he has also rejected SRS. In particular, many I talked to assumed that, like psychiatrist Paul McHugh of Johns Hopkins University, Bailey thinks that having autogynephilia (considered a sexual disorder) should eliminate one from SRS candidacy. But, in fact, for autogynephilic as for homosexual 
transsexuals, Bailey believes that, if the subjects will be happier with SRS, they should seek and obtain it. Indeed, he takes McHugh to task for forcing transsexuals to continue suffering by denying them SRS. "Given our present state of knowledge, saying that we should focus on removing transsexuals' desire to change sex is equivalent to saying that it is better that they should suffer permanently from gender dysphoria than that they obtain sex reassignment surgery" (p. 207).

As I believe I have shown here, this book isn't simply proor anti-gay or pro- or anti-trans. It isn't simply socially constructivist or biologically determinist. It's significantly more complicated than it at first appears, and much more complicated than its cover and title would lead one to believe. Most importantly for this discussion, $T M W W B Q$ is not the book many people assumed it to be-particularly after the phenomenal backlash it received-nor is it the book many still claim it to be. But it is the book-real and imagined-that served as a flashpoint for the criticism and retaliation detailed in the next section of this history.

\section{Part 4: The Backlash}

It is clear from the historical record that many people reacted negatively to $T M W W B Q$ before (or whether) they had even read it and, in her initial email about the book to Andrea James, Lynn Conway revealed that to have been the case with her, too. Conway-who would essentially become the architectin-chief of the backlash-first sounded the alarm about $T M W W B Q$ to James on April 10, 2003:

I just got an alert about J. Michael Bailey's new book. It's just been published and of all places it's co-published by the National Academies Press, which gives it the apparent stamp of authority as "science" [...] As you may know, Bailey is the psychologist who promotes the "two-type" theory of transsexualism [.... Anyways - not that there is much we can do about this- but we should probably read his book sometime and be prepared to shoot down as best we can his weird characterizations of us all. (Conway, 2004a)

Why were people such as Conway so sure Bailey's book spelled trouble? Surely, the cover and the title had something to do with it, as did their longstanding rejection of Blanchard's theory. The fact that the book was a popularization directed at the masses - and not an obscure journal article — and that it had the imprimatur of the National Academy of Sciences reasonably added to the sense that it could have a substantial impact on how people would think about MTF transsexuals. In that initial email alert to James, Conway guessed, "Sadly, his book will probably become popular with people who 'want to understand us', and will seem sort of 'empathetic' towards us, but if it is at all like his past writings, it will treat us all as rather pathetic objects of study-and of course he calls us all 'transsexual men [sic]'" (Conway, 2004a).

In addition to all these concerns, I think it must also be the case that the extraordinarily strong reaction to $T M W W B Q$ had something to do with trans activists' knowledge of the long history of oppression against trans people — a history that has included criminalization, involuntary committal to mental institutions (as McCloskey learned firsthand [McCloskey, 1999]), denial of basic rights, active discrimination in housing and employment (as Conway learned firsthand [Hiltzik, 2000]), relentless harassment, mockery, and, not so infrequently, brutal assault and murder. And not just the murder of trans people themselves, but of their loved ones, too; the boyfriend of Andrea James's close professional collaborator, Calpernia Addams, was murdered when his fellow soldiers found out his girlfriend was transsexual (France, 2000). My own experience suggests that there isn't a single trans person who, when asked, can't immediately recall instances of being concerned for her or his personal safety, job, lover, or family. Add to this the sense among many trans people that they have had their identities unnecessarily medicalized and pathologized, and the sense among many trans activists that they have been denied sympathy from and alliance with other queer rights leaders and feminists. (It's not uncommon to hear trans critics of Bailey's book liken it to Janice Raymond's The Transsexual Empire, a book which accused transsexuals of undermining women's rights and actively harming women with their supposed naive adherence to sexist ideas about what it means to be a woman [Raymond, 1979].) Given all this, it is not too surprising that people such as Conway would have been-as her early emails suggeston high alert for possible new threats.

Yet, even with an understanding of this backdrop, it can be hard to fathom how the backlash against Bailey's book could have reached the proportions it did. Several people have remarked to me that the controversy over $T M W W B Q$ ultimately amounted to "a tempest in a teapot," but if that is the case, the teapot Bailey's detractors constructed grew to the size of a battleship.

There is a remarkable graphic on Andrea James's "tsroadmap" Website that evidences this. Let me say, before I describe this graphic, that I don't think this computer-generated image shows what James thinks it shows. She apparently thinks it proves the horrific scope of Bailey's supposedly antitrans claims and eugenical desires as revealed through the intensive "investigation" into Bailey that James and Conway co-led. I think the image reveals the depth and breadth the backlash against Bailey's book took on. Entitled "J. Michael Bailey Connections," the graphic in question purports to be "a diagram explaining the connections of all of the people in the Bailey-Blanchard-Lawrence investigation"-Bailey, Blanchard, and physician-researcher Anne Lawrence having been 
lumped together, by this point, by Conway and James as a single, uniformly dangerous beast for their active support of Blanchard's taxonomy. In the diagram, a stark black background dramatically offsets an elaborate blossom of colored bubbles, each showing some institution or field of inquiry that James apparently believes to be associated (mostly nefariously) with Bailey and his alleged anti-LBGT scheme. The bubbles are color-coded, and a key to the coding is helpfully provided: cyan is used to indicate theories and fields; purple is for universities (no doubt as a tribute to Northwestern University, whose school color is purple and who is the worst of all offenders, judging by the size of its bubble); gold is for government entities; and red is for "sexology trade group[s]." The last category includes the International Academy of Sex Research (IASR), the Society for the Scientific Study of Sexuality (SSSS), and the HBIGDA, a group now known as the World Professional Association for Transgender Health (WPATH). Names of individuals appear superimposed on their institutions' bubbles, and the names of all individuals and organizations are awarded font size commensurate with their importance in James's scheme. Thus, Bailey's and Kieltyka's names appear in a larger font, while, for example, the names of Eli Coleman and Walter Bockting (sex researchers at the University of Minnesota) appear in a smaller font (James, n.d.-a).

The central contention of this diagram is that "Bailey's theories and work as a pop psychologist are heavily informed by a combination of eugenics and sexology, put to work shaping public perception and policy of our community" (James, n.d.-a). The picture is thus presumably meant to capture how overwhelming and socially credentialed the forces against transwomen's rights seemed to be-how much the cards were stacked in Bailey's favor. Groups seemingly indicted by association with Bailey include the Kinsey Institute, the "National Academies of Science [sic]," and the "National Institute [sic] of Health." The fields of abnormal psychology, criminology, and evolutionary psychology are also called to task, as are a number of prominent sexologists, including, confusingly, several who have publicly criticized Bailey's book. The chart even features a few far-flung scholars who have told me they have no idea how they ended up in this picture. (I have explained to them the reasoning where I have understood it.) Looking at this graphic, I can see why in 2005-after 2 years of seemingly endless personal attacks, extreme accusations, and investigations-some of Bailey's sexology friends took to wearing $t$-shirts reproducing the graphic, as a sort of sympathetic joke. And I admit that, when Bailey showed me one of the t-shirts, seeing the graphic for the first time I assumed it to be a satire made up by an ally to cheer him up. I had no idea the graphic was real - that it was made by James herself and was meant to be serious.

The basic story of the florid explosion that is depicted by James and that I'm going to try to unpack goes like this:
Starting in April 2003, Conway and James spearheaded what they saw as a counterattack on Bailey's book. (I say "what they saw as a counterattack," because, although he understood his book would offend some people, Bailey never considered his book an attack [Bailey, 2006a].) Conway, James, and a group of allies used the power of the Internet and the press to try to undermine Bailey's professional reputation, undo any positive praise his book received, and make Bailey as personally miserable as possible. As they felt he had attacked them in the spaces of their public and intimate lives, they would try to do the same to him. Fairly early in the process, Anjelica Kieltyka (identified as "Cher" in $T M W W B Q$ ) joined forces with Conway and James. James-and Conway to a lesser extent — tended to take an "if you're not with us, you're against us" approach to their work. Thus, anyone who seemed to be on Bailey's side or refused to fully turn risked being labeled as part of the problem. This meant that even those who did not want to get involved often found it impossible not to be.

As I've learned from many hours of conversations with Anjelica Kieltyka, within a few months of the start of the backlash, the relationship between Kieltyka and the leaders of the "investigation" (including, by then, Conway, James, and Deirdre McCloskey) became strained. Kieltyka seems to have grown tired of Conway's and James's implicit message that she was to blame for a lot of Bailey's "abuse" of transwomen in Chicago because she had introduced him to those women and encouraged their interactions. As time wore on, Kieltyka also became personally adept at doing her own Internet searches. As a result of all this, Kieltyka increasingly became convinced that the real problem was much larger than Bailey's treatment of transsexuals - and thus, much larger than anything she might have enabled (Kieltyka, 2006a, 2006b; see also p.e.c. from Kieltyka to approximately 150 people, subject line "What's Wrong With This Picture-Scowcroft-Zeder-Conway???", September 2, 2005). Using clues she picked up from Bailey's other work-including an article he co-authored explaining how parental selection against offspring carrying a (theoretic) "gay gene" would not be inherently unethical (Greenberg \& Bailey, 2001)—Kieltyka became convinced that Bailey was part of a much larger, rightwing, international effort to alienate and even "screen gays out of existence" using emerging biotechnologies, including gesture-recognition software and genetic engineering. She recalls, "I began to see that there was collusion," and that, while Bailey's treatment of transsexuals was very important, "the gay issue was more important" (Kieltyka, 2006a).

James's graphic from October 2003 thus appears to make reference both to the "if you're not clearly with us, you're against us" general mentality of the perceived counterattack as well as Kieltyka's emerging conspiracy theory about Bailey and an international, anti-gay, biotech program. Conway, James, and McCloskey apparently remained relatively cool 
to Kieltyka's expansive theory; "they were surprisingly unimpressed" according to Kieltyka, and "it puzzled me but it did not discourage me" (Kieltyka, 2006a). She pressed on, although, to Kieltyka's dismay, Conway continued to resist pursuing and publicizing it. Eventually, this led Kieltyka to investigate Conway herself, and to become convinced Conway might actually be part and parcel of the international antigay program through her computer work; Kieltyka intimates Conway has developed technologies-including gesturerecognition software - that would support and thus profit from it (Kieltyka, 2006a; see also e-mail from Kieltyka to approximately 150 people, subject line "What's Wrong With This Picture-Scowcroft-Zeder-Conway???", September 2, 2005). Indeed, she believes there is "some possibility that Bailey was using this technology" in his "gaydar" research work "developed for Bailey by Conway and [Conway's former student Charles] Cohen" (Kieltyka, 2006a). What she found "finally made [her] think that [Conway] had a major conflict of interest and she was misdirecting this whole ad hoc trans investigation" into Bailey and his book (Kieltyka, 2006a). Kieltyka told me that nowadays she believes Bailey was just the "fall guy" in the scheme, a scheme in which Conway ranks much higher (Kieltyka, 2006a). The fact that Conway now refuses to speak to Kieltyka-and indeed recently accused Kieltyka of stalking her-only solidifies Kieltyka's sense that Conway is part of something she doesn't want Kieltyka and others to know about (Kieltyka, 2006a). But Kieltyka has pursued her inquiry, in spite of fear. She even called Cohen, Conway's former student and collaborator, to ask him about the gesture-recognition software; when Conway found out about this, she accused Kieltyka of trying to "out" her to her former student (Kieltyka, 2006a). (It's hard to imagine how Conway thinks she isn't "out," given that her university-based Website prominently features her cross-sex biography.) All this might sound crazy, petty, or amusing to some, but such a reading would minimize the actual damage done to people in the whole $T M W W B Q$ affair.

So how did the backlash start? Within a couple of days of her first alert to James on April 10, 2003 (quoted above), Conway read the book, and found herself as appalled as she had expected (Conway, 2004a). She immediately understood the text as especially dangerous because it was fully cloaked in the social power of science and academia. Thus, within just a few more days, Conway called to arms as many allies as she could, insisting

this book is the equivalent for the entire transgender community of a Ku Klux Clan [sic] smearing of the entire black community by painting their entire lives and identities as nothing more than the obsessive pursuit of bizarre sex. Imagine what would have happened if the Academy had published a book such as this about African Americans. Their gates would be stormed and the institution would fall. So how can they get away with doing this to us? They can't, unless we let them get away with it! (April 18, 2003, p.e.c. of Lynn Conway to Christine Burns, Joan Roughgarden, Sarah Weston, Emily Hobbie, Gwendolyn Ann Smith, Donna Rose, Susan Stryker, Jenny Boylan, Jamison Green, Stephen Whittle, and Shannon Minter; available at Conway, 2004a)

Conway officially opened an "investigation" into Bailey and his book and, along with Andrea James, started devoting a substantial amount of energy and Web presence to doing what they could to undermine Bailey and $T M W W B Q$. (I put "investigation" in quotation marks throughout this essay because, as I show, it quickly moved from an inquiry to something much more proactive.) A number of prominent trans scholars and activists immediately agreed with Conway that Bailey's book was serious trouble, and Conway rapidly posted many of their negative reactions (or links to them) on her University of Michigan site. Becky Allison, M.D., Joan Roughgarden, Ph.D., Ben Barres, M.D., Ph.D., Christine Beatty, and Christine Burns all provided expressions of disgust and dismay (see Conway, 2003a). Through fortunate timing, Roughgarden was able to attend a lecture by Bailey at her own university, Stanford, on April 23, 2003, and write a scathing review of it for the school newspaper (Roughgarden, 2003). The backlash against the book had thus begun in force.

Notably, not everyone in the LBGT world found $T M W$ $W B Q$ to be the moral and political equivalent of the pro- $\mathrm{Ku}$ Klux Klan film-fantasy "Birth of a Nation." After all, one of the blurbs on the book jacket came from Simon LeVay, a prominent gay scientist, and another from Anne Lawrence, a transwoman and physician (who subscribes to Blanchard's taxonomy and identifies herself as an autogynephilic woman). A reviewer for Lavender Magazine called the book "a highly readable and well-researched book. [...] Detailed, but never dry. A fascinating book" (Boatner, 2003) and a writer for Out Magazine declared the book "recommended reading for anyone interested in the study of gender identity and sexual orientation" (Osborne, 2003). In a review published by the Society for the Psychological Study of Lesbian, Gay, and Bisexual Issues - a division of the American Psychological Association-James Cantor, an openly gay sex researcher who works with Blanchard, opined that "Bailey sympathetically portrays these peoples' experiences[....] Bailey's respect for the people he describes serves as a role model for others who still struggle to accept and appreciate homosexuality and transsexuality in society" (Cantor, 2003; see also Velasquez, 2004).

Certainly not all LBGT reviewers praised the book; perhaps revealing the continued fractured politics between the " $\mathrm{G}$ " and the "T" communities, trans reviewers were much more likely than gay reviewers to criticize the book. Jamison Green (a transman) and Deirdre McCloskey (a transwoman) 
both panned it (Green, 2003; McCloskey, 2003a). Nevertheless, while the condemnation from Conway and those who joined her would come to suggest a unilateral denouncement of the book by all parties on the LBGT front, the reviews suggest otherwise. Positive reviews by queer people seem only to have made Conway and James angrier. Indeed, James was annoyed enough that she sought out writers of positive reviews and asked them to explain themselves, publishing their responses on her Website (see, e.g., James, 2003b).

Now, it's clear throughout the record of the backlash against $T M W W B Q$ that what Conway, James, McCloskey, Burns, and other involved transwomen leaders detested and rejected most about Bailey's book was the idea of autogynephilia. After all, in Bailey's presentation of Blanchard's scheme, women such as they might be labeled autogynephilic_-individuals with paraphilias whose cross-sex identification was not about gender but eroticism. Yet, I think it is worth noting that historically not all of these transwomen leaders had always rejected every shred of what might reasonably be classified as autogynephilia the way they would come to do post-TMWWBQ. McCloskey strongly denies that "autogynephilia" applies to her (and indeed recently informed my Provost she would sue me and my university if I dared to diagnose her with it [McCloskey to Dreger, two p.e.c.' s, copies to Lawrence Dumas, February 4, 2007]). But Bailey has pointed out that she does discuss in her autobiography a pre-transition arousability to the idea of becoming or being the other sex (Bailey, 2003, pp. 217-218; see also Rodkin, 2003), an admission that is hard to imagine her offering post-TMWWBQ. McCloskey is speaking here of Donald, her pre-transition self, in the third person:

When in 1994 he ran across A Life in High Heels, an autobiography by Holly Woodlawn, one of Andy Warhol's group, the parts he read and reread and was sexually aroused by were about Woodlawn's living successfully for months at a time as a woman, not her campiness when presenting as a gay genetic man in a dress. Donald's preoccupation with gender crossing showed up in an ugly fact about the pornographic magazines he used. There are two kind of crossdressing magazines, those that portray the men in dresses with private parts showing and those that portray them hidden. He could never get aroused by the ones with private parts showing. His fantasy was of complete transformation, not a peek-aboo, leering masculinity. He wanted what he wanted. (McCloskey, 1999, pp. 18-19; for McCloskey's response to Bailey's reading of this, see Rodkin, 2003 and McCloskey, 2003b)

Anne Lawrence also recalls that, before the blow-up over $T M W W B Q$, one of the other transwomen who would become part of Conway's expanded "investigation" team admitted to Lawrence that the way she finally achieved orgasm after SRS was to fantasize about forced feminization (Lawrence to Dreger, p.e.c., Nov. 28, 2006; see also Lawrence, 1998). And still a third member of the "investigation" team apparently for years had accepted the label of autogynephilia for herself and others. This was none other than Andrea James.

The evidence for this is unmistakable. In 1998, James had written to Anne Lawrence to congratulate her on her latest paper on autogynephilia and to talk about her own first- and second-hand experiences with autogynephilia. And it wasn't for lack of understanding the theory of autogynephilia that James wrote so favorably of it in 1998. I quote from that message at some length here, because I think it is important to see how radically James's attitude changed towards Blanchard, Lawrence, and autogynephilia from 1998 to the time in 2003 when she teamed up with Conway to devote enormous resources to discrediting Bailey, Blanchard, and Lawrence, and anyone else who spoke favorably of autogynephilia as an explanation.

In the email in question, dated November 9, 1998, James wrote to Lawrence with the subject line "Excellent paper!" to say:

I just read your autogynephilia paper ["Men trapped in men's bodies: An introduction to the concept of autogynephilia" (Lawrence, 1998)] and found it to be excellent, as expected. I'm sure you've gotten quite an array of responses, since TSs [i.e., transsexuals] are extremely reluctant to be categorized and defined by others. A definition is inherently inclusive or exclusive, and there's always going to be someone who doesn't feel they belong in or out of a definition. I got body slammed by the usual suspects in 1996 for recommending a Blanchard book. Sure, he's pretty much the Antichrist to the surgery-ondemand folks, and I've heard some horror stories about the institute he runs that justify the nickname "Jurassic Clarke." However, I found many of his observations to be quite valid, even brilliant, especially in distinguishing early- and late-transitioning TS patterns of thought and behavior. I don't buy into all of Freud, either, but that certainly doesn't invalidate his many brilliant insights.

James went on to tell Lawrence that, "Now that I have received a lot of letters from TSs, I have found that your paper backs up my own experiences." She gave some specific examples from MTFs she had known before moving on to talk about herself:

I have noticed in most TSs, and in "surgery addicts" especially, a certain sort of self-loathing, a drive to efface every shred of masculinity. While I readily admit to my own autogynephilia, I would contend that my drives towards feminization seem to have a component pushing me from the opposite direction as well [i.e., away from masculinity]. Now, if you think you've 
caught a lot of shit about autogynephilia, just imagine what would happen if I used "TS" and "self-loathing" in the same sentence! Nonetheless, I see my own transsexual feelings paralleled in the words of people with other body dysphorias. (Andrea James to Anne Lawrence, p.e.c., November 9, 1998; emphasis added)

James signed the message to Lawrence "Take care, Andrea."

How radically James's attitudes towards Blanchard, Lawrence, and autogynephilia had shifted from the time of this 1998 communication to the time in 2003 when Conway called James to her side to vigorously deny Bailey's claim that women such as them are autogynephilic. My point here is not to argue whether James, Conway, or anyone else is "autogynephilic," but rather to note that the backlash against $T M W W B Q$ became something of a purge where autogynephilia was concerned. Sharp "us versus them" division lines were drawn by Conway, James, McCloskey, and their compatriots, seemingly negating any possibility of productive dialogue about the claims made in the book with regard to possible erotic components of transsexuality.

In keeping with Conway's simplistic "good versus evil" account of the book and backlash-wherein all true transwomen are non- and anti-autogynephilic (i.e., good) and all pro-autogynephilia researchers are anti-trans (i.e., evil)Conway's master "Timeline of the unfolding events in the Bailey investigation" asserts that, as soon as Anjelica Kieltyka received and read a copy of Bailey's book, on May 3, 2003, Kieltyka "realize[d] he' [d] defamed and outed her" (Conway, 2006a). It is certainly true that, where "Cher's" identity was concerned, Bailey left a trail of clues quite easy for a close-knit, Internet-savvy community of transwomen to uncover. (I discuss this further in Part 5.) But Kieltyka's reaction to the book and to the immediate flare-up was more sanguine than Conway represents. Conway's account has Kieltyka on May 3, 2003, totally distraught over Bailey's behavior as soon as she saw the book:

Anjelica was shattered. She now realized that Prof. Bailey had intended all along to publish that old version of her story and to use her as his centerpiece "poster child for autogynephilia". He had merely been humoring her for the past 3 years with "intellectual discussions", keeping her thinking that he was open to new ideas and open to making revisions in her story.

The very next day, according to Conway,

Anjelica frantically began web searches to learn about the controversy now swirling around the book. She quickly learned that she was being defamed in the transgender community as the "poster child for autogynephilia", and that Prof. Bailey's caricature of her in the book was being used to defame other transwomen as being “autogynephiles like Cher". During her frantic searches, Anjelica came across Andrea James' and Lynn Conway's websites. She quickly realized that these sites were the key ones that were coordinating the trans community's responses to the Bailey book controversy. She immediately e-mailed Andrea and Lynn, pleading for their help in clearing her name. (Conway, 2004b)

Thus, it would appear from Conway's account as though Kieltyka immediately turned away from Bailey to look to Conway and James as her possible saviors. But Kieltyka's memory and the historical record suggest otherwise. Certainly, Kieltyka now feels Bailey "did a bait and switch" on her by telling her for years after she saw his first draft that he remained open to her counterarguments, when, in fact, he never seriously doubted Blanchard's theory or her status as an autogynephile (Kieltyka, 2006f). Kieltyka has told me, "He respected me like the colonist respects the native-he used me. There's no two ways about it" (Kieltyka, 2006d). But Kieltyka didn't contact Conway and James because she immediately hated Bailey for what she read in his book and was looking to jump to their side. Rather, she remembers:

$\mathrm{AJ}$ [Andrea James] and the rest of them wanted to lynch me, as they did Joan Linsenmeier [a colleague who helped Bailey with the manuscript] and anyone else connected with the book. They were about to hang me. I was told this by people that had frequented the Internet, and that's why they gave me the link to contact Andrea James and Lynn Conway, because I was going to be hanged by them. (Kieltyka, 2006f)

So it's true that Kieltyka was trying to save herself, but not at that point by simply rejecting Bailey and teaming up with Conway and James. In fact, in what could only be called a friendly email from Kieltyka to Bailey dated May 16, 2003nearly two weeks after Kieltyka first read the published book and contacted Conway-Kieltyka spoke warily to Bailey of the likes of Conway. In the email, headed by the joking subject line "Cher's Guide to Auto...Repair," Kieltyka wrote to Bailey:

Dear Mike, Thanks for the Cantor Review [i.e., Cantor, 2003]....I followed up on the links to your difficulties with some hysterical women [an apparent reference to Conway and James] [...] when you wrote.... "I understand that Roughgarden is slated to review my book for Nature Medicine, and I am certain that this review will be as fair and accurate as her review of my Stanford talk"....I really appreciated the sarcasm.......just wear a bike [i.e., athletic] support to your next book signing or lecture....you can borrow mine, I don't use it nor need it anymore.... Your friend, in spite of spite, Anjelica, aka Cher (Kieltyka to Bailey, p.e.c., May 16, 2003; ellipses in original unless in brackets) 
Kieltyka added a postscript saying she was enclosing "two recent pictures of me in maskon mode"-i.e., she supplied Bailey two more photos of herself crossdressed pre-transition-and she added, "see maskon.com for some missing trans links." Nearly a month later, Kieltyka wrote to Bailey's Northwestern psychology colleague Joan Linsenmeier (who was starting to get caught in the backlash) to say "We have both been caught between larger egos with agendas and motivations and axes to grind, (and swing).... And yet, I have been able to keep my head, while all about are losing theirs and blaming it on Bailey, you, and me" (Kieltyka to Linsenmeier, p.e.c., June 13, 2006; ellipses in original). This hardly sounds like a woman who, right after reading the book in early May, considered herself simply wronged by Bailey and looking to fall into the arms of fellow transwomen who would join her in roundly denouncing Bailey and autogynephilia.

Nor did the women identified as "homosexual transsexuals" in Bailey's book immediately react with disgust and dismay over the book. Indeed, regarding this, Conway's timeline-an enormous, fully hotlinked spreadsheet that makes James's "Connections to J. Michael Bailey" graphic look like a quick afterthought-leaves out entirely what I would consider one historically key event in May 2003. Shortly after the book came out, the Chronicle of Higher Education apparently decided to have its staff writer, Robin Wilson, compose a feature story on Bailey and his book (Wilson, 2003a). For the story, Wilson traveled to Evanston and Chicago, and on May 22, 2003, Bailey took Wilson out to the Circuit nightclub, along with Kieltyka and several of the women who appeared as "homosexual transsexuals" in Bailey's book, including Juanita.

No question Kieltyka comes across in Wilson's article as unhappy with Bailey's book: "Ms. Kieltyka says the professor twisted her story to suit his theory. 'I was a male with a sexualidentity disorder,' not someone who is living out a sexual fantasy, she says" (Wilson, 2003a). But the other transwomen who went out to help promote Bailey and his book appeared downright supportive, judging both by Bailey's recollection and Wilson's account (Bailey, 2006a; Wilson, 2003a). Indeed, Wilson opined "they count Mr. Bailey as their savior." She goes on:

As a psychologist, he has written letters they needed to get sex-reassignment surgery, and he has paid attention to them in ways most people don't. "Not too many people talk about this, but he's bringing it into the light," says Veronica, a 31-year-old transsexual woman from Ecuador who just got married and doesn't want her last name used. (Wilson, 2003a)

But if these women were, compared to Conway's rather selective account, relatively slow to turn against Bailey, turn four of them did. Just about two months after the gathering at the Circuit, about one month after Wilson's gossipy "Dr. Sex" feature story on Bailey, Wilson would write a sober news article for the Chronicle entitled "Transsexual 'Subjects' Complain about Professor's Research Methods" (Wilson, 2003 b). Five months later, this would be followed up by another sober dispatch, "Northwestern U. Psychologist Accused of Having Sex with Research Subject," that "subject" being Juanita (Wilson, 2003c).

So, given that Kieltyka did not immediately turn against Bailey once she saw the book (though there's no question she was frustrated and disappointed with being called autogynephilic), given that the other transwomen were helping Bailey promote the book even after its publication, given that Wilson reported they saw him as "their savior" even at that point, what happened to turn these women's warm feelings for Bailey into charges of scientific misconduct? Given the evidence, the answer is unequivocal: Lynn Conway's and Deirdre McCloskey's intervention.

According to Conway's timeline, in early June 2003, Conway began taking "field trips" (Conway 2003b) to Chicago "to meet and begin interviewing Bailey's research subjects" (Conway, 2006a). Kieltyka remembers these visits vividly, and recalls that, early in the process, McCloskey and Conway informed Kieltyka and her friends that, if they had not given informed consent to Bailey to research and write about them, it didn't matter whether Kieltyka and friends wanted to file charges against him; McCloskey and Conway would do so (Kieltyka, 2006c). As it turns out, Kieltyka, Juanita, and two other women did decide to file complaints with Northwestern University. (That didn't stop McCloskey and Conway from also doing so.) The sophisticated writing style and language of the formal charges compared to that of Kieltyka's other writings and Juanita's autobiography as it appears on Conway's site suggests that Kieltyka, Juanita, and the two other complainants had help writing their letters to Northwestern. So I asked McCloskey what her role was in preparing the formal complaints made by the four women who claimed they were Bailey's research subjects, and she replied "I helped write the letter some. I knew one of the women" (McCloskey to Dreger, p.e.c., January 22, 2007). She declined to elaborate (p.e.c., February 4, 2007).

Anjelica Kieltyka took the lead on the filings. On July 3, 2003, she submitted a letter to C. Bradley Moore, Vice President for Research of Northwestern, stating "I was a participant in a research study without being informed of that status. [...] I was unaware that I [or the women Kieltyka introduced to Bailey] were subjects of a research study, and I did not receive, nor was I asked to sign, an informed consent document" (Kieltyka to Moore, July 3, 2003; available at Kieltyka, 2003b). On July 14, 2003, a woman identified on Conway's site as "Victoria" also filed a formal complaint that "I have been a participant in a research study conducted by Dr. Bailey without my knowledge and without my approval" (available at Conway, 2003c), although her story did not appear in 
$T M W W B Q$. On July 23, Juanita filed a similar complaint (available at Conway, 2003d) and also filed a "sealed" complaint claiming that "On March 22, 1998, Northwestern University Professor J. Michael Bailey had sexual relations with me. I was one of his research subjects at that time" (available at Conway, 2003e). On July 29, McCloskey and Conway filed their own complaint, charging Bailey with "grossly violat[ing] the standards of science by conducting intimate research observations on human subjects without telling them that they were objects of study" (McCloskey \& Conway, 2003). And on July 30 came a complaint from a transwoman who felt she had been similarly "researched" by Bailey and that Bailey had ignored evidence from her history that not all transwomen fit Blanchard's scheme (available at Conway, 2003f).

Northwestern University first appointed a Provost-level inquiry committee to examine the charges against Bailey. Then, in November 2003, the university announced that the inquiry committee had found cause to continue the investigation, and so a Provost-level investigation committee was formed (C. Bradley Moore to Alice Dreger, p.e.c., August 1, 2006). Bailey bitterly remembers that the first he heard of Northwestern's decision to move to a full investigation was from a reporter for the Chicago Tribune. He adds, "Obviously Northwestern told the complainants [...] and it was on the web probably before I knew about it. [...] I think Northwestern didn't know what kind of people they were dealing with" (Bailey, 2006b).

Why did Kieltyka, Juanita, and the two other transwomen familiar with Bailey but not mentioned in the book decide to charge Bailey after years of good relations with him? Motivation is one of the most difficult things to document in historical scholarship, but I think it is fair to speculate that a number of factors may have been in play here. First, Conway, McCloskey, and perhaps also James seem to have convinced Kieltyka that she had-however unintentionally-hurt transwomen by helping Bailey "recruit" transwomen as "subjects" for his book (Kieltyka, 2006b). A letter from Kieltyka, Conway, James, and Calpernia Addams to the faculty of Bailey's department in January 2004, speaks to the degree to which they saw themselves as the protectors of other, more vulnerable transwomen:

We are socially assimilated trans women who are mentors to many young transsexuals in transition. Unable to bear children of our own, the girls we mentor become like children to us. These young women depend on us for guidance during the difficult period of transition and then on during their adventures afterwards - dating, careers, marriages, and sometimes the adoption of their own children. As a result, we have large extended families and are blessed by these relationships. Through our ex- tended families we know first-hand how Bailey's junk science is hurting young trans women. [...] You may have wondered why hundreds of successful, assimilated trans women like us, women from all across the country, are being so persistent in investigating Mr. Bailey and in uncovering and reporting his misdeeds. Now you have your answer: We are hundreds of loving moms whose children he is tormenting! (Kieltyka, Conway, James, and Addams, to the Faculty members of the Department of Psychology, Northwestern University, January 7, 2004)

I don't think there can be any doubt Kieltyka saw herself in that caring, protective role, and in charging Bailey, she must have wanted to get out of the position of being represented as the opposite - a sort of merciless pimp who turned over vulnerable transwomen to Bailey in exchange for chances to perform before his classes (Kieltyka, 2006a).

It also seems fairly clear that Kieltyka (if not the others) must have feared what might happen if she didn't cooperate with Conway and the other "investigators." After all, Kieltyka distinctly remembers initially contacting them specifically because they were "about to hang" her (Kieltyka, 2006f).

Recall too that, even before Conway's "field trips," Kieltyka had already been upset with Bailey's portrayal of her as the poster-child for autogynephilia; the fact that many other transwomen read "Cher's" story so negatively no doubt fueled Kieltyka's sense of hurt. Indeed, Bailey's continued use of Kieltyka as an example of autogynephilia-for example, at a lecture at UCLA on June 2, 2003 (see Conway, 2004b) certainly added to her growing anger. Kieltyka now seems to hold nothing but contempt for Bailey and is convinced he was intentionally duping her all along; this again suggests she came to agree with Bailey's other detractors' assessment that Bailey had made a fool of her. Kieltyka recalls Juanita feeling similarly wounded because Bailey wrote about Juanita's wedding with a snickering tone and included in the book "his opinion she got a divorce because she was too used to having sex with men and prostitution is well suited for her and the others" (Kieltyka, 2006f).

My conversations with Kieltyka also suggest that she and the other women who charged Bailey found a certain reliefperhaps even pleasure-in going from the powerless position of represented subject to the powerful position of active accuser. Through her Website, Conway in particular gave them a place to reconstruct themselves and their histories with Bailey. Thus, instead of appearing as Bailey's collaborators in their annual presentations to his Human Sexuality class, they came to call themselves his victims. Juanita's complaint of July 23, 2003 declared it "most disturbing and humiliating to find out that we were all misled by Dr. Bailey and misused [...] as part of his 'Freak Show' Demonstration of 'Homosexual' 
and 'Autogynophilic' [sic] Transsexuals" (see Conway, 2003d). (An odd claim, given that Juanita knew perfectly well that in 1999 Bailey had identified her as a "homosexual transsexual" in the newspaper article with which she fully cooperated [Gibson, 1999].)

Finally, although Kieltyka told me that the only money she received from Conway was to reimburse her for phone calls made as part of their collaboration, Kieltyka speculated to me that, in Juanita's case, monetary reward for her aid to Conway's “investigation" - including her sexual relations charge against Bailey - may have been substantially higher. Kieltyka adds "[Juanita] denied it, so I had no proof" (Kieltyka, 2006d). I asked McCloskey whether she knew if Conway financially compensated Juanita for making formal accusations against Bailey (p.e.c., January 22, 2007). McCloskey responded, "What an absurdity. Juanita is well-to-do" (p.e.c., January 22, 2007). It is certainly true that for at least several years before $T M W W B Q$ 's publication, Juanita had been wealthy; in the 2002 human sexuality textbook video, she says that "when I was a she-male [and] I prostituted myself [...] I enjoyed it [...] eas[il]y making about a hundred thousand [dollars] a year" (in Allyn \& Bacon, 2004).

Regardless of why they turned so dramatically, Kieltyka and her new allies ended up going after Bailey with virtually everything they could muster. Kieltyka used her artistic talents to provide Conway with a clever series of political cartoons on the theme of "The Sinking of "The Queen"” (see Conway, 2003g). And in July 2003, Kieltyka showed up at the meeting of the International Academy of Sex Research (IASR) in Bloomington, Indiana, where Bailey had decided to speak on the controversy over his book. Kieltyka tells me she went on "orders from" Conway "to confront Bailey" (Kieltyka, 2006a). Prohibited from entering, she remained outside to talk to anyone who would listen, handing out a flyer explaining in damning tones "How the sex research community will be hurt by J. Michael Bailey." The hand-out elaborated briefly on how Bailey was guilty of "academic dishonesty," "(still more) bad science," "unethical behavior," and "personal misconduct." The flyer called on the sex research community to

censure J. Michael Bailey for his recent acts of junk science and groundless defamation. Do not invite him to speak at your institutions. Disinvite him if he is invited. Review his manuscripts and grant proposals with great caution and skepticism. J. Michael Bailey has brought further embarrassment to a research community that is still feeling the aftershocks of John Money's John/Joan scandal.

"For more on this scandal," the reader was advised to visit "tsroadmap.com/bailey", Andrea James's Internet exposé. (Copy of flier obtained from Bailey’s personal files.)
Kieltyka's campaign seems to have caused some strain at the IASR meeting, but not to have resulted in much more than that institutionally within IASR. John Bancroft-thenDirector of The Kinsey Institute for Research in Sex, Gender, and Reproduction — did stand up to admonish Bailey after his talk, saying "Michael, I have read your book and I do not think it is science" (John Bancroft, p.e.c., July 22, 2006). When I asked him about his remark - a shot heard round the world of the controversy-Bancroft explained that "my response might have been more measured" if Bailey had "allowed adequate time for discussion by the group" (John Bancroft, p.e.c., July 23, 2006). Bancroft elaborated:

My dislike of Michael's book was that it promoted a very derogatory explanation of transgender identity which most TG people would find extremely hurtful and humiliating - hence the reaction of the TG community was not surprising. Whether based on science or not we have a responsibility to present scientific ideas, particularly in the public arena, in ways which are not blatantly hurtful. But in addition to that, Michael did not support his analysis in a scientific manner-hence my comment. (John Bancroft, p.e.c., July 23, 2006; edited February 27 , 2007)

As it turned out, someone at the IASR meeting sent Conway a detailed report of Bancroft's "not science" remark, and almost immediately her Website started prominently featuring Bancroft's denouncement of Bailey. On the page about Bancroft's remark, Conway likened it to "a similar moment back in 1954 when Joseph Welch faced Senator Joseph McCarthy and threw down the gauntlet with the statement: 'Have you no sense of decency, sir, at long last?'” (Conway, 2003h).

But if Conway thought her publication of Bancroft's remark would result in his becoming an active ally, she was mistaken. Bancroft told me "If I had known my remark would be made public, I wouldn't have said it. We like to think of the Academy meetings as opportunities for sex researchers to openly discuss their ideas and criticisms with each other, and not the outside world." Nevertheless, Bancroft maintains his concern for truly vulnerable trans people: "The Lynn Conways of the transgender world are the exception. They fight back, often in a selfdefeating fashion. In this case, they went over the top and lost credibility in the process. But the majority in that world are less resilient and more vulnerable, and they get hurt" (John Bancroft, p.e.c., July 23, 2006; edited February 27, 2007).

Several people I spoke to about the IASR meeting told me that Bancroft's remarks did not reflect anything like a consensus of the people in IASR (e.g., Pepper Schwartz to Dreger, p.e.c., February 3, 2007; Wallen, 2006). Indeed, several recalled that researcher Pepper Schwartz immediately responded to Bancroft's remark with "a small speech about civilized discourse, collegial norms, and critical analysis rather 
than name calling" (Schwartz to Dreger, p.e.c., February 3, 2007). Schwartz recalls she "said I was particularly troubled that this particular performance was more like the inquisition than a professional meeting and I wanted none of it" (Schwartz to Dreger, p.e.c., February 3, 2007).

Although she worked to get other organizations to act against Bailey, Conway also had not much success trying to use her influence with the National Academies to have Bailey's book removed from the Web, investigated, and denounced. But Conway and her allies enjoyed more success with the HBIGDA. On July 14, 2003, Conway, McCloskey, Ben Barres and Joan Roughgarden of Stanford University, and Barbara Nash of the University of Utah wrote collectively to HBIGDA about "Bailey's shockingly defamatory book." They outlined "the investigations now underway" and "urge [d HBIGDA] to begin your own investigation into Prof. Bailey's motives, methods, and activities" (available at Conway, 2003i). Walter J. Meyer, HBIGDA's President, and Bean Robinson, HBIGDA's Executive Director, responded in writing "on behalf of [HBIGDA's] Officers and Board of Directors" on October 20, 2003 to note that, while Bailey was not a member of HBIGDA (and therefore was not for them to regulate), they found "it appropriate that an investigation into these allegations is being conducted by Northwestern University." Meyer and Robinson went on to say

It is felt by many of our members that this poorly referenced book does not reflect the social and scientific literature that exists on transsexual people and could damage that essential trust. We hope that the Office for the Protection of Research Subjects at Northwestern will consider the ethical issues that are involved and we will also be sending them a copy of this letter so that they are aware of our concerns. We are also preparing a separate letter to Northwestern University to express our concerns directly. (Meyer and Robinson to Conway, McCloskey, Barres, Nash, and Roughgarden, October 20, 2003; available at Conway, 2003j)

What exactly the "separate letter to Northwestern" said, I have not been able to determine; I have asked Meyer and Robinson for a copy of the letter and have been told no one at HBIGDA can find it (Tara L. Tieso to Dreger, p.e.c., September 12, 2006). Whatever it said, through this action, HBIGDA was seen both by Bailey's allies and detractors as siding with Conway and her allies.

In utter disgust, Ray Blanchard resigned from HBIGDA on November 4, 2003. His letter stated as the reason "the appalling decision of the HBIGDA Officers and Board of Directors to attempt to intervene in Northwestern University's investigation into the allegations made by certain members of the transsexual community against Prof. J. Michael Bailey." Blanchard decried "such an intervention, undertaken without any effort by the HBIGDA to conduct their own systematic inquiry or to learn all the relevant facts of the matter," a move he felt "could only be prejudicial to Northwestern's investigation." Blanchard argued, "The HBIGDA would have been better advised to allow the Northwestern authorities, who are actually taking the trouble to investigate the allegations, to reach an impartial decision." He expressed:

deep regret that I tender my resignation[...] I have long supported the goals of the HBIGDA. I have been involved in the clinical care of transsexual persons for 24 years. During the years 1983 to 1991 , I conducted eight research studies on the therapeutic impact of hormonal and surgical treatment of transsexuals. [...] I published an additional article on the desirability of insurance coverage for sex reassignment surgery as recently as 2000. (Blanchard to Walter J. Meyer III and Bean Robinson, November 4, 2003)

As one might expect, Conway quickly announced Blanchard's resignation in victorious tones: "Blanchard resigns in a huff from HBIGDA!” (Conway, 2003k).

Meanwhile, Conway remained particularly relentless in her drive to get Northwestern to take serious action against Bailey. On May 10, 2004, a full year after the book's publication, she filed a new 49-page complaint with Northwestern. According to Conway's Website,

the new complaint contain[ed] hard evidence implicating Mr. Bailey in, among other things, (i) deliberate failures to examine counter-evidence to the theory he was studying, (ii) open defamation of those who put forward counter-evidence to that theory, (iii) the making of "remote clinical diagnoses" of mental illnesses in persons he has not ever even met, (iv) libel, (v) flagrant abuses of the power of his office and (vi) the deliberate suppression of complaints by colleagues about such conduct. (Conway, 2004c)

And Conway et al.'s formal complaints were not limited to Northwestern University. In the spring of 2004, Conway, James, and McCloskey filed a series of complaints with the Illinois Department of Professional Regulation stating that, in providing letters in support of several transwomen's SRS requests, Bailey had been practicing psychology without a license. The three also made the same complaint to Northwestern (see Conway, 2004d).

The charges of misconduct against Bailey are worth considering at length, and so I do that in the next part of this article, remaining here focused on the history of the backlash itself. But I will note here what I can of the outcomes of the formal complaints. It appears that the Illinois Department of Professional Regulation did not do anything with the complaint that Bailey was practicing clinical psychology without a license, presumably because he never took money for the SRS letters he wrote, nor did he offer or represent a therapeutic relationship 
(Clinical Psychologist Licensing Act, 225 ILCS 15/1 et. Seq.). Northwestern University appears to have quickly rejected Juanita's charge of improper sexual relations, saying it "did not merit further investigation" (see Conway, 2003e); why they likely reached this conclusion is spelled out in the next section. Northwestern concluded the remainder of its investigation in December 2004 and "The investigation committee then made its recommendations to the Provost for an appropriate response" (C. Bradley Moore to Alice Dreger, p.e.c., August 1, 2006). Much to the dismay of Kieltyka, Conway, the press, and me (among others), the university has consistently refused to say what the investigation committee found or what specific actions they recommended. Northwestern's provost Lawrence Dumas will state only " that he had 'taken action that I believe is appropriate in this situation" (quoted in Wilson, 2004). Bailey has also refused to say what the outcome of the investigation was, although he is willing to say that, if the investigation committee did its job correctly, then he was cleared (Bailey, 2005). It seems likely that if he agreed with the committee's findings, he would release the results.

When, for this history, I contacted C. Bradley Moore, Northwestern's Vice President for Research, to ask about the investigation, I received mostly the party line:

In his response to the investigative review, Provost Dumas noted that, "Northwestern has established a protocol to help ensure that Professor Bailey's research activities involving human subjects are conducted in accordance with the expectations of the University, the regulations and guidelines established by the federal government and with generally accepted research standards." As with all employees and faculty members of Northwestern University, any other internal personnel actions are confidential. (C. Bradley Moore to Alice Dreger, p.e.c., August 1, 2006; italics in original)

But interestingly, Moore did add in his response to me this telling line:

Even though the allegations of scientific misconduct made against Professor J. Michael Bailey do not fall under the federal definition of scientific misconduct, Northwestern utilized the procedures outlined in our ["]Policy on Integrity in Research and Procedures for Reviewing Alleged Misconduct["] to review the allegations. (C. Bradley Moore to Alice Dreger, p.e.c., August 1, 2006; italics added)

Thus, it would appear from Moore's statement to me that Northwestern found that Bailey did not trespass "the federal definition of scientific misconduct."

Any other clues as to how the Northwestern investigation turned out? The only notable change in Bailey's status at Northwestern is that he stepped down as department chair in
October 2004. Conway has called this a "quiet victory" (Conway, 2006a). But about this shift, Bailey and a Northwestern spokesperson have said "the change had nothing to do with the investigation" (Wilson, 2004; see also Bailey, 2006a; Bailey to Dreger, p.e.c., July 22, 2006). Indeed, the timing of it is odd; one wonders why Bailey would have stepped down as a result of the investigation in October 2004, if the investigation wasn't completed until December 2004. Meanwhile, Bailey has maintained his title of full professor, has retained tenure, and keeps teaching and conducting human subjects research; he has taken no unscheduled leaves. All of this suggests that if Northwestern found Bailey had done something wrong, it wasn't enough to change his terms of employment.

Nevertheless, throughout the various investigationsincluding Northwestern's own-the press reports generally made Bailey look quite bad as they recorded charge after charge of misconduct (see, e.g., Barlow, 2003; Becker, 2003; Wilson 2003b, 2003c, 2004). From fairly early on, at the advice of a lawyer he retained to defend himself, Bailey refused to answer reporters' inquiries, and many may have read that refusal to respond as evidence of guilt. (I recall that I certainly did, watching casually from the sidelines in 2003 and 2004.) Oddly, it seems at least from this vantage point that virtually all of the reporters working on this story from 2003 forward did not do much to independently investigate the claims being made against Bailey, even when they had the opportunity; for the most part, they merely reiterated the charges. Perhaps that is because they did not know how to go about conducting an independent inquiry without Bailey's cooperation. But even given that possibility, one particular example of strangely shallow-even critically incompletereporting stands out, namely that done by Robin Wilson for the Chronicle of Higher Education. This is significant because the Chronicle of Higher Education is an essential source of academic news; it is the newspaper of record in the eyes of many university administrators and faculty, and thus Wilson's reporting undoubtedly helped to harm Bailey's professional reputation.

Remember that on June 20, 2003, Wilson published in the Chronicle of Higher Education her "Dr. Sex" feature on Bailey and his book-a gossipy, in-person accounting that included the story of her excursion to the Circuit nightclub on May 22, 2003, with Bailey, Kieltyka, Juanita, and several of the other transwomen whose stories appeared in $T M W W B Q$ (Wilson, 2003a). According to that June 2003 feature by Wilson, Kieltyka was openly disenchanted with Bailey's account of her as an autogynephile, but by Wilson's and Bailey's accounts, the night out in May had been friendly (Bailey, 2006a; Wilson, 2003a). Even Kieltyka did not contradict this account when I asked her (Kieltyka, 2006c). The transwomen who accompanied Wilson and Bailey to the club in May 2003 understood they were helping Bailey promote the 
recently published book by meeting with Wilson—and why not, since, according to Wilson, "they count[ed] Mr. Bailey as their savior" (Wilson, 2003a).

Flash forward to July 25, 2003, a month after Wilson's "Dr. Sex" feature, just two months after the Circuit excursion. Now the Chronicle prints Wilson's sober third-person report, "Transsexual 'Subjects' Complain about Professor's Research Methods" (Wilson, 2003b). Wilson posted a similarly grave third-person dispatch on December 19, 2003, "Northwestern U. Psychologist Accused of Having Sex with Research Subject" (Wilson, 2003c). Curiously, these two news items give absolutely no hint that Wilson herself had met at least two of the women charging Bailey, i.e., Kieltyka and Juanita. There is no mention of the fact that, in late May 2003, after the book's publication, Wilson had joined Bailey, Kieltyka, Juanita, and others for that good time at Circuit, and that at the time there had been no clue that these women would ever file such serious and formal charges against Bailey. Now, it is certainly possible — as Kieltyka has told me-that it wasn't until after Conway and McCloskey talked to Kieltyka and Juanita in early June that they realized they had been "abused" by Bailey (Kieltyka, 2006c). But why, one has to wonder, didn't Wilson ask in July what was going on to have caused such a radical shift in relations? Why did Wilson not use her serendipitous insider knowledge-something any reporter would surely have been delighted to have on such a good story-to raise questions about why these women went so rapidly from being Bailey's friends to claiming a long history of abuse at his hands?

Even stranger, Wilson's (2003b) July article reported that Kieltyka "agreed to let the Chronicle print her real name," as if this were new and terribly important when, in fact, the Chronicle had printed Kieltyka's real name a full month before (Wilson, 2003a). Why was Wilson acting as if in July she and the Chronicle were completely new to this story? Genuinely baffled, I asked Wilson as much, and she repeatedly refused to go on the record with her reasoning for reporting in this way (Wilson to Dreger, p.e.c.'s, July 27, 2006 and February 7, 2007). I therefore asked her editor to explain (p.e.c.'s August 15, 2006 and September 5, 2006). After looking into the matter, the Chronicle's editor Bill Horne would only say "we stand by the accuracy, and fairness, of Robin's reporting and are not inclined to revisit decisions Robin and her editors made here with regard to what to include or exclude from those stories in 2003" (Bill Horne to Dreger, p.e.c., August 15, 2006). I simply cannot figure out what happened at the Chronicle. What I do know is that many academics (including reviewers of grant applications and manuscripts, and recipients of letters of recommendation for Bailey's students) would likely have drawn a negative opinion of Bailey from Wilson's July and December news reports.

Amazingly, somehow in the midst of all this controversy, Bailey managed to be vilified by both the right- and left-wing presses. Although the book received a warm review in the ultra-conservative National Review (Derbyshire, 2003), the equally conservative Washington Times reported both the Northwestern investigation into Bailey as well as the disgust among certain House Republicans that Bailey's sexual arousal studies received federal funding (McCain, 2003). Almost simultaneously, the ultra-liberal Southern Poverty Law Center (SPLC) claimed in their Intelligence Report that "many of those who praised" $T M W W B Q$ "belong to a private cyberdiscussion group of a neo-eugenics outfit, the Human Biodiversity Institute (HBI)" (Beirich \& Moser, 2003). When I asked Kieltyka how the SPLC got involved in all this, she explained that she had learned of the SPLC's interest in hate crimes against transgendered people, and that she had fed them information about Bailey's role in what she increasingly understood to be a vast anti-gay collusion (Kieltyka, 2006c).

Bailey indeed does belong to the HBI "private cyber-discussion group" - the sort of online discussion group usually referred to by the less thrilling name "listserv"-and Bailey acknowledges that some of the most active members of the HBI list could legitimately be called right-wing (Bailey, 2006a); this would include the list's founder, Steve Sailer. But Bailey denies being part of a well—or, for that matter, loosely - organized group that believes homosexuality is "a 'disease' that could eventually be eradicated" (Beirich \& Moser, 2003). When in our interviews I mentioned the SPLC article to Bailey, his tendency was to look either bewildered or amused, even after I explained to him that Kieltyka saw the 2001 article he published with lawyer Aaron Greenberg, "Parental Selection of Children's Sexual Orientation," as clear evidence of his push for an anti-gay eugenics.

In that article, Bailey and Greenberg argued that "even assuming, as we do, that homosexuality is entirely acceptable morally, allowing parents, by means morally unproblematic in themselves, to select for heterosexuality would be morally acceptable." They believe "this is because allowing parents to select their children's sexual orientation would further parents' freedom to raise the sort of children they wish to raise and because selection for heterosexuality may benefit parents and children and is unlikely to cause significant harm" (Greenberg \& Bailey, 2001, p. 423). Bailey told me this article doesn't make him anti-gay or eugenical. He is not trying to "improve" the human stock through the elimination of theoretical "gay genes" and, as for the question of the article's attitude towards gay people, the paper clearly states:

$[\mathrm{H}]$ omosexuality, like heterosexuality, is ethically neutral. Because homosexuality causes no direct harm to others (other than those who take offense at it on irrational and/or inhumane grounds) and because homosexual behavior is crucial to the ability of homosexual people to enjoy their lives (as heterosexual behavior is to heterosexuals), homosexuality should not be morally condemned or proscribed. (Greenberg \& Bailey, 2001, p. 424) 
Bailey has insisted that, in this paper, he and Greenberg simply argued one thing: that parental rights could reasonably be understood to include genetic selection against-or for-a theoretic "gay gene" in the same way that parental rights are reasonably understood to include the right to raise children in parents' religions. A close reading of the paper certainly seems to bear out Bailey's claims about it.

Although it is clear Kieltyka believes the "collusion and possible conspiracy" is absolutely key to understanding the backlash against Bailey's book and Conway's role in it, it is difficult for me to sum up what Kieltyka sees as the evidence for a vast network of cooperation among supposedly anti-gay researchers, pundits, engineers, and politicians. I have found her theory confusing enough that at least three times I offered to put Kieltyka's own account of it up on my personal Website, so that she would feel her theory has been accurately represented (Dreger to Kieltyka, p.e.c.'s September 3, 2006 and September 22, 2006; Dreger to Kieltyka, letter, September 6, 2006). She has not taken me up on the offer. I do know she is sure the scheme reflects the "God, guns, and (anti) gay" agenda of right-wing Republicans, and that it intimately involves members of and testifiers to the President's Council on Bioethics, as well as members of and contractors to NASA and the Defense Department (Kieltyka, 2006a, 2006c, 2006d; p.e.c. from Kieltyka to approximately 150 people, subject line "What's Wrong With This Picture-Scowcroft-ZederConway???", September 2, 2005). I believe I should also report-since Kieltyka mentioned it repeatedly-that her conviction that she had accidentally stumbled onto something really big was bolstered when she appeared on the KKKrelated "New Nation News" Internet "shit list" (Kieltyka, 2006a, 2006d), and, most frighteningly, when she woke up one day to find a dead cat laid out on her doorstep, a cat who looked very much like her own dear pet (Kieltyka, 2006a, $2006 \mathrm{~b}, 2006 \mathrm{~d}$ ). (She alerted the local police to a possible hate crime [Kieltyka, 2006a].) I should also note that, although Kieltyka insisted to me that Bailey is just the "fall guy" in the much higher-stake scheme she hoped I would point my attentions to - a scheme where Conway ranks significantly higher up than Bailey (Kieltyka, 2006a)_-she is still really angry with Bailey for having used her story as an example of autogynephilia.

As mentioned earlier, Conway seems to have remained cool to Kieltyka's wide-ranging findings that pointed to Bailey as being a collaborator in a massive anti-gay agenda shared by right-wing Republicans. But apparently James did not, because her 2003 graphic of "J. Michael Bailey connections" suggests that, at least in October 2003, James bought into Kieltyka's grand unifying theory-or at least that she thought it a useful new form of rhetoric to use against Bailey (James, n.d.-a). But, in general, James took a more direct - though not less expansive - approach than Kieltyka. Thus, in an effort to undermine $T M W W B Q$, James tried to discount, denigrate, or discredit anyone who was seen as supportive of the book. So her Website includes an appraisal of Simon LeVay-who works on the biological origins of sexual orientation and who blurbed Bailey's book-calling him "a dilettante" and explicitly likening him to "the race scientists who influenced Nazism by emphasizing biological differences of ethnic minorities" (James, n.d.-b). James seems to have been unable to find anything usefully objectionable about co-blurber Steven Pinker; her page on him consists mostly of a cartoon of "Pinker and the Brain plotting their takeover of the intellectual world" and scattered "notes to address later" (James, n.d.-c).

James also sought to force anyone who might be on the fence to side with her or face the consequences. For example, in April 2003, when she discovered endorsements of TMWWBQ on Anne Lawrence's Website, James sent Lawrence an email telling Lawrence, "Ido not deny your legitimacy as a woman or ascribe motivations to you in order to make my own behavior and desires seem more acceptable, yet if you and Bailey feel entitled to do so to me, I will be forced to travel this low road as well and respond in kind." She ended with a menacing tone: "I believe you find yourself at another crossroads as a community leader. You have a choice to make. [...] I strongly suggest you stake out the places where your opinion differs from Bailey's, or you will find you have squandered even more of the goodwill and respect you used to have in abundance" (p.e.c., April 15, 2003). Once it became clear Lawrence was going to stick with the theory she found most correct, James mounted an extensive attack on Lawrence's professional reputation, publicizing an incident where Lawrence was charged with professional misconduct. The fact that Lawrence was ultimately fully cleared appears nowhere on James's "exposé" of the events (Lawrence, 2006a). Had Lawrence supported the feminine essence narrative over Blanchard's taxonomy, one could easily imagine Conway, James, and the like circling wagons to protect their fellow transwoman. Lawrence's supposed sin of professional misconduct is clearly not the issue; her allegiance to Blanchard's theory is. (By contrast, nowhere on James's extensive site in her favorable use of the work of pro-feminine-essence therapist Mildred Brown does James mention that "Brown paid off a former client to drop a $\$ 2.5$ million lawsuit that alleged a personally damaging and ruinous sexual affair" [Rendon, 1999].)

James and her allies reacted powerfully when a new site claiming to represent self-identified homosexual transsexuals sprang up. The "Transkids.us" site was organized by intersex activist Kiira Triea, whom I knew coincidentally through my intersex advocacy work in 1998-1999 and with whom I reconnected after my blog on James. When we reconnected, Triea told me that, following the publication of TMWWBQ and the enormous backlash against it, she set up the Transkids site as a way for transwomen she was helping out in Baltimore to 
voice their stories and analyses - stories and analyses that largely supported Blanchard's taxonomy and thus Bailey's book. Triea and her friends prefer the term "transkids" to "homosexual transsexuals" "because their problems started so young" (Triea, 2006). In fact, Triea bonded with the transkids because she could relate to that aspect of their histories; Triea was born intersex and raised male, and at 14 wound up in the famous gender identity clinic led by John Money at Johns Hopkins University. Diagnosed by Money's team as (in Triea's words) a "failed male," she was put through a sex reassignment Triea experienced as brutalizing (Triea, 1999).

Although Triea and the transkids knew the extent of the anger against Bailey, they never imagined that so much of it would be directed toward them for daring to defend Blanchard and Bailey. She recalls:

We had been working on the transkids.us site for several months and when it was done we announced it in various places. The very next morning, one of the transkids called on the phone in a panic, really scared, because overnight news of our website had caused such outrage on the Internet. Andrea James was saying "if you have any information about any of these people give it to me." I looked at two of the forums, the worst ones, and the outpouring of hatred and violence was just unbelievable. It was frightening because I had never seen anything like that. They were saying things like we needed to be "infiltrated and taken out" or "vectored and destroyed," all this military stuff! (Triea, 2006)

Triea told me, "We talked about taking the website down, because we didn't want anyone to get hurt" (Triea, 2006). But in the end, they left it up and continued to post new material occasionally. The fact that the transkids have occasionally criticized some of Bailey's book (see, e.g., Velasquez, 2004) did not seem to mollify James. James' site still calls for readers to send in any "email, attachment or photo from" the transkids.us writers "for analysis by our investigators. We need to vector and expose this kind of online fakery before someone takes them seriously" (James, n.d.-d).

For her part, Deirdre McCloskey, too, led sections of the counterattack. We see this most clearly in the case of the LLF's collision with the Bailey controversy. On February 2, 2004, the LLF announced the finalists for the Lambda Literary Awards, and included among the five books in the "Transgender/ GenderQueer" category was TMWWBQ. Conway's site on "the Bailey Investigation" tends to assume that all positive publicity for the book was the production of the publishers' or Bailey's agents, and the LLF case is no different. According to Conway's master “Timeline," Bailey's publicists managed to get the book nominated for a Lambda award (Conway, 2006a).

But Jim Marks, then Executive Director of the LLF, corrected the record when I spoke with him. "The book was not originally nominated by the publisher," according to Marks. "It was added to the list by a member of the finalist committee and after the finalist committee had selected it, we went back to the publisher, who paid the nominating fee" (Jim Marks, p.e.c., July 22, 2006). Bailey remembers with annoyance that his publisher let him know about it only to tell him they assumed he didn't want the book nominated. Presumably, by then, the publisher was weary of being attacked over the book. Bailey recalls, "My editor was always supportive, although I didn't deal with him much after [the book] came out. The publicist was also very positive. But the people higher up definitely seemed torn between supporting me and appeasing the people who were giving them trouble" (Bailey, 2006b). Bailey responded that of course he wanted the book nominated, so the fee was paid, and the nomination became official.

Immediately after the nominations were announced, Deirdre McCloskey contacted Jim Marks to let him know she was outraged. Marks remembers, "I first realized that we had a problem on our hands when I got a vehement phone call from Deirdre McCloskey, Professor of Economics and English at the University of Illinois at Chicago. McCloskey insisted that we immediately remove the book from the list of finalists" (Jim Marks, p.e.c., July 22, 2006). In an email sent on the day after the announcement, McCloskey told Marks the nomination "would be like nominating Mein Kampf for a literary prize in Jewish studies. I think some apologies and explanations and embarrassment are in order" (McCloskey to Marks, p.e.c., February 3, 2004; available at Conway, 2005a). Marks wasn't sure exactly what to make of this at first:

While I was a little taken aback by the campaign of a university professor to relegate a book to a kind of Orwellian non-history, we might have considered taking administrative action and removing the book from the list if McCloskey's view had been universally that of the transgender community. The LLF was in some senses an advocacy organization. Its stated mission was to advance LGBT rights through furthering LGBT literature. We would clearly have grounds for removing a book that was in fact hostile to the Foundation's mission. (Jim Marks, p.e.c., July 22, 2006)

But Marks soon learned that "McCloskey's point of view, although widely shared, was not universally that of the transgender community. Among the torrent of e-mails we received, a minority came from transgender people who supported the book and urged us to keep it on the list" (Jim Marks, p.e.c., July 22, 2006). Marks recalled to me,

I had no expertise in this area (which is one reason we were blind-sided by the controversy). My main concern was maintaining the integrity of the nominating process; I didn't feel like I could ask a finalist committee to take 
the time and effort to select finalists and then simply overturn their decision without legitimate grounds. I informed the finalist committee of the controversy and asked them what to do. They re-voted and said, keep the book on the list. We did and sent the book out to the transgender panel of judges. (Jim Marks, p.e.c., July 22, 2006)

Following this decision to keep the book in the running, the pressure McCloskey, Conway, and others brought to bear on the LLF to remove Bailey's book from the running became intense. A worldwide online petition was started by Christine Burns, a leading trans advocate in the U.K., insisting "that the book [...] be withdrawn forthwith from the list of nominees at our collective request." It quickly reached nearly 1,500 signatures (see http://www.petitiononline.com/mod_perl/signed. cgi?bailey).

In the style of the rest of her "investigation," in the LLFnomination affair, Conway also encouraged her followers to take to task anyone who could be seen as helping Bailey. Thus, she listed on her site "Members of the Lambda Literary Foundation committee who selected Bailey's book," with this heading:

We thought you'd like to know who the gay men and lesbian feminists are who launched this attack on us. Following are the names, addresses, URL's and phone numbers of these people. We think that they should hear from you, so as to gain some comprehension of the scale of the pain they have inflicted on transwomen throughout the world. [...] Note: There is some evidence that the owners and employees of several of the book stores listed below have specific lesbian-feminist policies of welcoming only "womyn born womyn" (thus excluding transwomen) as customers in their stores. We suggest that our investigators out there quietly gather evidence about any discriminatory policies employed by stores listed below, for future publication on this site. (Conway, 2005a)

In a little over a month after McCloskey's first call to Marks, the pressure did result in what McCloskey, Conway, and their allies sought. By early March, according to Marks, a judge within the LLF "raised concerns, we went back to the finalists committee one more time, a member changed their vote and we withdrew the book from consideration" (Jim Marks, p.e.c., July 22, 2006). Only one vote had flipped, but it was enough to have the book removed.

In their public comments, those on the Finalist Committee disagreed about whether this action was tantamount to censorship. Kris Kleindienst is quoted in an LLF announcement as saying, "Removing the book from the list is not censorship. The book is widely available, has been widely reviewed and is not about to be denied to the public. What we are doing is behaving in a responsible manner to make sure the list of finalists is compatible with the Foundation's mission." But Victoria Brownworth, along with other members of the committee, disagreed, saying "if we take the book off the list we are indeed censoring it. It doesn't matter what our reasons are" (Jim Marks to “distribution list,” p.e.c., March 12, 2004, reproduced at Conway, 2005a).

Jim Marks's challenging experience with the controversy and his new critics did not end there. As was typical in the whole $T M W W B Q$-related affair, Conway's and James's site continued to track their perceived-enemy's actions. In 2005, in a link highlighted on Conway's site, James victoriously announced on her Transsexual Road Map site that Marks had been "ousted as Executive Director" of the LLF, claiming that the cause was "the mishandling of the Bailey matter, combined with late publication deliveries and financial woes" (James, n.d.-e). Marks says this is simply not true: "I did not resign [...] because of financial difficulties. The 12 month period from June 2004-May 2005 was the most successful year, financially and organizationally, that the Foundation had ever had." Instead what happened was that the LLF board decided to reorganize the Foundation in a way that Marks "did not think [...] was a viable business model and [he] resigned rather than try to implement it". He adds, "As far as I know, the controversy over $[T M W W B Q]$ played no part in the decision of the board to reorganize the Foundation. When I resigned, it was over 15 months in the past and of no immediate relevance to the Foundation" (Jim Marks, p.e.c., July 22, 2006). James's and Conway's sites continue to say otherwise.

All of this was no doubt taking its toll, most especially on Michael Bailey. And I don't think there can be any doubt that, via their work with the press, their orchestrating of charges of scientific misconduct against him, and their encouraging of vocal objections at any public talks Bailey might give, Conway and James in particular were trying to make Bailey as miserable as they could. In my interviews with him, Bailey resisted admitting to misery, but conversations with his family and friends suggest the multi-year assault on so many fronts did wear on him. Because they believed he had rhetorically assaulted them, his enemies would seem to deny him any safe haven, however personal. At one point, Conway even decided to contact Bailey's close personal friend and departmental colleague, Joan Linsenmeier, to suggest that Linsenmeier tell Bailey he needed to be concerned for his personal safety. Linsenmeier told me about Conway's call:

I don't recall exactly what she said, but basically it was that some people with very negative feelings toward Mike knew where he lived, that this put him in danger, and that she thought I might encourage him to consider moving. [...] while she definitely scared me, this was 
something I chose not to share with Mike at the time. (Joan Linsenmeier, p.e.c., August 17, 2006)

This sort of direct appeal to Bailey's colleagues would continue unabated for years. In September 2003, while Bailey was Chair of the Department of Psychology at Northwestern, James wrote to all of Bailey's departmental colleagues, feigning concern for him:

Northwestern's Psychology Department tacitly allows someone suffering from what the DSM calls alcohol abuse and dependence to run the department. As psychologists and friends, you must know that if Bailey continues his downward spiral, it's largely because you and your colleagues didn't step in. [... I'm sure some of you will continue to respond with self-righteous indignation or with fear of me and my message. For the rest of you, I hope this little rock tossed through your window makes a real human connection. (Andrea James to the faculty of the Northwestern University Psychology Department, p.e.c., September 15, 2003)

Similarly, in January 2004, members of Bailey's department all received the previously mentioned letter from Kieltyka, Conway, James, and Calpernia Addams. The ostensible cause of the letter was to alert them to the SPLC report:

With this letter we wish to inform you that the Intelligence Report identifies J. Michael Bailey, the Chairman of the Department of Psychology at Northwestern, as a central figure in an elite reactionary group of academics, pundits and journalists now especially active in an insidiously noxious "scientific" and "scholarly" pursuit of institutionalized bigotry and defamation of transsexual women[....] We urge you to suspend disbelief. Read those SPLC Intelligence Report articles for yourselves. Then contemplate the role that some psychologists, including your Department Chairman, are playing in fostering hate and violence against young transsexual women. (Letter from Anjelica Kieltyka, Lynn Conway, Andrea James, Calpernia Addams to faculty members of the Department of Psychology, Northwestern University, January 7, 2004)

As late as 2005, Conway was still using this approach, choosing to write to Alice Eagly, who had replaced Bailey as chair of the department. Conway insisted that, because of Bailey, "the deep stain on Northwestern Psychology remains." But she offered a solution:

the internal culture of the Department could perhaps be improved over time if signals were quietly sent that it now at least tolerates open discussion of alternatives to Mr. Bailey's views [...] It might also be important to reflect upon what is being taught about transsexualism to Northwestern's undergraduates in the large "sex courses" given by your Department's faculty members. (Letter from Lynn Conway to Alice Eagly, January 26, 2005)

Unlike Conway, James considered even Bailey's family and non-professional friends fair game in her own branch of the "investigation." So, in 2005, James obtained pictures of Bailey's girlfriend from 2003 and mounted a special page mocking her. It included a visual feature that morphed Bailey's girlfriend's face into Bailey's face from his high school yearbook picture-presumably implying Bailey is autogynephilic, though the exact meaning is unclear. Bailey's nowex-girlfriend has asked James to take down the page to no avail; it is still the first page you get when you Internet-search that woman's name (Bailey to Dreger, personal communication, September 19, 2006).

In May 2003, James created a special portion of her site to go after Bailey's children. In her own words, this special page was "a very coarse and mean-spirited screed, designed to reflect what I consider [Bailey's] own motivations to be. [...] A taste of his own medicine." For this project, James took from Bailey's homepage photos of his son Drew and daughter Kate when they were in junior high and primary school, respectively. She then superimposed black bands over their eyes, presumably to mimic the dehumanizing pictures of trans people in the medical literature. Under the picture of Drew, using mostly a line from Bailey's book about transwomen, she added the caption, “There are also kids like 'Drew' who work as waiters, hairdressers, receptionists, strippers, and prostitutes, as well as in many other occupations." Meanwhile James labeled Kate's picture this way: “'Kate': a cock-starved exhibitionist, or a paraphiliac who just gets off on the idea of it? We'll find out in 12 easy questions!" In an update on this page, James delighted "that professionals are reading this page and acting with disgust." Indeed, the negative reactions she was getting made her decide to ratchet up her satirical analogizing of Bailey's book to his children. She now imagined "a classification system to categorize Bailey's children. There are two types of children in the Bailey household: Type 1, who have been sodomized by their father, or Type 2, who have not" (James, 2003a).

James did eventually take enough flak over her mockery of Bailey's children that she withdrew the special page about them. She claims on her site that she issued via Drew Bailey a sincere apology to him, his sister, and his mother (James, n.d.f), but Drew Bailey says she did nothing of the sort, even after he contacted her to defend himself and his sister: "there was nothing in her response that could have been reasonably interpreted as a sincere apology" (Drew Bailey, 2006). In our conversation, Drew, now 22 years old, added, "Something [else] that really bothered me involved her characterization of our family dynamic. She said that my father had abandoned us, 
that we were his 'ex family.' That really hurt because it is completely untrue" (Drew Bailey, 2006). I asked Michael Bailey if it is possible that Andrea James was referring to the terms of his divorce in speaking of his alleged "abandonment." Bailey replied that the divorce had been friendly. When I asked if he had any evidence of that, he thought a moment, and remembered that he and his then-wife Deb had used the same divorce lawyer (Bailey, 2006a).

As it turns out, the Bailey clan remains quite close-knit in spite of the parents being divorced. Thus, James' characterization of Bailey "abandoning" his family could only be called a misrepresentation at best. The Baileys are inclined to call it a vicious lie. By all accounts, the Baileys celebrate holidays together, are in constant close contact, and even vacation together. When I interviewed Deb Bailey in Evanston the day after she returned from a Maine vacation with her partner, her children, her ex-husband, and other close friends, she told me "It's eleven years since we've been divorced and he still rides his bike [over], stops by, all the time to see the kids [...] and to see me." She confirmed for me that she and her exhusband had shared the same divorce lawyer, and indeed remembered somewhat sentimentally how they enjoyed each other's company the day of the court divorce proceedings. She also remembered that, in 2003, when the stress of the book backlash was getting particularly intense, Michael Bailey came to her house to talk for hours about it with her. Deb summed it up this way: "Mike and I have an unusual relationship in that we care for each other a lot. Married was not a good thing, but friends is a fabulous thing, and I have only the utmost respect for him" (Deb Bailey, 2006).

While Bailey's family and friends privately rallied around him, throughout the controversy over $T M W W B Q$, Bailey's colleagues did not do much to visibly side with one party or the other. This may have been because-as John Bancroft suggested above, and Anne Lawrence seconds below-it became difficult, if not impossible, to put forth any kind of judicious critique of the book given the highly charged terms of the debate. One sexologist who did seem to take the side of Conway is Eli Coleman of the University of Minnesota. In response to the outrage coming from Conway and her allies, Coleman expressed his concerns about Bailey's book and promised in an email he copied to Conway, "we will do all we can do to respond to this situation" (available at Conway, 2003i). Then, at the 2003 Ghent meeting of HBIGDA, Coleman criticized Bailey's book as an "unfortunate setback." At his 2005 lecture to the International Foundation for Gender Education, Coleman again "said pretty much what I said in Gent - that it was an unfortunate setback in feelings of trust between the transgender community and sex researchers." $\mathrm{He}$ also specifically "said thanks to Lynn Conway that the concerns of the transgender community had been brought forth and articulated" (Coleman to Dreger, p.e.c., August 4, 2006). According to Conway, it is "courtesy of Dr. Coleman" that her site shows a slide from Coleman's IFGE lecture-namely a reproduction of $T M W W B Q$ 's cover with the words "Unfortunate Setbacks" added above it (Conway, 2005b). When I asked him if he gave Conway the image, Coleman told me "I have no idea where she got the slide" (Coleman to Dreger, p.e.c., February 6, 2007).

A number of Bailey's colleagues who might have been inclined to explicitly defend him suggested to me in conversation that they feared being both ineffectual and attacked; certainly his colleague Joan Linsenmeier found herself set upon by both Conway and James as a consequence of her public positive association with Bailey (see, e.g., James, 2003c). One sexologist suggested to me that some colleagues who might have otherwise defended Bailey publicly might have stayed out of the conversation because, in 2003 and 2004, as charge after charge of scientific misconduct piled up, colleagues might have believed "where there's smoke, there's fire." But things have clearly shifted since then; Bailey is now quicker to call on colleagues to help, and they are quicker to respond. When the queer-community-oriented Chicago Free Press ran an antiBailey editorial in August, 2006 in response to a new tip from Kieltyka ("Bad Science," 2006), Bailey asked his colleagues to write letters to the editor, and at least 18 immediately did (Bailey to Dreger, p.e.c., January 23, 2007).

Meanwhile, although strife within the trans (especially the transwomen) activist and support circles certainly predated the publication of $T M W W B Q$, the controversy over the book seems to have substantially exacerbated it. A number of the transwomen who wrote to me after my original blog on Andrea James volunteered that they had been harassed, intimidated, and sometimes electronically erased for speaking autobiographically of autogynephilia or positively of Blanchard, Bailey, or Lawrence. (All of these correspondents asked to remain anonymous for fear of further attack.) The heat around Bailey's book appears to have entrenched for many people the "if you're not with us, you're against us, and you'll be treated as such" mentality. Even transman/trans-advocate Jamison Green, who has publicly criticized $T M W W B Q$ and Bailey (Green, 2003), has said,

I have been disappointed by some of the vitriolic attacks that Bailey received from trans people at the height of the controversy. I strongly feel that scholarly (and creative) work should be reviewed on its merits and that resorting to personal attacks on creators of published work is uncalled for at best and demeaning to the critic at worst. Such tactics actually undermine productive critical dialog[.] (Jamison Green, p.e.c., August 20, 2006)

And indeed the divisive shockwaves from the controversy over $T M W W B Q$ are still reverberating within trans circles in ways that don't seem productive or civil much of the time. Whether that will change remains to be seen, and will probably depend much on whether leaders and followers within 
trans advocacy and activism can find a way to move forward while the "if you're not fully with us, you're against us" mentality remains. For his part, Green told me "I sincerely hope that one day intelligent people will be able to consistently exhibit civil behavior toward each other in all aspects of social interaction" (Jamison Green, p.e.c., August 20, 2006).

\section{Part 5: The Merit of the Charges Made Against Bailey}

I think it is fair to say, given the historical evidence noted above, that the firestorm against The Man Who Would Be Queen was initially motivated by a few powerful transsexual women's strong public rejection of Blanchard's theory of MTF transsexualism. But as we have also seen above, that firestorm quickly came to be fueled by allegations that $\mathrm{J}$. Michael Bailey had behaved in all sorts of unethical, illegal, and immoral ways in the production of his book. This move on the part of Bailey's detractors - from questioning the message to questioning the messenger-effectively directed public attention away from the book itself and Blanchard's theory towards $T M W W B Q$ 's author. What then of the merit of the charges that Bailey behaved unethically, illegally, and even immorally in producing $T M W W B Q$ ?

In providing this history, it would be convenient to be able to simply report the merit of the charges made against Bailey as determined by some reliable investigatory body. But I am unable to do so. Besides the rather odd and brief inquiry made by the SPLC and those "investigations" of Bailey made by Conway, James, and their cohort- "investigations" which, as noted above and below, appear factually and ethically flawed in key respects - apparently the only formal, institutional investigation made of Bailey was that conducted by the Provost's office of Northwestern University. No other groupincluding the National Academies, various professional organizations like HBIGDA and IASR, and the Illinois Department of Professional Regulation-seems to have found reason to proceed with any deep inquiry into Bailey's work, in spite of many calls to do so from Conway, James, Kieltyka, McCloskey, and others. And, as noted in the last section, neither Northwestern nor Bailey has publicly revealed the results of the university's lengthy investigation, except insofar as: (1) Northwestern's Vice President for Research has said that "the allegations of scientific misconduct made against Professor J. Michael Bailey do not fall under the federal definition of scientific misconduct"; and (2) Northwestern's Provost has said that the university "has established a protocol to help ensure that Professor Bailey's research activities involving human subjects are conducted in accordance with the expectations of the University, the regulations and guidelines established by the federal government and with generally accepted research standards" (C. Bradley Moore to Alice Dreger, p.e.c., August 1, 2006). It seems that if Bailey were completely happy with the outcome of the investigation, he would release the results, but the apparent lack of change in Bailey's university status following the December 2004 conclusion of the investigation suggests the university found nothing too damning. Still, I think it unscholarly to rely on such ambiguous evidence to deduce anything meaningful about Bailey's conduct. Consequently, I consider here the allegations of misconduct made against Bailey with regard to the production of his book, and examine what the sources tell us about the merit of those charges.

Of the myriad charges organized and broadcast against Bailey by Conway, James, and McCloskey, arguably the two most serious have been (1) that Bailey conducted human subjects research that required Northwestern University's IRB approval and oversight without seeking or obtaining that approval and oversight, and (2) that he had sex with the woman called Juanita in the book at a time when she was his research subject. These two charges turn out to be interrelated, so I'll deal with them first, one right after the other.

Did Bailey conduct IRB-qualified human subjects research without IRB oversight? According to reproductions posted on Lynn Conway's "Bailey investigation” Website, in their 2003 complaints about Bailey made to Northwestern, Anjelica Kieltyka, Juanita, and two other transsexual women whose stories did not appear in $T M W W B Q$ all claimed that they were "participant[s] in a research study without being informed of that status" (Kieltyka to C. Bradley Moore, July 3, 2003, available at Kieltyka, 2003b; see also Conway, 2003c, 2003d, 2003f). Kieltyka's complaint of July 3, 2003, went further, stating that she expected Bailey to be "found [...] in violation of University and federal policies" because, she implied, he had been conducting IRB-qualified human subjects research on her and her friends without IRB approval and oversight (Kieltyka to C. Bradley Moore, July 3, 2003, available at Kieltyka, 2003b). Indeed, by his own admission, Bailey did not seek or obtain approval from Northwestern's IRB to talk with Kieltyka, Juanita, and other transsexual women about their lives for purposes of his writing about them (Bailey, 2005). But did Bailey need IRB approval and oversight in this case?

Answering this question requires both general consideration of the IRB regulations and specific consideration of Bailey's relations with the people whose stories he recounted in his book. First the general: In the U.S., universities that receive federal funding are required to maintain oversight boards to ensure that qualified human subjects research is conducted in an ethical manner. To quote from Northwestern's Office for the Protection of Research Subjects:

The Institutional Review Board (IRB) is designated by Northwestern University (NU) to review, to approve the initiation of, and to conduct periodic review of research involving human subjects or materials obtained from 
human subjects. Federal law and/or NU policy mandates prior written and dated IRB approval of such research regardless of the funding source. (Office for the Protection of Research Subjects, n.d.)

\section{As Robin Wilson of the Chronicle of Higher Education noted} in her July 25, 2003 news report of the first two charges made against Bailey, "According to federal regulations, a human subject is someone from whom a researcher obtains data through 'interaction,' which includes 'communication or interpersonal contact between investigator and subject'" (Wilson, 2003b).

There's no question Bailey obtained information about their lives from observing and talking with Kieltyka, Juanita, and the other transsexual women who did and did not appear in $T M W W B Q$. In that sense, they would seem to count as "human subjects," presuming the information he gathered from them could be called "data."

But, as Wilson and many other writers on the Bailey controversy have failed to note, the kind of research that is subject to IRB oversight is significantly more limited than the regulatory definition of "human subject" implies. What is critical to understand here is that, in the federal regulations regarding human subjects research, research is defined very specifically as "a systematic investigation, including research development, testing and evaluation, designed to develop or contribute to generalizable knowledge" (United States Department of Health and Human Services, 2005, Sect. 46.102, def. "b”). In other words, only research that is truly scientific in nature- that which is systematic and generalizable - is meant to be overseen by IRBs. Thus, a person might fit the U.S. federal definition of "human subject" in being a person from whom a researcher gains knowledge through interpersonal interaction, but if the way that the researcher gains the knowledge is not systematic and the knowledge she or he intends to gain is unlikely to be generalizable in the scientific sense, the research does not fall under the purview of the researcher's IRB.

It is worth noting here, for purposes of illustration of what does and doesn't count as IRB-qualified work, that I consulted with the Northwestern IRB to confirm that the interviews I have conducted for this particular project do not fall under the purview of Northwestern's IRB. Although I have intentionally obtained data through interpersonal interaction, the interview work I have conducted for this historical project has been neither scientifically systematic nor generalizable. That is, I have not asked each subject a list of standardized questionsindeed, I typically enjoyed highly interactive conversations during interviews; I have not interviewed all of my subjects in the same way; I have negotiated with some of them to what extent I would protect their identities. This is a scholarly study, but not a systematic one in the scientific sense. Nor will the knowledge produced from this scholarly history be generalizable in the scientific sense. No one will be able to use this work to reasonably make any broad claims about transsexual women, sex researchers, or any other group.

When I put my methodology to the Northwestern IRB, the IRB agreed with me that my work on this project is not IRBqualified (Eileen Yates to Dreger, p.e.c., July 31, 2006), i.e., that, although I have obtained data from living persons via interactions with them, what I am doing here is neither systematic nor generalizable in the scientific sense. Had the IRB disagreed with me on this point-which, knowing the regulations, they did not-I would have pointed them specifically to the 2003 clarification by the U.S. Office for Human Research Protection (OHRP) that "oral history interviewing projects in general do not involve the type of research defined by [Department of Health and Human Services] regulations and are therefore excluded from IRB oversight" (Ritchie \& Shopes, 2003). The Oral History Association sought this clarification in response to what many scholars have come to call "mission creep" on the part of IRBs, i.e., the move on the part of many IRBs to claim regulatory rights to work that was never intended by the federal government to count as human subjects research (Center for Advanced Study, 2005; see also American Association of University Professors, 2006). The Oral History Association and the American Historical Association have gotten fed up enough with IRB mission creep that they recommend historians like me not even consult with their IRBs when planning to take oral histories; they advise scholars instead to simply inform their Chairs and Deans of the 2003 clarification (Ritchie \& Shopes, 2003). I went against their recommendation in this case and actively sought confirmation of exception from my own IRB partly out of project-relevant curiosity as to how the Northwestern IRB views these kinds of interviews, and partly out of fear of being charged with IRB violation in retaliation for producing this history.

In terms of how this all applies to the claim that Bailey was violating IRB regulations, one could argue that the 2003 clarification of the OHRP about oral histories came after he wrote $T M W W B Q$ - that the clarification postdates his work. That is true, but the clarification about taking and relaying individual stories was not a new ruling. It was simply a clarification that oral histories were never meant to be overseen by IRBs. Moreover, I'm not sure we can even reasonably use the term "oral histories" to describe what Bailey did with Kieltyka, Juanita, and the other people whose stories were relayed in the book-that is, I'm not sure it counted as any kind of serious scholarship (which real oral-history taking is). The information about individuals that Bailey gathered for the book from Kieltyka, Juanita, Braverman, and others he obtained haphazardly — without any developed plan of research — from their occasional presentations to his classes, from their joint social outings, and from one-on-one discussions that occurred on an irregular basis. Bailey did conduct a few fill-in-the-blank 
discussions with Kieltyka, Juanita, and others (Bailey to Dreger, p.e.c., August 22, 2006)—discussions during which, as I show below, they knew he was writing about them in his book, and with which they cooperated. But these fill-in-the-blank discussions can again hardly be called systematic or productive of generalizable knowledge. When I pressed him to consult or perhaps even turn over to me the notes he took from these conversations, Bailey admitted he had no organized notes that he had bothered to keep. Obviously, he never really thought of these discussions as research-systematic work meant to be productive of generalizable knowledge-any more than he ever imagined that the women who seemed eager to tell their stories and have him write about them might later charge him with abuse. Otherwise, he surely would have protected himself and his work by being significantly more organized. By comparison, for the systematic and generalizable psychological and sociological studies of transsexual women and others to which he occasionally refers in the book (e.g., Barlow, 1996), Bailey and his lab did seek and obtain IRB approval from Northwestern.

Historically speaking, the confusion over whether Bailey violated human subjects research regulations is somewhat understandable, both because many people are unfamiliar with the regulations and because of $T M W W B Q$ 's style. In the book, the way in which Bailey refers offhandedly and irregularly to his methodology could lead some to believe that all of the information he relays therein is the result of scientific study. The total lack of citation and documentation makes it very difficult to determine to what extent Bailey's claims are based on peer-reviewed scientific evidence. It is true that $T M W W B Q$ 's jacket boasts that it is "based on his original research" and "grounded firmly in the scientific method." And indeed, in some places, Bailey does refer to some of his own actual scientific research. For example, at the opening of the chapter called "In Search of Womanhood and Men," Bailey speaks of "my own recent research [that] has focused on the homosexual type" of transsexual (Bailey, 2003, p. 177). A couple of pages later, he similarly remarks that "In our study, we found that drag queens ranked between gay men and transsexuals on a number of traits related to femininity" (pp. 179-180). But, compared to the organized (and IRBapproved) studies to which he is referring in these two sentences, one would be hard-pressed to call what Bailey did to obtain and present the stories of Kieltyka, Juanita, and the other individuals about whom he wrote "science" - or even "research" in any scholarly sense. Indeed, both Conway and McCloskey have complained about just that-that what he was doing with these women's stories wasn't science-and I think they are absolutely right (McCloskey \& Conway, 2003).

Clearly, what Bailey did in terms of learning and relaying the stories of Kieltyka, Juanita, and other transsexual women was neither systematic nor generalizable. Never did Bailey organize a series of specific questions to ask these women, questions that might have been used, for example, to scientifically test Blanchard's taxonomy. Never did he seek a statistically representative sample of transsexual women in deciding whose stories to tell; again, his critics have complained about just this (see, e.g., Sauer, 2003). He simply picked people who came with good stories-people such as Kieltyka and Juanita - to put human faces on Blanchard's theory. He had no interest in scientifically investigating Blanchard's theory; at this point, he already believed it to be true because of what he had learned from the scientific literature, from colleagues, and from his prior experiences. Using stories in this way is not science-it doesn't even rise to the level of bad science, because it doesn't even pretend to test or develop a theory-and I think it is clear it does not rise to the level of IRB-qualified research by the U.S. federal definition.

Although $T M W W B Q$ occasionally seems to brag about its scientific rigor-especially on its jacket—in the text Bailey frequently acts more like a science journalist than a scientist. He mixes up references to scientific studies he led and stories of individuals he met along the way-stories, remember, not just of transsexual women and crossdressing men, but also of the men on the annual "gay guys" panel of his human sexuality class, of "Princess Danny," and of Edwin, the effeminate man at the cosmetics counter of Bailey's local department store. Bailey didn't get IRB approval to gather or write about any of these stories, because they were all anecdotes and not scientific studies. Given that he consistently obtained IRB approval for work he did that was IRB-qualified, there can be no doubt Bailey knew perfectly well the difference between the anecdotes he used to liven up his book and real systematic and generalizable science. If his readers do not know it, that has certainly been to his and his argument's advantage, but it does not mean he violated federal policy.

Given all this, we have to conclude that, in his interaction with the people whose personal stories appear in $T M W W B Q$-of whom apparently only two (Kieltyka and Juanita) have complained to Northwestern University-J. Michael Bailey did not conduct IRB-qualified human subjects research without IRB oversight.

What about the second seemingly damning claim, the sexual relations allegation? Did J. Michael Bailey have sexual relations with a woman who was his research subject at the time?

Although the answer to this question turns out to be relatively simple, this story bears careful unpacking. In a notarized affidavit reproduced on Conway's site, dated July 21, 2003, Juanita claimed:

On March 22, 1998, Northwestern University Professor J. Michael Bailey had sexual relations with the undersigned transsexual research subject. I am coming forward after I learned he divulged his research findings about 
me in The Man Who Would Be Queen. (Available at Conway, 2003e)

Let's take the second sentence first: Juanita claimed she was coming forward after she learned Bailey "divulged his research findings" about her. This presumably was meant to explain why she had waited a full 5 years to make an issue of the alleged sexual relations: because she was so disturbed in July 2003 by learning that Bailey had written about her in the book, she decided to charge him with improper sexual relations that allegedly occurred one night in March 1998.

The facts say otherwise. Learning that he divulged his "research findings" about her in the book could not have been the impetus for Juanita's deciding in July, 2003, to charge him with improper sexual relations 5 years earlier. In fact, Juanita knew for many years what Bailey was generally writing about her in his book manuscript-indeed, she gave him permission to write about her-and she likely knew for months before the affidavit specifically what he had said about her in the published book.

First, what is the evidence that Juanita gave Bailey permission to write about her-and thus that she knew (for years) that he was writing about her in a book manuscript? Kieltyka-a witness extremely hostile to Bailey nowadays-told me in our interviews that the Northwestern investigatory committee convened in response to their complaints asked both her and Juanita "did you know Bailey was writing a book and did you give him permission?" According to Kieltyka, "Juanita said yes to both, she knew and she gave him permission" (Kieltyka, 2006f). In fact, this giving of permission is confirmed by Juanita's own "sealed" letter (now reproduced on Conway's site) to Northwestern alleging the sexual affair. There Juanita says:

after infrequent "social" meetings with Anjelica and I, Dr. Bailey informed us that he was writing a book about transexuals and would like to include both of our "stories." Believing it to be similar to Dr. Randi Ettner's book, Confessions of a Gender Defender, Anjelica and I gave our verbal consent once Dr. Bailey assured us he would show us what he was writing about us. (Available at Conway, 2003e)

In her "sealed" letter, Juanita goes on to say that what Bailey wrote about her "in an early draft was not objectionable, but absolutely nothing like the spurious and insulting description he wrote about my life that did become part of that most hurtful book of his" (from Conway, 2003e; emphasis added). Kieltyka tells me Juanita was specifically referring to her hurt feelings about what Bailey said about Juanita's wedding and divorce (Kieltyka, 2006c), material that did not appear in the early draft Juanita saw before publication, since Juanita's wedding and divorce post-dated the early draft.
Actually, given how little of Bailey's draft changed from what Juanita saw to what he ultimately published-given that the only substantive changes were about her wedding and divorce-the vast majority of what Bailey wrote about her could not have come as a painful surprise. And most assuredly, she could not have been fundamentally unaware that he was writing about her in his book, as the second sentence of her affidavit suggests. Additionally, and in critical contradiction to the way her complaints to Northwestern read (see Conway, 2003e), Juanita must have known for years that he was writing about her as an example of "homosexual transsexualism." Not only was that claim consistently in early drafts-that, after all, was the whole point of Bailey's writing about herbut in February 1999, in the Daily Northwestern article, student reporter Maegan Gibson reported that in Bailey's book manuscript (the relevant sections of which Gibson also saw), "He classifies [Juanita] as a homosexual transsexual and Anjelica [Kieltyka] as an autogynephilic transsexual" (Gibson, 1999, p. 5). Surely Juanita would have read this feature story about herself; she had been enthusiastic enough about the feature to provide Gibson with her own before-and-afterreassignment photographic portraits, her real before-andafter-reassignment names, and her life story - and so surely in February 1999, from Gibson's article she would have learned, if she really didn't already know it, that Bailey was classifying her as a homosexual transsexual.

Remember also, as noted in Part 4, that on May 22, 2003, several weeks after the book had come out, Juanita joined Bailey, Kieltyka, and others for the social excursion to the Circuit nightclub with Robin Wilson of the Chronicle of Higher Education. In other words, fully 2 months before her affidavit, a document which, in its rhetoric, positions her as newly aggrieved by virtue of just discovering Bailey had written about her, Juanita actively helped Bailey promote his published book by going out and talking with Wilson about what Bailey wrote about her in the book.

To quote one last time the second sentence of Juanita's July 21, 2003, affidavit: "I am coming forward [to charge him with improper sexual relations of 5 years earlier] after I learned [Bailey] divulged his research findings about me in The Man Who Would Be Queen" (emphasis added). Given how many historical documents (including Juanita's own letter to Northwestern) contradict its premise, this second sentence of Juanita's affidavit seems to explain considerably less than the fact that said affidavit was witnessed by none other than Andrea James and Lynn Conway, and the fact that the letter presented to Northwestern along with the affidavit credited "Lynn Conway and Deirdre McCloskey, who have acted on our behalf to make Dr. Bailey accountable for his actions." I think the historical progression here is clear. Juanita knew for years that Bailey was writing about her in his book; she gave him permission and indeed actively helped him; she even 
helped him promote the book after it came out. And then Conway, James, and McCloskey showed up in June and July 2003 to play what appears to have been a significant role in convincing and helping Juanita to charge Bailey with several forms of misconduct-significant enough roles for Kieltyka also to have bothered specifically naming Conway and McCloskey as key witnesses to Juanita's claims in Kieltyka's own July 2003 affidavit about the matter (Kieltyka affidavit, July 23, 2003; available at Conway, 2003e). For the record, I asked McCloskey, "What exactly was your role in preparing the formal, written charges made by the woman known as Juanita that Bailey had had sexual relations with her when she was his research subject?" She answered only "Not much" (p.e.c., January 22, 2007). She declined my request to elaborate (p.e.c., February 4, 2007).

Even if Juanita was not in July 2003 the shocked and disillusioned party that the second sentence of her affidavit suggests, what of the core claim as reported in the first sentence of the affidavit: "On March 22, 1998, Northwestern University Professor J. Michael Bailey had sexual relations with the undersigned transsexual research subject." In her July 23, 2003 letter to Northwestern University's C. Bradley Moore, charging Bailey with having had sex with her, Juanita recounted more precisely the alleged circumstances:

Dr. Bailey met Anjelica Kieltyka and myself earlier that same evening [March 22, 1998] into morning at "Shelter", one of the night clubs frequented by female transexuals. The date is well remembered because it was "Shelter's" final night before closing for good. I arrived at the club with Ms. Kieltyka, but left with Dr. Bailey. Ms. Kieltyka can confirm this. Dr. Bailey then drove me back to my place, where the sexual relations occurred. [...] I have told no one about the sexual relations other then [sic] you, Dr. Moore, my best friend and confidante, Charlotte Anjelica Kieltyka, and Professors' [sic] Lynn Conway and Deirdre McCloskey, who have acted on our behalf to make Dr. Bailey accountable for his actions. They will provide sworn affidavits supporting my claims. (available at Conway, 2003e)

Juanita is thus quite specific: She and Bailey had sexual relations on the night of March 22, 1998. What of Bailey's response to this claim?

In his online self-defense piece, "Academic McCarthyism," published in October 2005, Bailey countered with this: "her 'complaint' is not true. The alleged event never happened. If I ever needed to do so, I could prove this, but there is no reason why I should" (Bailey, 2005). Bailey's reasoning for why he should not have to prove he didn't have sex with Juanita was twofold: first, he "insist[ed] that Juanita was not a research subject" when she claimed they had sex; second, "there is nothing intrinsically wrong or forbidden about having sex with a research subject[....] Some of my colleagues have had sex with their research subjects, because it is not unusual to ask one's romantic partner to be a subject" (Bailey, 2005).

Temporarily putting aside the question of that twofold defense (Juanita wasn't a research subject and there's nothing intrinsically wrong about having sex with a research subject), I told Bailey I thought the reason he should prove he didn't have the sexual relations Juanita claimed is because many people found the claim to be the nail in the supposed coffin of his professional reputation. I pressed Bailey to answer two questions for me: Did he in fact have sex with Juanita? And if not, why had he for several years - until his 2005 "Academic McCarthyism" self-defense—refused to publicly answer her charge?

$\mathrm{He}$ explained simply the delay in denying the charge: About the time Juanita's sexual relations allegation appeared, Bailey's lawyer had advised him to stop publicly answering any questions about the controversy. Indeed, the record confirms that the sexual relations allegation is not the only thing to which Bailey refused to respond starting in the summer of 2003; he did not defend himself publicly on any of the charges made against him until "Academic McCarthyism" in October, 2005 (Bailey, 2005). Bailey also explained to me that he understood that there was no way to answer Juanita's claim without at some level legitimizing her claim; he believed (correctly I think) that acting as if what she claimed mattered by protesting repeatedly against it would only backfire and work against him in the court of public opinion (Bailey to Dreger, p.e.c., July 18, 2006). Could he really, in 2003, say "I did not have sex with that woman" and hope to have his public reputation thus exonerated?

Nevertheless, given that he had come around in 2005 to denying Juanita's claim, I pressed him on what his denial ("The alleged event never happened" [Bailey, 2005]) really meant: Was he using a Clintonian definition of sex, or evading the central question in some other way? Did they have sexual relations on some other day, or perhaps have some kind of non-intercourse physical contact that a reasonable person could define as "having had sexual relations"? No, he said, he had never engaged in anything with Juanita that could reasonably be called sexual relations. He did admit to me that he had flirted with Juanita once or twice when they were out socializing, but he insisted that was the limit; he had never had or even attempted any sexual relations with Juanita (p.e.c.'s, July 19, 2006). I then pressed him for the proof that it never happened - the proof he alludes to in "Academic McCarthyism" (Bailey, 2005). And he produced it (p.e.c., July 20, 2006). When I read it, it struck me ironically as about the least sexy proof one could provide.

Bailey explained to me that, when Juanita made the sexualrelations charge to Northwestern in 2003, in order to defend himself, knowing it never happened, he immediately looked up his computer records to see whether he could prove his 
claim. He quickly discovered that, on March 22, 1998, his exwife Deb Bailey had been out of town on her spring break and he was, by their annual arrangement, staying at her house taking care of their children, who were then aged 11 and 13. He provided me what he had offered Northwestern: records of back-and-forth conversations between him and Deb Bailey that week, covering all the mundanities of taking care of house and children (provided in p.e.c., Bailey to Dreger, July 20, 2006). In these, Deb Bailey reminded Michael Bailey to feed the fish, the hamster, and the cat, to clean out the litter box, to bring in the newspaper and the mail, to take the kids to their after-school activities, and so on. These documents evince at least that on March 22, 1998, Michael Bailey was singleparenting his two children (and their many pets) in Evanston. I asked him if he might have left the children in Evanston, perhaps with a sitter, and gone out with Kieltyka and Juanita to the Shelter nightclub into the small hours of the morning, but he was adamant that he would never have left his children to go out to bars while his ex-wife was across the country and it was his turn to parent (p.e.c.'s, July 19, 2006).

For confirmation, I put Michael Bailey's claims to Deb Bailey, and she checked her records and confirmed that on March 22, 1998, Michael Bailey was single-parenting in Evanston while she was away. She also (with some embarrassment) confirmed the elaborate household instructions she gave him for that period, independently providing me a copy of some of the same correspondence Michael Bailey had provided me. When I asked her if she thought it possible that Michael Bailey would have gone out to a Chicago bar when he was supposed to be taking care of their children in Evanston while she was away, Deb Bailey said she found it unfathomable given his record as a devoted and attentive father. She made it politely clear that she has no illusions that Michael Bailey is a saint, but she also finds it impossible to believe that he would have been out with Juanita on the night she claimed, especially given that there were plenty of other weeks of the year in which he could have done just that (Deb Bailey, 2006; Deb Bailey to Dreger, p.e.c. January 7, 2007).

If Michael Bailey is telling the truth-that he and Juanita never had sex-why does Juanita's account so clearly say otherwise? I asked Kieltyka to tell me what she knew about the alleged relations and the charge, since she supposedly had been with Bailey and Juanita on the night in question and she had been present for at least some of the sessions in which Conway and McCloskey apparently helped to arrange the charge (Conway, 2003e; McCloskey to Dreger, p.e.c., January 22, 2007). According to Kieltyka,

[Juanita] told me the day after Bailey drove her home from the Shelter nightclub that Bailey had tried to do something .... That they had "messed around"-She was being slightly evasive and uneasy so I left it alone. [Five years later, in the summer of 2003] when Lynn
Conway [was] over at my house, Juanita was there, and that's when she told the two of us that Bailey in fact had had sex with her. This was the first time that I found out it wasn't that he had "tried something" - it was that he had tried to have sex with her. But that he couldn't get it up. (Kieltyka, 2006c; ellipses in original)

This came as surprising and important news to me-that what Juanita had apparently meant in her affidavit and her sealed letter to Northwestern by "sexual relations" was "he had tried to have sex with her but that he couldn't get it up." The story about what even happened seemed to keep changing. So I pressed Kieltyka further:

Dreger: Why did she say [in the affidavit and the letter] they had sex, if he couldn't get it up?

Kieltyka: What are you-his lawyer? What's your definition of sex?

Dreger: The fact that he tried? That's the definition of having had sex?

Kieltyka: What did Clinton have?

Dreger: Clinton got it up. [...] So you're saying she said he tried but he didn't get it up?

Kieltyka: Right.

Dreger: And she told that to Conway and McCloskey.

Kieltyka: Right.

Dreger: And then [in the formal charge] to Northwestern she said that they had had sex.

Kieltyka: I'm not sure what the letter says....I think it says "sexual relations"_-just like El Presidente Clinton. [...] It all is a matter of a definition of what sexual relations is. Because there was fingering, that she was giving him a hand job, I don't recall exactly. Anyway [...] from the moment that Andrea James and Conway wanted to use the sex with a research subject as a way of getting Bailey, I wasn't enthusiastic[.] (Kieltyka, 2006c; ellipses in original unless bracketed)

Nevertheless, the national press was enthusiastic about this part of the Bailey controversy. Conway handed over the socially and professionally damning charge of "sexual relations with a transsexual research subject" to any reporter who would take it. And, while Bailey's accuser's identity remained protected almost as if she were a rape victim, while his accuser apparently remained privately inconsistent about what even happened, while Bailey felt unable to defend himself publicly because of his lawyer's gag order and the realities of postLewinsky sexual politics, many reporters broadcast the charge along with Bailey's refusal to respond (e.g., Barlow 2003; Wilson 2003c) to the serious detriment of Bailey's personal and professional reputation. By the time I came to this work in 2006, when I asked people what they knew about what Bailey had supposedly done wrong, the majority told me that he had had sex with a research subject. 
Yet, given the facts, we must conclude that Bailey was right when, in 2005, he made the rather dull (and thus generally ignored) legalistic point that, all other questions aside, Juanita was simply not his research subject in March 1998, at least not in any meaningful sense of research. Even if Bailey had started thinking by March 1998 that he might eventually write something about her (which documents suggest was not the case until the summer of 1998 when she agreed to meet him over coffee to talk about her story for the book), I don't think this made her a "research subject." I don't think we can call everyone from whom a scholar may learn a story she or he eventually may recount a "research subject." Otherwise, given how often we scholars write about conversations we've had and observations of people we've met along the way, we're going to have to count nearly everyone we know and meet as an actual or potential research subject. (And in that case I confess I've repeatedly had sex with a research subject, namely my husband, about whom I've written quite often, and generally without first asking his permission-for instance, right now.)

I have come to conclude Bailey was also right when, in 2005, he made the point that no one-not even his friends and defenders-wanted to hear, i.e., that there's nothing necessarily wrong about sex with a research subject. Although I had the initial knee-jerk reaction shared by many- "sex with a research subject is verboten"-I've come to realize people's revulsion to sex-with-a-research-subject represents a more general (and irrational) revulsion to non-standard sexual relations. If a researcher abused a position of power to coerce a research subject into sex, that would be wrong, but sexual coercion is wrong regardless of the relationship, and it is certainly not the case that all researchers hold all subjects in disempowered (and thus potentially coercive) positions. Indeed, it is easy to imagine a situation where the reverse could be true, i.e., where a subject would hold real power over the researcher rather than the other way around. I have heard the claim that sexual relations will necessarily interfere with data collection because of the problem of dual relationships, but again, this isn't necessarily the case with all research. It's hard to imagine, for example, how data collection would be compromised if a researcher studying the effects of a particular drug on cholesterol levels had sex with one of the subjects whose cholesterol levels she was tracking.

In the specific case of Bailey and Juanita, I believe we have to conclude that, even if one does believe that sex with a research subject is always unethical (which seems seriously wrongheaded), and even if one believes Bailey and Juanita had sex on March 22, 1998 (which seems unlikely), the salient point here is that Juanita was not Bailey's research subject in March 1998, when she claims they had sex. In other words, even if any sexual relations occurred between Bailey and Juanita on March 22, 1998, they were not improper relations by any reading of ethics-of-sex-with-research-subjects, because Juanita was not Bailey's research subject in March 1998, when she claims the relations happened.

Even after this conclusion, the curious may still wish I could tell them for sure whether the alleged sexual relations happened. I must leave it to readers to make what they will of what I have uncovered regarding the nature and timing of Juanita's story (or stories), and to also decide what to make of the roles of Conway, James, and McCloskey in the formal production and broadcasting of the injurious claim. From the vantage point of this inquirer, it certainly looks as if the allegation-particularly the choice of the conveniently vague phrasing "sexual relations" combined with otherwise highly specific details about the when, the where, and the who of the supposed event-amounted to a trumped-up attempt on the part of a small circle of Bailey's transwomen critics to damage his professional reputation. To some extent, it worked, in large part because it cleverly took advantage of the sex-negative attitude that pervades American culture, including the particular cultural phobias that surround transwomen such as Juanita. As Bailey remarked to me, "it was deeply ironic that Conway et al. were trying to sensationalize sex with transsexuals," but it seemed they would do even that to try to get back at Bailey for the claims he made in his book (Bailey to Dreger, p.e.c., July 19, 2006).

When Kieltyka told me she "wasn't enthusiastic" about the sexual relations charge, it was to emphasize that what she found truly unethical was what she called Bailey's "bait and switch" tactics:

he was using friendship as a context for what he wanted, there was a duplicity, there was a deception. It was a misuse of our friendship and relationship. [...] And not only that, $[\ldots]$ saying that he was writing a book, and us agreeing [to that] on one set of values and terms, and for him to switch it, and to present it to us, and for us to understand we were misused, it was too late for us to do anything about it because he intended all along from the get-go to use that information. (Kieltyka, 2006c)

On another occasion, Kieltyka put the same sort of complaint to me this way: "It now seems Bailey ingratiated himself to me and the transwomen I brought to him: Entering our favor in order to take advantage of us......gaining our friendship and confidence-playing a conjob on us......using and abusing our vulnerability" (Kieltyka, 2006a; ellipses in original).

What then of this claim of unethical behavior? Did Bailey abuse the trust he established with the transsexual women about whom he wrote in TMWWBQ, essentially tricking them into revealing otherwise private information about themselves, so that he could use them as "poster children" for Blanchard's taxonomy in his book?

The first thing one has to understand in considering this question is that the two women who complained about Bailey's 
account of them in $T M W W B Q$, namely Kieltyka and Juanita, could not seriously be said to be deeply private and "living in stealth" as McCloskey and Conway insisted in their complaints to Northwestern's Vice President for Research (McCloskey \& Conway, 2003). At the risk of beating a dead horse, let me note again that, by the time $T M W W B Q$ was published, Kieltyka and Juanita had presented themselves, their life histories, and their takes on transsexualism to a total of thousands of students at Northwestern University. Kieltyka had even concluded twice by stripping naked (she says to make the point that transsexual women can be extremely attractive even in the nude [Kieltyka, 2006a]). Juanita was apparently also not shy about appearing nude; after all, from at least June, 2003, to December, 2004, Conway's site featured the semi-nude erotic photo of Juanita taken by Kieltyka (Kieltyka, 2003a). Remember also that, in 1998, Kieltyka and Juanita had given Maegan Gibson their true, pre- and post-reassignment first and last names, their preand post-reassignment photos, and their life histories to broadcast in the Daily Northwestern (Gibson, 1999). Before this, Kieltyka had revealed parts of her transsexual story to a local paper, Berwyn Life, and on a local cable channel (Kieltyka, 2006a). Then in 2002, in response to a request from Bailey, Kieltyka and Juanita again teamed up to talk openly about themselves, their bodies, and their sex lives for a video made to accompany a human sexuality textbook. In that video recording, besides both of them again allowing a publisher to use their true first names and unobscured faces, Kieltyka showed off her pre-transition, crossdressing, erotic-play props, and Juanita talked about making a living as a sex worker both pre-op (as a "she-male") and post-op. In the video work, each of these women also openly recounted significant portions of what Bailey's book would say about them a year later (edited version at Allyn \& Bacon, 2004; uncut interview footage provided from Bailey's personal files). Then, shortly after meeting Conway in the summer of 2003, Juanita let Conway put up five close-up photos of her along with her story-again matching much of what Bailey said about her in the book-on Conway's Transsexual Women's Successes page (Maria, 2004).

In short, Kieltyka and Juanita were not "stealth" shrinking violets whose stories were sneakily gathered and then first broadcast in 2003 by Bailey. Given how many times Kieltyka and Juanita willingly revealed themselves again and again, Bailey concludes "I believe the claim is absolutely false- the claim that they didn't want any of this public" (Bailey, 2006a). Trying to explain away the repeated classroom presentations (for which, remember, Kieltyka and Juanita were paid), McCloskey and Conway claimed to Northwestern that "Professor Bailey enticed the women into his classrooms under the pretense of listening open-mindedly to their views" (McCloskey \& Conway, 2003). But even if Bailey really had been faking open-mindedness throughout their relationships, he surely wasn't forcing Kieltyka and Juanita to talk about their lives and show themselves off again and again. To suggest, as McCloskey and Conway do, that these women had no agency in their work with Bailey, no ability to decline him, is to treat them as children. They were not.

Might there be some other sort of way in which Bailey abused the trust of the transsexual women about whom he eventually wrote in $T M W W B Q$ ? Kieltyka told me that Bailey had violated both trust and confidentiality by using what the transwomen she brought to him had told him in the interviews he conducted for purposes of writing letters in support of their SRS requests (Kieltyka, 2006c). Out of the four women who filed charges with Northwestern claiming Bailey used them as research subjects without their knowledge and approval, three had obtained letters from Bailey supporting their requests for SRS (Conway, 2003c, 2003d, 2003f). (Kieltyka was the fourth complainant; she was post-transition when she met Bailey.) The three women in question all claim in their complaints that Bailey used what he learned during their SRS-letter interviews for his "research." What about this?

Bailey denies it. He points out that two of the women in question are not even mentioned in $T M W W B Q$; thus, it is unclear how they think he used their SRS-letter interviews for his so-called "research". As for the third woman, namely Juanita, Bailey says he did not use her SRS-letter interviews for the book; he says he used what he learned from her outside the context of those interviews (Bailey, 2006a, 2006c). It is impossible to confirm whether this is the case. But what we do know is that, according to Kieltyka, Juanita acknowledged to the Northwestern investigation committee that Juanita knew Bailey was writing about her and that she had given her permission for him to do so (Kieltyka, 2006f), and that, according to Juanita, both Kieltyka and Juanita knew Bailey was writing about them and gave them permission to do so (see "confidential addendum to item 2, submitted in sealed envelope," at Conway, 2003e). It is also clear that Bailey had plenty of contact with Juanita outside the SRS interviews - in her class presentations, in a book-related coffee appointment in August 1998, in their social outings, and in her participation in the 2002 video. Maybe he did use in the book what Juanita told him during the SRS interviews, but it doesn't look as if he would have needed that material as a source. She seemed perfectly willing to be open about herself with him and others on many other occasions.

What then about Kieltyka's claim that Bailey pulled a "bait and switch" by leading her and her friends to believe he would write about them favorably only to turn around and-to her mind pejoratively-label them either autogynephilic or homosexual transsexuals? Being used by Bailey as someone who "openly and floridly exemplifies the essential features of [...] autogynephilia" (Bailey, 2003, p. 156) is clearly the source of much pain for Kieltyka, understandably so since she was taken to task by some transwomen for "allowing" Bailey to "use" her as an example of a theory they find wrong, 
harmful, and even disgusting. Kieltyka told me several times that she believes Bailey's portrayal of her as an "autogynephile" constitutes "subreption," i.e., a misrepresentation of her identity so absolutely gross as to constitute a virtual theft of her true identity (Kieltyka, 2006a, 2006b). It was Bailey's identification of her in this way, she suggested, that led to the change of her reputation in trans circles, from a devoted friend and advocate of transwomen to a source of potential or actual harm to those same women.

As I have already shown, Kieltyka and Juanita knew many years in advance of 2003 that Bailey was writing about their lives in a manuscript and also that he classified Kieltyka as an autogynephilic transsexual and Juanita as a homosexual transsexual. Kieltyka even admitted to me that "these terms 'homosexual' transsexual and 'nonhomosexual' transsexual [...] Bailey used [them] on the SRS letters" for Juanita and the other women, though, according to Kieltyka, "none of us noticed, let alone understood the implications of those classifications" (Kieltyka, 2006a). But at least Kieltyka had to have noticed and understood the implications by the time of Gibson's 1999 article, because there Gibson wrote, "Bailey believes Anjelica is an autogynephile, but Anjelica adamantly disagrees with the way he categorizes her. While she does believe autogynephiles exist, she doesn't consider herself one" (Gibson, 1999, p. 5).

Indeed, evidence shows that Kieltyka noticed and was bothered by her labeling as autogynephilic even sooner, in late 1998. In an email message Bailey wrote to Blanchard in early December 1998, Bailey told his colleague, "I showed the [relevant manuscript] section to Anjelica (the autogynephilic transsexual who is most in the book), and she is upset. Not that the facts were wrong, but she doesn't like my interpretation and the intimation that she is not a woman trapped in a man's body. I talk to her tomorrow; not looking forward" (Bailey to Blanchard, p.e.c., December 2, 1998). In fact, both Bailey and Kieltyka recall Kieltyka's being upset during that conversation-not about Bailey writing about intimate details of her life, but about his labeling her masculine and autogynephilic (Bailey, 2005; Kieltyka, 2006b). Then just a couple of months later, Gibson aired Bailey's classification of Kieltyka (Gibson, 1999). That couldn't have made Kieltyka any happier, and it surely couldn't have caused Kieltyka to think Bailey was budging on his claim about her identity.

Why, then, did Kieltyka keep associating with Bailey, year after year, even though he seemed to keep labeling her autogynephilic, a diagnosis of which she knew and to which she objected? I put this to Kieltyka — why did she keep going to his classes, socializing with him, introducing him to other transwomen, helping in response to his request regarding the human sexuality textbook video, and so forth, if she was upset with his labeling her an autogynephile?

Kieltyka had two parts to her explanation. First, to put it simply, she valued her relationship with Bailey and didn't want to abandon it. She explained the same was true for many of the other transwomen she introduced him to: "all those years, all these women that volunteered to lecture [for pay in his classes] did it because they were still friends with me and also because they respected Mike Bailey and trusted him, [they trusted] that Bailey saw them the way they saw themselves" (Kieltyka, 2006b). Kieltyka in particular believed Bailey saw her as an intellectual and professional collaborator. In fact, as noted in Part 2, for some time she believed she would be something like a co-author on the book he was writing (Kieltyka, 2006b). She came to see "Bailey as a mentor or almost like the relationship between a grad student and a professor, or even like a daughter and a father" (Kieltyka, 2006b). She recalls "I was getting validation [from Bailey] as a researcher, as a field operator, as someone who had large contacts within the community. I felt I was working as a consultant and a collaborator" (Kieltyka, 2006b). Apparently, it didn't seem worth giving all that up over what she saw as his misdiagnosis of her.

The second reason Kieltyka says she kept working with Bailey, even after she knew he had labeled her an autogynephile in his manuscript and in Gibson's article, was this: After she expressed her distress over his diagnosis of her, he told her he remained open to any evidence she could present that he was wrong. And she believed that, if she stuck with the relationship, she could convince him he was wrong about her. She recalled to me that after she saw his manuscript where he wrote about her as an autogynephile, "he said this is a first draft, we can use any information to support your theory if you have support for your theory. If you can change my mind, that's all part of our relationship[.... What I saw was a misunderstanding or a misinterpretation, [and] I wanted the opportunity to change his mind" (Kieltyka, 2006b). Kieltyka tells me she eventually came to believe that the opportunity to change Bailey's mind came in the form of a sexual arousability study Bailey's lab was conducting, and so she helped recruit transwomen subjects for that study. The study sought to explore whether sexual arousal is category-specific in females as it is in males. Bailey and his colleagues specifically wanted to know whether homosexual and heterosexual natal men, homosexual and heterosexual natal women, and MTF transsexuals demonstrated genital arousal to male sexual stimuli (i.e., erotic images of men), to female sexual stimuli, or to both.

Kieltyka told me she was convinced that the study would show Bailey what she believed to be true: that transsexual women such as herself (i.e., those primarily attracted to women) would show genital arousal to other women. In other words, she believed the study would show Bailey that women like her are gynephilic, and not autogynephilic (Kieltyka, 2006a, 2006b). And indeed she believes the results did demonstrate just that, because the women like her showed clear category-specific genital arousal patterns to the female stimuli (Chivers, Rieger, Latty, \& Bailey, 2004). 
I asked Bailey about Kieltyka's interpretation of this study, and he explained that the study was never designed to be a critical test of Blanchard's theory of autogynephilia, because the study included no clear assessment of whether "nonhomosexual" transsexual women are or are not erotically aroused by the idea of being or becoming women; to his mind, the study simply showed that nonhomosexual transsexual women are aroused by erotic pictures of women-not why they are, nor whether other women are the primary source of their arousal, nor what is the motivation for their transitions. More importantly, Bailey said Kieltyka never gave him any sense that her recruitment of transwomen to the study was motivated by her desire to disprove Blanchard. His understanding was that she was simply interested (as he was) in having his lab study the arousability of transwomen like her (Bailey to Dreger, p.e.c., January 17, 2007).

All in all, given the substantial historical record of their collegial associations, it makes sense that Kieltyka got a lot out of her relationship with Bailey and that consequently she wanted to try to make it work in spite of their continuing disagreement over her identity. It also makes sense that she would try to talk him out of labeling her an autogynephile, and that she would choose to believe that, as she says he claimed, he remained open to contrary evidence-although it is also clear he would have required truly extraordinary evidence to seriously doubt Blanchard's theory and the peer-reviewed scientific evidence for it, especially when virtually everything Kieltyka and her friends told him about themselves seemed to him only to back up Blanchard's theory.

One has to suspect that, had the intervention of Conway and her fellow "investigators" never happened, Kieltyka and Bailey might well have continued to have a relatively congenial relationship even while Bailey continued to label Kieltyka an autogynephile, against her sense of self. I say this because of the friendly emails that continued after Kieltyka had seen a copy of Bailey's book. For example, recall that on May 16, 2003, several weeks after she received the book and just after the backlash had started, Kieltyka jokingly offered to lend Bailey her old athletic support for his next book signing or lecture, and signed the email "Your friend, in spite of spite" (Kieltyka to Bailey, p.e.c., May 16, 2003). But the intervention of Conway and company did indeed happen, and once it did, Kieltyka painfully came to see how, via Bailey's portrayal of her as an autogynephile and the ensuing backlash against $T M W W B Q$, her personal identity was fast being reconstructed by people like Conway and James. She was being actively transformed from a well-liked local trans advocate to a national pariah in the realm of trans rights. And so she came to believe she had been used and abused by Bailey; and she came to believe he had been pulling a con job on her and her friends all along. For his part, he was stunned and then angry at how, after years of a friendly relationship in which he often helped her and her friends, she turned so viciously on him (Bailey, 2006a).
So, to return to the question posed at the outset of this discussion: Did Bailey abuse the trust he established with the transsexual women about whom he ultimately wrote in $T M W W B Q$, essentially tricking them into revealing otherwise private information about themselves, so that he could use them as "poster children" for Blanchard's taxonomy in his book? A total of two women-Kieltyka and Juanita-have complained personally of this sort of treatment. I think it is clear that, in fact, both opted to reveal intimate details about themselves publicly again and again, and both of them knew, or surely should have known, that Bailey was very likely if not certain to write about them as examples of Blanchard's taxonomic types. It is also clear Kieltyka repeatedly objected to the characterization of her as an autogynephile, and it seems likely that, through his words and actions, Bailey let Kieltyka wishfully believe she might change his mind about that when, in fact, there was little chance of her doing so. If Bailey falsely put forth an image of being likely to be swayed by Kieltyka's critiques as a way of drawing more intimate information from Kieltyka and her friends about their sexualities and their lives, that would be wrong. But I can't find any evidence that this is how he came to know the intimate details of Kieltyka's life or the lives of her friends; rather, he seems to have obtained those because Kieltyka, Juanita, and indeed several other transwomen in their circle were generally forthright and unashamed about themselves in their presentations and their conversations with Bailey.

A subsidiary question to consider in the context of this discussion is this: Did Bailey write about Juanita and Kieltyka without their permission, as they claimed in their complaints, and if so, was that wrong? As noted above, it appears that, at least early on, both Juanita and Kieltyka gave Bailey permission to write about them-gave permission explicitly (according to what Kieltyka said about their testimonies to Northwestern and what Juanita said in her "sealed" letter to Northwestern) and implicitly (judging by the fact they helped Bailey by answering questions when he told them he was writing about them in the manuscript). Notably, although he did obtain their permission, according to commonly accepted ethical standards, Bailey was not required to obtain or even seek Juanita's and Kieltyka's permission to write about them; it is not uncommon for scholars to relay stories without asking permission of subjects, particularly when their identities are protected. Now, was it obnoxious of Bailey to write of Juanita and "Cher" as examples of Blanchard's two types without obtaining their permission to do that specifically? One can see why the subjects themselves might feel that way. But I think one must also appreciate that scholarship (like journalism) would come to a screeching halt if scholars were only ever able to write about people exactly according to how they wish to be portrayed.

I said above that it is not uncommon for scholars and journalists to relay stories without ever asking permission of subjects, particularly when their identities are protected. But 
one of Kieltyka's complaints is just that-that Bailey failed to adequately protect her identity, leaving her personally open to criticism and profound misunderstanding. What about this? Did Bailey fail to adequately protect his subjects' true identities?

No person aside from Kieltyka has alleged that his or her identity was inadequately protected in $T M W W B Q$, so I focus here on Kieltyka. In his self-defense piece "Academic McCarthyism," Bailey claims "It was [Kieltyka] who compromised her own anonymity, in her [May 4, 2003] email to Conway," an email Conway quickly put up on her Website (Bailey, 2005). But after I listened to Kieltyka's version of the story, I told Bailey that Kieltyka said that by the time she contacted Conway in early May 2003, Conway already knew she was Cher. Kieltyka told me, "They were about to hang me. I was told this by people that had frequented the Internet, and that's why they gave me the link to contact Andrea James and Lynn Conway, because I was going to be hanged by them" (Kieltyka, 2006f).

How did James and Conway figure out who Cher was? In the preface to $T M W W B Q$, Bailey thanks Anjelica Kieltyka for "introduc[ing him] to the Chicago transsexual community" (Bailey, 2003, p. xii), and then much later says that "most of the homosexual transsexuals I have met, I met through Cher" (Bailey, 2003, p. 177). Even given this mirroring of acknowledgements, I think it is safe to say the average reader, unfamiliar with the trans scene, would have been unlikely to figure out from Bailey's book that "Cher" was Kieltyka, especially given that in the preface he separately thanks Kieltyka and Cher as if they were two different people (pp. xii-xiii). But Conway and her co-"investigators" were not average readers. Kieltyka notes that Bailey revealed that Cher plays the hammered dulcimer in an Irish folk group (Kieltyka, 2006c; see Bailey 2003, p. 155). A number of people in Kieltyka's local communities, including presumably neighbors and various associates in Chicago transwomen circles, knew about Kieltyka's transsexuality as well as her musical life. Given the hammered dulcimer reference as well as the extent to which Bailey's description of Cher matches Kieltyka's personality and personal life_-about which she had been very public_-it would not have been too hard for Conway to ask around and find out who this "Cher" was (Kieltyka, 2006c). It is also possible-even likely_that Conway or a member of her cohort was Web-savvy enough to find archives of the portion of Bailey's Northwestern site where in 1998 he had put up the part of the manuscript where he described Kieltyka, identifying her at that time by her real name. (Bailey states he had put this material up for his human sexuality students to read. It never occurred to him that it could or would later be found by others [Bailey, 2006a].)

When I asked Bailey about whether he thought he had failed to protect Kieltyka's identity, and whether he regretted that, he explained,
I had originally asked her to help me pick a pseudonym for her, and she asked me to use her real name. I still remember her saying: "I am not ashamed of anything I've ever done." I admired that. It was only after she read the initial draft, and especially my interpretation of her behavior as autogynephilic, that she changed her mind on this. (Bailey to Dreger, p.e.c., January 17, 2007)

He continued, "Because Anjelica Kieltyka had so publicly given her story to so many people (including not only my class but to transgender groups in Chicago), I felt no legal or ethical obligation to mask her. I changed her name because I liked her at that time and because she requested it." According to Bailey, "She only requested that I change her name, and not that I mask her" by changing other details that might identify her (Bailey to Dreger, p.e.c., January 17, 2007).

It is entirely possible, given her personality and especially her persistent interest in being public about herself, that Kieltyka might have decided to out herself as the woman who was Cher sometime after the book came out if Conway's "investigation" had never begun. But Kieltyka never had the option of deciding that, since Conway and James quickly flushed her out. I do not believe Bailey intentionally outed Kieltyka as Cher, so I don't think we can call his behavior in this case unethical in any simple fashion, though he might have thought more carefully about changing more of her personal identifying information, especially given that he knew she didn't want to be called an autogynephile. I understand why Kieltyka is so angry that she came to be seen, based on Bailey's portrayal of her and the backlash-reading of that portrayal, to be a cause of harm to the very women for whom she saw herself as an advocate. It must have been-and still must be-truly painful to feel that her core identity has been misrepresented over and over again.

Four final charges made against Bailey must be considered before we close this inquiry into the merit of the claims that Bailey behaved unethically, illegally, or immorally in the production of his book. I believe all four can be dispensed with rather quickly.

First, did Bailey fabricate the ending to the "Danny" story to show that Danny (and most boys like him) would end up gay instead of transsexual (Bailey, 2003, pp. 213-214)? Conway claims this on her site and bases the claim solely on a report from Kieltyka that Bailey admitted this to Kieltyka (Conway, 20031). When I asked Bailey about the matter, he responded: "I changed things [in the ending story about Danny] to prevent identification. In fact I' $m$ not sure that, if Danny read the book, that he would say 'oh, that's me.' But the essential story at the end of the book is true. To tell you more about what that means would compromise the anonymity that I'm trying to maintain" (Bailey, 2006a). He added, "Lynn Conway says that, by the way, [solely] on the basis of what Anjelica told her, and I'd like to know if Lynn Conway thinks everything Anjelica says 
is true" (Bailey, 2006a). In fact, I can find no evidence that Bailey fabricated anything meaningful in Danny's story or in the story of anyone else in the book. It is worth noting again that even Kieltyka has never disputed any of the facts Bailey related about her and her life; she disputes only his interpretations.

Second, was Bailey illegally practicing clinical psychology without a license when he provided letters in support of a few local transwomen's requests for SRS? This may not really be a point germane to an inquiry into the production of $T M W W B Q$ since Bailey says he did not use the SRS interviews as the basis for the stories in his book, but let's assume for the moment that he did, and answer the question anyway. After all, Conway, James, and McCloskey each filed formal complaints with the Illinois Department of Professional Regulation and Northwestern University accusing Bailey of illegally practicing psychology without a license by providing the SRS-support letters (Conway, 2004d).

A quick check of the laws of the state of Illinois reveals that, in fact, Bailey was not practicing illegally, because he never asked for or received money (or anything else) in exchange for producing the SRS-support letters, and the relevant Illinois state regulations indicate that if a person does not seek or obtain "remuneration" for services offered or rendered, that person is not required to have a license, even if the person otherwise appears to be offering what counts as "clinical psychological services" (225 ILCS 15/1 [from Chap. 111, para 5351]). Bailey also never offered or represented a therapeutic relationship with any of the women in question. Presumably this is why the Illinois Department of Professional Regulation never seems to have bothered pursuing the charges made against Bailey.

As a side point, let me just note the irony in Conway's, James's, and McCloskey's trying to use Bailey's SRS-support letters against him. It certainly appears from this vantage that, in answering Kieltyka's call for help for her marginalized transwomen friends by providing letters in support of their requests for SRS - free of charge and without any requirement of a lengthy and costly "therapeutic" relationship-Bailey was helping to reduce the barriers to transition for a small number of transwomen, the very barriers about which people such as Conway, James, and McCloskey have complained (see, e.g., Conway, 2006b; James, n.d.-g; McCloskey 1999, pp. 71-72). One can imagine, in a different situation-say, one in which the psychology professor in question didn't believe in Blanchard's taxonomy-the likes of Conway, McCloskey, and James holding up Bailey as a model for his support of these women's pursuit of SRS.

Third, was Bailey undermining the rights of sexual minorities, including transsexual women, by producing the book he did? As I've noted, this claim has been made again and again by Conway, McCloskey, Kieltyka, and others, including to the press, on the Web, and in letters and emails to
Bailey's colleagues in the Northwestern Psychology Department. But it isn't clear that Bailey's book does undermine the rights of sexual minorities, any more than it is clear that it supports them. Yes, he points to the relative femininity of many gay men, and that reiterates a classic stereotype, but he also makes clear he believes there's nothing wrong with being a relatively feminine man or a gay man. Yes, he labels some transwomen as having a paraphilia-namely autogynephilia-but he also clearly says it is not harmful and that the only real consideration with regard to SRS decision-making is the happiness of individual transwomen. If it makes them happier (and he says it does), then they should be able to get it. As I think I showed clearly in Part 3 of this essay, Bailey's book is complicated and often atypical in its claims, and this is probably why different readers have read $T M W W B Q$ quite differently. Public critiques as well as correspondence Bailey has received (like correspondence I myself have received) suggest that some queer people find his book part of the problem of social oppression of queer people, while others see in it personal liberation through his finally giving voice to politically incorrect truths about their queer identities.

Notably, because it is often scientifically and politically atypical in its claims, Bailey's work seems particularly inclined to create critics and allies on all sides; so, for example, we've seen how he was criticized and praised in both the left-wing and right-wing media. And we find the anti-gay National Association for Research \& Therapy of Homosexuality (NARTH) trying, largely through highly selective quotation, to use Bailey's words on homosexuality to defend their homophobic policies (see, e.g., Byrd, 2006) even while Bailey has been reasonably positioned to debate against NARTH representatives on a Catholic radio program and in academic conferences on homosexuality. So I think it is a serious intellectual challenge to make the claim that Bailey is simply anti-queer or even anti-trans in his book. I see no evidence the book is, as Kieltyka has suggested, part of a widespread, undercover agenda to eliminate queer people through eugenics and other biotechnological means. And, after my exegesis of $T M W W B Q$ as presented in Part 3, I find it impossible to analogize the book to Mein Kampf, as McCloskey has done (McCloskey to Marks, p.e.c., February 3, 2004, available at Conway, 2005a).

Finally, did Bailey ignore critical data against Blanchard's theory, so that he was essentially engaged in the suppression of legitimate data in his book? Bailey's response to this is a resounding no- that he did not, during the production of his book, see legitimate evidence of transwomen whose lives and histories flew in the face of Blanchard's taxonomy and what he saw as the substantial scientific evidence for it (Bailey, 2006a). Of course, McCloskey, Conway, and others have claimed otherwise. I think this one ends up as a problem that has stumped philosophers of science for ages, namely the problem of how scientists (or scholars more generally) are to discern what data count as legitimate and relevant. Given the 
evidence for Blanchard's theory and the lack of peer-reviewed evidence or argumentation refuting it, Bailey is about as convinced of the theory as he is of the theory of evolution by natural selection - though, when I jokingly asked him, he did say he thinks Blanchard's theory is more likely to eventually fall than Darwin's (p.e.c., January 3, 2007). Bailey considers claims made against Blanchard's theory extraordinary, and extraordinary claims require extraordinary proof. Thus, what seems to some trans critics obvious proof against Blanchard strikes Bailey as very weak indeed (Bailey, 2006a). No matter how many transwomen bombard Bailey with claims of being a "third type" unexplained by Blanchard's theory, I don't think Bailey can be called unethical for sticking stubbornly to a theory he believes to be, all in all, well-evidenced not only in his own experience but in the scientific literature (e.g., Blanchard 1989, 1993; Smith, van Goozen, Kuiper, \& CohenKettenis, 2005).

So in conclusion, what did Bailey do wrong legally, ethically, and morally? It seems J. Michael Bailey should have been more proactive in protecting the identity of Anjelica Kieltyka. It also seems he should perhaps have worked harder to be as clear as humanly possible with Kieltyka just how unlikely she was to ever convince him that Blanchard's theory was wrong, so that she was not at risk of continuing to relate with him under an umbrella of wishful thinking.

That's it? After months of investigation evinced by the foregoing, I must conclude: that's it.

How could there possibly have been so much smoke and so little fire? One answer is that, if you look as closely as I have done here, there were in fact far fewer accusers of Bailey than all the noise in the press and on the Internet would have you believe. And of the accusations made, almost none appear to have been legitimate. But all of the noise of the accusations did what I suspect Conway, James, and McCloskey hoped: It distracted attention from the book's message - that Blanchard's theory of MTF transsexualism was right-by apparently killing the messenger. Indeed, much as Bailey would prefer not to admit it, in their leadership of the backlash against $T M W W B Q$, Lynn Conway, Andrea James, and Deirdre McCloskey came remarkably close to effectively destroying J. Michael Bailey's reputation and life.

\section{Part 6: Epilogue}

So what happened to the text at the center of all this? I asked Stephen Mautner, a representative of the publisher, Joseph Henry Press, how many copies of $T M W W B Q$ were ultimately sold. Mautner first sought Bailey's permission to answer my question-sales figures are ordinarily privileged information-and then, given the go-ahead, Mautner revealed that as of August 2006, the book had sold about 4200 copies. That would be considered a moderate number for an academic book and a low number for a trade book, which $T M W W B Q$ was intended to be. But, Mautner continued, "The big story is the activity online," where Joseph Henry's books were until recently available to anyone to read for free. "Since publication, there have been about 900,000 visits to the electronic version of $[T M W W B Q]$. We are not able to tell you how many of those were repeat visits, but by any measure, that's a LOT of online reading" (Stephen Mautner to Michael Bailey, copy to Alice Dreger, p.e.c., August 11, 2006; capitalization in original).

Given that the book probably turned out to have at least a quarter-million readers (and possibly many more), did $T M W W B Q$ ultimately have the negative effect on transwomen that so many of Bailey's trans critics feared at the outset? I think that is hard to demonstrate. In their January, 2004 letter to the faculty of Northwestern University's Department of Psychology, denouncing Bailey "as a central figure in an elite reactionary group [... in] pursuit of institutionalized bigotry and defamation of transsexual women," Anjelica Kieltyka, Lynn Conway, Andrea James, and Calpernia Addams claimed of knowing "how Bailey's junk science is hurting young trans women." They said they were aware "of cases where it is destroying [young transwomen's] relationships with families and friends, limiting or even ruining their chances for employment, and causing deep emotional angst." They named one specific instance: "One woman wrote to us describing how her mother came running into her bedroom after reading Bailey's book, and threw the book at her shouting, 'Now I know what you are!'” (letter from Kieltyka, Conway, James, and Addams, to the faculty members of the Department of Psychology, Northwestern University, January 7, 2004).

Nevertheless, I have found it impossible to locate any independent confirmation that $T M W W B Q$ has been responsible for these kinds of negative effects-employment discrimination, ruining of relationships, and "deep emotional angst" - although it seems reasonable to presume that those who read it may have come away believing Blanchard's taxonomy more than the feminine essence narrative, and that that will have caused certain transwomen real angst. Bailey has certainly received copious correspondence from transwomen claiming to be a "third type" not addressed in Blanchard's theorizing or Bailey's book_-just as Bailey has received substantial correspondence from transwomen who thank him for explaining Blanchard's theory and thus helping them to make sense of their lives as "homosexual transsexuals" and "autogynephilic transsexuals" (J. Michael Bailey, personal files; compare http://www.transkids.us.). When I wondered to Anne Lawrence whether it might be true that $T M W W B Q$ has led to transwomen suffering things such as employment discrimination, ostracism, deep angst, or even-as Kieltyka, Conway, James, and Addams implied in their January, 2004 letter to Bailey's closest colleagues_-violent hate crimes, Lawrence responded: "At the risk of stating the obvious, the 
reason that Conway, James, McCloskey, [Becky] Allison, [Christine] Burns, et al. are so angry is not because they are so sure that Bailey is wrong. It is because they worry that he might be at least partly right and this realization is potentially fatal for their hard-earned sense-of-self" (p.e.c., December 11, 2006; italics added). In that vein, Lawrence agrees with the claim about angst, but thinks it is not an unjust angst thrust upon particularly vulnerable young transwomen. Bailey is more blunt in his assessment: he says that if there has been an injury from his book-a book he sees as positive in its honesty and in its acceptance of transwomen's realities-it has been a narcissistic injury suffered by a small number of autogynephilic transsexuals who wish we would all deny the truth (Bailey to Dreger, p.e.c., February 27, 2007).

Several people have claimed $T M W W B Q$ and the ensuing controversy have had substantial negative effects on sex researchers' relationships with transwomen, because supposedly they have made the two groups deeply suspicious of each other. In his review of the book, University of Minnesota sex researcher Walter Bockting argued that the controversy constituted "yet another blow to the delicate relationship between clinicians, scholars, and the transgender community," a real problem for the professionals (like him) in question, since clinicians and researchers "cannot do this work without the cooperation and support of the transgender community" (Bockting, 2005). Recall that, similarly, Bockting's University of Minnesota colleague Eli Coleman has publicly argued that $T M W W B Q$ equated to "an unfortunate setback in feelings of trust between the transgender community and sex researchers" (Eli Coleman, p.e.c., August 4, 2006). Meanwhile, trans advocate Jamison Green reported to me that "A few sex researchers that I know have expressed dismay over the controversy, [but] mostly to say that they were sorry that Bailey treated both his subjects and the topic in such a cavalier manner" (Jamison Green, p.e.c., August 20, 2006).

Nevertheless, a number of sex researchers with whom I talked made the argument that, while Bailey's book perhaps rubbed some people the wrong way-and perhaps rubbed them the wrong way more than it needed to do to make its points-it was the over-the-top response from Conway and her colleagues that really put a chill on sex researchers' interest in trans issues. Steven Pinker of Harvard University opined to me, "The intimidation directed at Bailey will ensure that graduate students, post-docs, and other young researchers will not touch this topic with a ten-foot pole, starving the field of new talent. Only tenured professors who have decided to change fields-a tiny number-would take it on" (p.e.c., June 27, 2006). Blanchard had a similar take:

The population of people who were actively doing research on transgender was already pretty small[....] If anything, [the attack on Bailey] has had a discouraging effect about getting into the area of study. It's not hard for a student to see, if they have a choice of topics, "Why should I pick one where the subjects are likely to get litigious or make a fuss, or suspect everything I do?" (Blanchard, 2006)

Blanchard was striking a common chord here; many sex researchers told me-without wishing to be named - that trans activists such as James have behaved so crazily, the entire population they "represent" has been marked by researchers as being too unstable and dangerous to bother with.

Beyond the research realm, what about the effect $T M W W B Q$ has had on clinicians and their trans clients? Again, most people I talked with seem to think its effects have been small or negligible. Although, as we have seen, Bockting (2005) thought the book would harm clinician-client relationships, Jamison Green has speculated that it has had little effect: "I've not seen [the book] cited in any important articles or books, other than to comment on the controversy it generated[....] Most of the clinicians that I've spoken to don't seem to be aware of the book or the controversy" (p.e.c., August 20, 2006). It certainly does seem to be the case that Bailey's book and Blanchard's theory continue to be largely ignored in the popularized gender psychology literature, literature that generally accepts and promotes the feminine essence narrative as the one and only true story of MTF transsexualism.

What about the book's and controversy's effects on trans advocacy? Several people have argued for a generally positive outcome there. So Simon LeVay suggested to me,

It may be that [the criticisms and attacks] have raised the visibility of transgendered people to some extent. For example, I like the fact that Ben Barres of Stanford has become quite vocal in the area of sexuality and gender, even though I don't agree with everything he says. I think Mike's book sparked that to some extent. (p.e.c., August 2, 2006)

Jamison Green similarly argues that "I think the Conway-led response had a positive effect on the community at large. I believe people felt empowered by it, because it modeled a powerful self-regard and courage to stand up for what one believes in, which is something that trans people need to see and internalize" (p.e.c., August 20, 2006). But others believe that the nastiness that ensued from the controversy shut down productive discussion of the etiology and meaning of MTF transsexualism among transwomen and indeed among sex researchers to some extent. When I asked Anne Lawrence about the effects of the book and the controversy, she told me that

extreme reactions led to a hardening of positions. It became difficult for anyone to stake out a middle ground 
concerning the book [and its claims]. It became hard to say, "Well, some things could have been expressed more sensitively or with more qualification, but there is still great value in the book." And because the attacks on Bailey have been so unfair, those of us who find value in the book and who like and respect Bailey are not inclined to talk about what we might wish he had done differently. It's almost impossible now to stand in the middle. (Lawrence, 2006a)

As Lawrence was hinting here, a few people have suggested that Bailey might have avoided at least some of the fray if he had only been more politic in some of his wording. LeVay told me that, when he saw the manuscript of the book, he encouraged Bailey to be careful that his terminology not cause him to "be read as blurring or denying the real differences that exist between gay and transgendered people, especially in the area of self-identification." He went on, "I don't think that Mike made any significant changes as a result of that comment of mine, which was perhaps unfortunate because [it] did in fact spark some (unnecessary) hostile reactions" (p.e.c., August 2, 2006). But I suspect Bailey was right when he told me that he was going to encounter resistance to his support of Blanchard's taxonomy regardless of how he phrased it. Blanchard is sure: "If Mike's book had been written by someone who [had] self-censored every paragraph, Conway et al. would not have liked the message any better. They would not have liked the bottom line message" (Blanchard, 2006).

For his part, Bailey says he doesn't care primarily about whether the book had a negative or positive effect; he cares that he told what he saw as the truth, and that he continued to speak what he saw as the truth in the face of vitriolic personal assaults. He clearly puts the value of truth-seeking and truthtelling over the value of the complicated relationships among sex researchers, gender clinicians, and trans people-complicated (even tangled) relationships he sees as having perpetuated the universalizing of the feminine essence narrative at the exclusion of reality. He argues that speaking the truth will help trans people more in the long run, even if it hurts in the short run:

It is almost always better (in terms of having a positive effect) to know and speak the truth than it is to believe and speak something that is untrue, even if the former upsets people more than the latter. Furthermore, I have profound skepticism regarding claims that $\mathrm{X}$ should not be studied or said because it is dangerous, harmful, or hurtful to do so. (p.e.c., January 29, 2007)

So was Bailey speaking the truth-not just the truth as he knew it, but the truth? It is beyond the scope of this history to examine the evidence for and against Blanchard's typology of MTF transsexualism. I will say here that the literature around Blanchard's theory looks ripe for a thorough queer theory- based, science studies critique that would consider the possible inconsistencies, blind spots, and culture-heavy assumptions in that literature. A number of reasonable questions could (and should) be raised: What do we make of the varied ways that autogynephilia has been conceived, including by Blanchard himself (Blanchard, 2005)? What of the choice of terms used, and how might those terms constrict conceptions of the phenomena and harm (or help) the individuals in question? Could "autogynephilia" exist in at least some natal women, and if so, might autogynephilia in MTFs not be understood as a sign of a core female gender identity? Patterns of demographic differences between "homosexual transsexuals" and "autogynephilic transsexuals" are taken as evidence for Blanchard's theory (see, e.g., Smith et al., 2005), but to what extent might those apparent demographic differences be a product not of inherent differences in those people but in the way androphilic MTFs versus non-androphilic MTFs are treated in our culture?

Pending a thorough critical analysis of Blanchard's theory, let me say for this historical record, reports of its death have been premature. Blanchard's explanatory typology certainly has not been roundly rejected by virtually all sexologists, as the sites of people such as Conway and James suggest. Although fewer sexologists are as familiar with it as Blanchard and Bailey would like, there are indeed researchers considering its explanatory power and evidentiary basis - and some have found evidence to support it. For example, a group in the Netherlands found that

Homosexual transsexuals were [...] younger when applying for sex reassignment, reported a stronger crossgender identity in childhood, had a more convincing cross-gender appearance [....] Moreover, a lower percentage of the homosexual transsexuals reported being (or having been) married and sexually aroused while cross-dressing.

These researchers concluded, "A distinction between subtypes of transsexuals on the basis of sexual orientation seems theoretically and clinically meaningful" (Smith et al., 2005; see also Chivers \& Bailey, 2000). And while Blanchard's work on MTF transsexualism has been portrayed by his critics as if it was merely theoretical with no real empirical basis, the truth is that Blanchard himself has also sought and published empirical data for his typology and his theory of autogynephilia (see, e.g., Blanchard, 1992). For instance, he has demonstrated a high prevalence of sexual arousal to cross-gender fantasy among non-homosexual MTF transsexuals (Blanchard, 1989) as well as showing that "nonhomosexual men most aroused sexually by the thought of having a woman's body are also those most interested in acquiring a woman's body through some permanent, physical transformation" (Blanchard, 1993). 
What of the supposed evidence against Blanchard's theory? Many transwomen have complained that, in their work, Blanchard and Bailey have ignored their life narratives, narratives that these women say fly in the face of the simple twotype model of MTF transsexualism that sees eroticism as a fundamental motivation for MTF sex reassignment. But what many of these critics have failed to realize is that Bailey and Blanchard aren't interested in whether people's narratives fit Blanchard's theory; they are interested in whether people do. And Bailey and Blanchard see plenty of evidence that, selfrepresentation to the contrary, transwomen's historiesincluding their gendered and erotic histories - and the data drawn from them in lab-based and clinical studies support rather than weaken Blanchard's typology.

There have been multiple attempts to shut down meaningful public discussion of Blanchard's theory, even beyond the controversy that surrounded $T M W W B Q$. So the Wikipedia entries on "homosexual transsexual," "autogynephilia," and "Blanchard, Bailey, and Lawrence theory" seem to be permanent sites of dispute, with editors constantly replacing, spinning, deleting, and augmenting each other's contributions. But there remain resilient pockets not only of sexologists who subscribe to Blanchard's theoretical work, but also of transwomen who subscribe to it and identify themselves as "homosexual transsexuals" and "autogynephilic transsexuals" (though not always without questioning Blanchard's choice of terminology). For example, as noted in Part 4, the "Transkids" Website records the autobiographies and critiques of transwomen who see themselves as fitting the "homosexual transsexual" model (http://www.transkids.us). For a time, during the height of the Bailey controversy, there was also an active listserv of self-identified autogynephilic transwomen, and even today, after the $T M W W B Q$ blow-up, a small number of transwomen such as Willow Arune and Anne Lawrence continue to be open about their self-identification as autogynephilic transwomen (Arune, 2004; Lawrence, 2007; see also the "narratives about autogynephilia" at Lawrence, 1999a, 1999b).

Indeed, even people highly critical of Bailey sometimes acknowledge the existence of autogynephilia, though they discount its importance in trans identity and deny Blanchard's two-type taxonomy. Thus, Bockting told me, "Autogynephilia is not an uncommon phenomenon among my clients, and a phenomenon that is relevant and part of their identity development. However, I do not see it as an identity in and of itself" (p.e.c., August 30, 2006). Others acknowledge the phenomenon of erotic crossdressing but refuse to categorize it as "autogynephilia"; so transwoman Becky Allison, M.D., asks rhetorically in her critique of Bailey's book, “am I suggesting that eroticism while crossdressing played no part in my history, or in the histories of my many non-autogynephilic friends? I am not. It did play a part. A small part. Call it a phase if you will" (Allison, 2003). So I think it is fair to say that the role of eroticism-including erotic crossdressing - in transsexualism remains a lively point of discussion, as does Blanchard's two-part typology.

The controversy over Bailey's book has allowed his critics to lump together the work of Bailey, Blanchard, and Anne Lawrence as a monolithic, containable, anti-trans-rights theoretic entity known as "the Blanchard, Bailey, Lawrence theory" (see, e.g., James, n.d.-h). But this strikes me as a blatant mischaracterization at several levels. First, in a move I think could only be labeled pro-trans-rights, Blanchard, Bailey, and Lawrence have each actively argued that the chief determinant of whether transwomen should have access to SRS is whether or not individual transwomen are better off (Bailey, 2003; Blanchard, 2000; Lawrence, 2003). Blanchard and Lawrence have done the work to show that they generally are better off (Blanchard, 1985, 2000; Blanchard, Clemmensen, \& Steiner, 1983; Blanchard, Legault, \& Lindsay, 1987; Blanchard \& Sheridan, 1990; Blanchard \& Steiner, 1983; Blanchard, Steiner, \& Clemmensen, 1985; Blanchard, Steiner, Clemmensen, \& Dickey, 1989; Lawrence, 2003). This is the work that Bailey alludes to in his book when he writes about why Paul McHugh is wrong to deny transwomen access to reassignment (Bailey, 2003, p. 207). Second, referring to the theory as the "Blanchard-Bailey-Lawrence" theory conveniently denies that there are plenty of other professional sexologists who take seriously Blanchard's typology of homosexual and nonhomosexual MTF transsexuals (see, e.g., Cohen-Kettenis \& Gooren, 1999; Green, 2000; Kelly, 2005; LeVay \& Valente, 2006; Schroder \& Carroll, 1999; Smith et al., 2005; van Goozen, Slabbekoorn, Gooren, Sanders, \& Cohen-Kettenis, 2002). Third, the "Blanchard-Bailey-Lawrence" construction fails to give Blanchard the substantial priority he is due.

Finally, it seems to me that there are actually subtle but key differences in the way that Blanchard and Bailey have conceived of and Lawrence is now conceiving of autogynephilia. Lawrence is developing a conceptualization of autogynephilia as a real sexual orientation, akin to the way being homosexual or heterosexual is a sexual orientation. Like Blanchard and Bailey, she sees autogynephilia as a paraphilia, but she seems to be more interested than Blanchard and Bailey in elaborating what it means to take seriously autogynephilia as a sexual orientation. So she has been theorizing the roles of the eroticbased, attraction-based, and attachment-based elements of autogynephilia, and considering how the balance of these elements might change as an autogynephilic transsexual develops her identity as woman. When she speaks of autogynephilia, Lawrence speaks much more of "becoming what we love" than "becoming what we lust after". All this, she suggests, helps to explain why some transwomen who admit to erotic crossdressing pre-transition say that they essentially give up or lose what looks like autogynephilia after transition, especially after the reduction of libido that happens with 
the intentional shift from male-typical to female-typical hormones. Thus, what some transwomen label as "an autogynephilic stage" in personal development is understood by Lawrence as representing a period when the erotic component of autogynephilia is more prominent (and undeniable) than it becomes later in the lives of most autogynephilic transsexuals. Consequently, in spite of being lumped into what gets labeled by its critics the "Blanchard-Bailey-Lawrence" theoretical construct, Lawrence seems to be developing a vision of autogynephilia that is more complex and potentially more explanatorily powerful (and possibly even more palatable) than what has thus far been put forward (Lawrence, 2004, 2006b, 2007).

But will Blanchard's theory ever make it into the mainstream of trans politics and discourse? To do so, it would have to overcome the widespread political rejection of a model that sees transsexuality as a pathology. After all, Blanchard, Bailey, and Lawrence have all argued that autogynephilia is a paraphilia-a psychosexual disorder. Granted, they argue autogynephilia is a non-harmful paraphilia, and one which absolutely should not eliminate a transwoman from consideration for sex reassignment. But as long as they talk of any kind of transsexuality as a paraphilia, I think it is unlikely Blanchard's theory will find anything like general acceptance among politically conscious trans people who, understandably, are sick and tired of being treated as if they suffer from a pathology.

Putting aside for a moment the whole problem of the scientific truth about MTF transsexuality, I'm not sure that the simplistic feminine essence narrative is necessarily any better for transwomen than Blanchard's typology. In doing research for this project, I have been disturbed to see the extent to which transwomen, in order to speak and be heard, seem to feel obliged to completely deny the role of eroticism in their decisions to undergo sex reassignment — and not just by trans activists like Conway and James, but also by gender therapists like Randi Ettner and Mildred Brown, and by the press. Historically, this de-eroticization of transsexuals' life narratives has been promoted not only by certain transwomen like Christine Jorgensen but also, importantly, by the medical professionals who have acted as gatekeepers to sex reassignment (Meyerowitz, 2002). After all, in the past, some influential clinicians claimed that confession of a single instance of sexual arousal associated with crossdressing should eliminate a patient from consideration of a diagnosis of transsexualism and thus also from consideration of sex reassignment (see, e.g., Baker, 1969). Although the de-eroticized feminine essence narrative may function socially and clinically like a sort of get-out-of-male-free card, this pushing of sex into the closet where transsexuality is concerned at some level robs transwomen of their erotic possibilities and realities, and in that sense Ettner and Brown are surely doing their clients and readers no favors. I personally hope that as trans activists seek to work for greater acceptance of trans people, they also do not insist upon a complete and universal de-eroticization of trans people's life histories.

Importantly, as Lawrence has pointed out, there exists an almost invisible group of people for whom the universalizing of the feminine essence narrative may (ironically) act as a barrier to beneficial sex changes. These are male-bodied people who experience severe, sometimes incapacitating distress about or alienation from their male bodies but who do not feel in themselves a "feminine essence" others seem to be describing. If a "feminine essence" feeling is said to be the necessary motivation for a sex change, these people may not seek and get sex changes from which they would truly benefit (Lawrence to Dreger, p.e.c., March 23, 2007). This constitutes another reason why the feminine essence narrative-especially at the exclusion of all other possibilities - may harm some trans people even as it seems to help others.

Ironically, as some science studies scholars have suggested, it is gender clinicians and sexologists themselves who have set the scene for trans women denying anything other than feminine essence autobiographies by demanding singular sorts of Western heteronormative stories out of MTFs seeking SRS (Stone, 1991; see also Meyerowitz, 2002). Clinicians like Robert Stoller maintained a dichotomy of "true transsexuals" (i.e., androphilic would-be MTFs who came with what looked like feminine essence narratives) versus "transvestites" (including non-androphilic would-be MTFs who confessed to erotic cross-dressing), insisting only the former sort be allowed SRS (Stoller, 1971). Although Blanchard and most of his followers have abandoned this language of "true" versus untrue transsexuals, and have insisted (and even shown) that SRS can benefit "autogynephilic" transsexuals as much as "homosexual" transsexuals, the legacy of their more prohibitive predecessors hangs over the clinical and political representations of MTF transsexuality.

Finally, what of the individuals who played major parts in the history of the controversy over $T M W W B Q$ ? As I write, Deirdre McCloskey maintains an active and prominent academic career, enjoying an international reputation as an interdisciplinary scholar. Lynn Conway, now retired from the University of Michigan, continues to use her university Website to broadcast her ongoing "investigation" of Bailey and to provide inspiring stories of successful transwomen like herself. Andrea James keeps up her own Website as a source of consumer advice to transwomen, as a marketing platform for herself, and as a font of intimidation to those who would dare to openly disagree with her. James was featured on the front cover of The Advocate's June 2006 Pride Special; inside she was quoted as saying, "I consider myself agnostic but guided by a set of unwavering moral principles" (James, 2006). I do not know what has happened to the woman known as Juanita.

As for Anjelica Kieltyka, my sense is that she feels chewed up and spat out several times over. It is clear she now feels she 
was being used by Bailey all along, and I take from what she told me that she also feels abused by Conway and her "coinvestigators." During our interviews, she remembered several times that the last thing Michael Bailey ever said to her was to warn her of Conway and James, "Don't let them use you" (Kieltyka, 2006c, 2006d). Of all the people in this story, Kieltyka is the one I worry about. She struck me-both in her biography and in our conversations - as a genuinely kindhearted person who truly tried to help her fellow transwomen along the way, only to find herself ejected from that community. She told me, "The problem is that Conway [came] in and befriended all of my friends and turned a number of them into discrediting me" (Kieltyka, 2006f). She can't even seem to attend the regular trans gatherings she used to without risking being misunderstood and rejected. Just as I told her of Conway's bizarre threat to tell people I was stalking her, Kieltyka recalled to me, with some anger,

the recent incident at the Be-All [a trans gathering] where [Conway] accused me of stalking her. I was at the bar over there and she was among my friends and I [...] heard that she was going around saying that I was stalking her. [...] Anyway, it was a nonevent that Professor Conway tried to turn into a "staged event" —an opportunity to discredit me. (Kieltyka, 2006a)

A woman who once enjoyed an active life among the transwomen circles of Chicago, a woman who once valued her regular association with academics (including Bailey and his colleagues) at Northwestern University, Kieltyka has now become largely isolated through what she feels has been one misrepresentation of her after another.

Meanwhile, on the sex research side, Blanchard says he hasn't been much affected personally by the controversy, because "there were no opportunities for those people to attack me the way they had attacked Mike." Blanchard had already lost interest in doing work in transsexuality before $T M W W B Q$, and, not surprisingly, the controversy has not rekindled his interest. He did tell me he found the backlash

discouraging. I guess to some extent I'm used to academic controversies, and however vicious those get, people have a common understanding of where you draw the line about disputing a theory or an idea. In this particular battle, people were not playing by the familiar academic rules. James put up pictures of Mike's children, people moved to have books removed from consideration for awards. This was totally out of the rules of discourse. (Blanchard, 2006)

When I asked Lawrence about how she had been affected by the backlash personally_a backlash that ended up repainting her as a sworn enemy of trans rights-Lawrence said:
It feels like a great loss to be so alienated from my own community. I have worked very hard on behalf of my community. For over 10 years now, I have tried to provide accurate information for MTF transsexuals on my website. And I worked so hard to try to liberalize the [HBIGDA] Standards of Care! [Sex researcher and FTM] Aaron Devor and I must have put in close to a hundred hours, trying to make Version Six [of the Standards of Care] better for transpeople and reduce barriers to care. I conducted the research that demonstrated, among other things, that nonhomosexual transsexuals can have outcomes from sex reassignment surgery that are every bit as good as those of homosexual transsexuals. I used to be respected, even admired, within my community. Now many people see me as the anti-Christ. I rarely attend transgender conventions anymore. (Lawrence, 2006a)

And Bailey? Undaunted, he plugs ahead, working on more sexual-orientation studies_-studies likely to keep angering people on both the right and the left who wish his work fell simply into one of the politicized scientific boxes on which they insist. He is relieved that, with the dust of the backlash settling and the full history emerging, his colleagues seem increasingly inclined to rally to his side and to the sides of similarly beleaguered sex researchers (see, e.g., De Vries et al., 2007).

As I was nearing the end of my research into this history, I asked Bailey whether he regrets publishing his book. Not a bit, he replied. Regrets the backlash? At this, he surprised me by answering, "I have decided that I'm glad for everything, even Lynn Conway's behavior." The backlash, he explained to me, made him realize what fine family, friends, and colleagues he has, to stand by him for all the right reasons. On top of that, he notes, the backlash also did exactly what I had warned Conway back in 2003 it would: it gave his book far more publicity than it otherwise would have had. And finally, Bailey explained, the whole experience "has taught me, albeit the hard way, the value of truth." He went on, "I think that before, sometimes, I used to hesitate to say true things out of concern that the truth would cause someone pain. But Conway et al. took away any remaining inhibitions I had against telling the truth" (p.e.c., January 30, 2007).

Acknowledgments My thanks go to the more than 100 people who answered inquiries on this project, Yorgos Strangas for excellent research assistance, the Editor for patient editorial assistance, and the following people for comments on drafts of this article: Marcus Arana (Holy Old Man Bull), William B. Kelley, Lisa Lees, Kathryn Montgomery, James L. Nelson, Maxine Petersen, Julie F. Simpson, Aron Sousa, John Sylla, Kiira Triea, Paul Vasey, 13 readers who asked that I not name them, and three anonymous reviewers. Thanks to Claire Hoipkemier and Kepler Domurat-Sousa for assistance with proofing. 


\section{References}

Allison, B. (2003, April 13). NONs (or the National Academy meets the National Enquirer). Retrieved October 16, 2006, from http:// www.drbecky.com/blog05.html\#apr13

Allyn \& Bacon. (2004). Human sexuality videoworkshop [14 modules on CD-Rom]. Boston: Allyn \& Bacon.

American Association of University Professors. (2006). Research on human subjects: Academic freedom and the Institutional Review Board. Retrieved January 1, 2007, from http://www.aaup.org/ AAUP/About/committees/committee+repts/CommA/Researchon HumanSubjects.htm

Arune, W. (2004). I *am* Arune. Transgender Tapestry, 106, 44-51.

Bad Science. (2006, August 9). Chicago Free Press. Retrieved February 29, 2008, from http://ai.eecs.umich.edu/people/conway/TS/Bailey/ Chicago\%20Free\%20Press/Chicago\%20Free\%20Press\% 20 EDITORIAL\%208-09-06.htm.

Bailey, Deb (2006, August 9). Interview with Alice Dreger; no revisions to transcript.

Bailey, Drew (2006, June 20). Interview with Alice Dreger; revised transcript received August 1, 2006.

Bailey, J. M. (2003). The man who would be queen: The science of gender-bending and transsexualism. Washington, DC: Joseph Henry Press.

Bailey, J. M. (2005, October 9). Academic McCarthyism. Northwestern Chronicle. Retrieved February 19, 2007, from http://www. chron.org/tools/viewart.php?artid=1248

Bailey, J. M. (2006a, July 6). Interview with Alice Dreger; revised transcript received July 18, 2006.

Bailey, J. M. (2006b, August 8). Interview with Alice Dreger; revised transcript received August 8, 2006.

Bailey, J. M. (2006c, August 25). Interview with Alice Dreger; no revisions to transcript.

Bailey, J. M., \& Pillard, R. C. (1991). A genetic study of male sexual orientation. Archives of General Psychiatry, 48, 1089-1096.

Bailey J. M., Pillard, R. C., Neale, M. C., \& Agyei, Y. (1993). Heritable factors influence sexual orientation in women. Archives of General Psychiatry, 50, 217-223.

Baker, H. J. (1969). Transsexualism: Problems in treatment. American Journal of Psychiatry, 125, 1412-1418.

Barlow, E. (1996). Masculine and feminine traits in homosexual transsexuals, homosexual cross-dressers and gay men. Unpublished Honor's thesis, Northwestern University, Evanston, IL.

Barlow, G. (2003, December 17). NU professor faces sexual allegations. Chicago Free Press.

Beatty, C. (2003, Fall). [Review of the book The man who would be queen]. Transgender Tapestry, 103, 27-28, 56.

Becker, R. (2003, July 29). Author is ripped for transsexual research. Chicago Tribune. This appears on p. 1 of the Metro section.

Beirich, H., \& Moser, B. (2003, Winter). Queer science: An 'elite' cadre of scientists and journalists tries to turn back the clock on sex, gender and race. Southern Poverty Law Center Intelligence Report. Retrieved December 10, 2006, from http://www.splcenter.org/intel/ intelreport/article.jsp?sid=96

Blanchard, R. (1985). Gender dysphoria and gender reorientation. In B. W. Steiner (Ed.), Gender dysphoria: Development, research, management (pp. 365-392). New York: Plenum Press.

Blanchard, R. (1989). The concept of autogynephilia and the typology of male gender dysphoria. Journal of Nervous and Mental Disease, 177, 616-623.

Blanchard, R. (1992). Nonmonotonic relation of autogynephilia and heterosexual attraction. Journal of Abnormal Psychology, 101, 271-276.

Blanchard, R. (1993). Varieties of autogynephilia and their relationship to gender dysphoria. Archives of Sexual Behavior, 22, 241-251.
Blanchard, R. (2000, April). Part II: The case for publicly funded transsexual surgery. Psychiatry Rounds, 4(2), 4-6.

Blanchard, R. (2005). Early history of the concept of autogynephilia. Archives of Sexual Behavior, 34, 439-446.

Blanchard, R. (2006, August 2). Interview with Alice Dreger; revised transcript received August 3, 2006.

Blanchard, R., Clemmensen, L. H., \& Steiner, B. W. (1983). Gender reorientation and psychosocial adjustment in male-to-female transsexuals. Archives of Sexual Behavior, 12, 503-509.

Blanchard, R., Legault, S., \& Lindsay, W. R. (1987). Vaginoplasty outcome in male-to-female transsexuals. Journal of Sex and Marital Therapy, 13, 265-275.

Blanchard, R., \& Sheridan, P. M. (1990). Gender reorientation and psychosocial adjustment. In R. Blanchard \& B. W. Steiner (Eds.), Clinical management of gender identity disorders in children and adults (pp. 159-189). Washington, DC: American Psychiatric Press.

Blanchard, R., \& Steiner, B. W. (1983). Gender reorientation, psychological adjustment, and involvement with female partners in female-to-male transsexuals. Archives of Sexual Behavior, 12, 149-157.

Blanchard, R., Steiner, B. W., \& Clemmensen, L. H. (1985). Gender dysphoria, gender reorientation, and the clinical management of transsexualism. Journal of Consulting and Clinical Psychology, 53, 295-304.

Blanchard, R., Steiner B. W., Clemmensen L. H., \& Dickey R. (1989). Prediction of regrets in postoperative transsexuals. Canadian Journal of Psychiatry, 34, 43-45.

Boatner, E. (2003). [Review of the book The man who would be queen]. Lavender Magazine. Excerpt retrieved March 28, 2007, from http://www.nap.edu/catalog/10530.html

Bockting, W. O. (2005). Biological reductionism meets gender diversity in human sexuality [Review of the book The man who would be queen]. Journal of Sex Research, 42, 267-270.

Bornstein, K. (1994). Gender outlaw: On men, women, and the rest of us. New York: Vintage.

Brown, M. L., \& Rounsley, C. A. (1996). True selves: Understanding transsexualism. San Francisco: Jossey-Bass.

Byrd, A. D. (2006). [Review of the book Sexual orientation and psychoanalysis: Sexual science and clinical practice]. Retrieved March 22, 2007, from http://www.narth.com/docs/sexualscience. html

Cantor, J. M. (2003). [Review of the book The man who would be queen]. Newsletter of Division 44 of the American Psychological Association, 19(2), 6

Center for Advanced Study. (2005). Improving the system for protecting human subjects: Counteracting IRB "mission creep" (also known as The Illinois White Paper). Retrieved February 27, 2007, from the University of Illinois at Urbana-Champagne Website: http://www.law.uiuc.edu/conferences/whitepaper

Chivers, M. L., \& Bailey J. M. (2000). Sexual orientation of female-tomale transsexuals: A comparison of homosexual and nonhomosexual types. Archives of Sexual Behavior, 29, 259-278.

Chivers, M. L., Rieger, G., Latty, E., \& Bailey, J. M. (2004). A sex difference in the specificity of sexual arousal. Psychological Science, 15, 736-744

Cohen-Kettenis, P. T., \& Gooren, L. J. (1999). Transsexualism: A review of etiology, diagnosis and treatment. Journal of Psychosomatic Research, 46, 315-333.

Conway, L. (Ed.). (2003a). Early reviews and comments on Bailey's book by transwomen and transmen. Retrieved February 21, 2007, from http://ai.eecs.umich.edu/people/conway/TS/BaileyA1.html

Conway, L. (2003b). An investigative report into the publication of $J$. Michael Bailey's book on transsexualism by the National Academies. Retrieved January 22, 2007, from http://ai.eecs.umich.edu/ people/conway/TS/LynnsReviewOfBaileysBook2.html 
Conway, L. (Ed.). (2003c). A second woman files research misconduct complaints against Bailey. Retrieved December 12, 2006, from http:// ai.eecs.umich.edu/people/conway/TS/Bailey/SecondComplaint.html

Conway, L. (Ed.). (2003d). A third woman files research misconduct complaints against Bailey. Retrieved December 12, 2006, from http:// ai.eecs.umich.edu/people/conway/TS/Bailey/ThirdComplaint.html

Conway, L. (Ed.). (2003e). Documentation of a formal complaint about J. Michael Bailey's sexual exploitation of a research subject, and of Northwestern University's apparent decision to not investigate such egregious misconduct. Retrieved December 12, 2006, from http://ai.eecs.umich.edu/people/conway/TS/ Bailey/KeyDocuments/Misconduct-12-11-03.html

Conway, L. (Ed.). (2003f). A fourth trans woman files a formal complaint with the Vice President of [sic] Research of Northwestern University regarding the research conduct of J. Michael Bailey. Retrieved December 12, 2006, from http://ai.eecs.umich.edu/people/conway/ TS/Bailey/FourthWomansComplaint.html

Conway, L. (Ed.). (2003g). The sinking of "the queen": The saga of the maiden voyage of "the queen" and her collision with a great iceberg off the shores of DSM-land. Reflections and historical illustrations by Charlotte Anjelica Kieltyka. Retrieved December 12, 2006, from http://ai.eecs.umich.edu/people/conway/TS/ Sinking/Sinking.html

Conway, L. (Ed.). (2003h). At the IASR conference at the Kinsey Institute, 19 July 2003. Retrieved December 11, 2006, from http://ai.eecs. umich.edu/people/conway/TS/IASRmessage.html

Conway, L. (Ed.). (2003i). [No unifying title; various documents and comments on HBIGDA's role in the controversy.] Retrieved December 11, 2006, from http://ai.eecs.umich.edu/people/conway/ TS/HBIGDA-ALERT-RE-BAILEY.html

Conway, L. (Ed.). (2003j). HBIGDA officers and board of directors begin to respond to Bailey's book. Retrieved December 11, 2006, from http://ai.eecs.umich.edu/people/conway/TS/HBIGDA-Response-1020-03.html

Conway, L. (Ed.). (2003k). Tuesday, November 4, 2003: Blanchard resigns in a huff from HBIGDA! Retrieved December 11, 2006, from http://ai.eecs.umich.edu/people/conway/TS/BaileyAssociates/ BlanchardResigns.html

Conway, L. (Ed.). (20031). It's fiction! Bailey admits to Anjelica Kieltyka that he fabricated the key final scene in his book. Retrieved June 16, 2007, from http://ai.eecs.umich.edu/people/ conway/TS/DannyFabrication.html

Conway, L. (2004a). The Bailey investigation: How it all began with a series of e-mail alerts. Retrieved January 22, 2007, from http://ai.eecs.umich.edu/people/conway/TS/Bailey/Investigation $\% 20$ start-up/Investigation $\% 20$ start-up.htm

Conway, L. (2004b). Interim investigation report on J. Michael Bailey's 06-02-03 public lecture at UCLA. Retrieved December 10, 2006, from http://ai.eecs.umich.edu/people/conway/TS/ Anjelica/Bailey-UCLA-Lecture.html

Conway, L. (2004c). May 10, 2004: The "May 10th complaint"; a new, confidential formal complaint of research misconduct is filed against J. Michael Bailey at Northwestern University. Retrieved December 11, 2006, from http://ai.eecs.umich.edu/people/ conway/TS/Bailey/May\%2010/The\%20May\%2010,\%202004\% 20Complaint.htm

Conway, L. (Ed.). (2004d). April 6, 2004: Evidence and complaints filed against J. Michael Bailey for practicing as a clinical psychologist without a license, and then subsequently publishing confidential clinical case-history information without permissions. Retrieved December 11, 2006, from http://ai.eecs.umich. edu/people/conway/TS/Bailey/Clinical/ClinicalComplaint.html

Conway, L. (Ed.). (2005a). The gay and lesbian "Lambda Literary Foundation" disses all transsexual women by nominating Bailey's book for a GLB 'T' literary award! Retrieved December 5, 2006, from
http://ai.eecs.umich.edu/people/conway/TS/Bailey/Lambda\%20 Literary\%20Foundation.html

Conway, L. (Ed.). (2005b). April 30, 2005: Dr. Eli Coleman rebukes J. Michael Bailey's book at IFGE 2005. Retrieved December 18, 2006, from http://ai.eecs.umich.edu/people/conway/TS/Trans\% 20Health/IFGE\%202005/Eli\%20Coleman\%20Rebukes\%20 Bailey's\%20Book\%20at\%20IFGE\%202005.htm

Conway, L. (2006a). Timeline of the unfolding events in the Bailey investigation (update of 12-31-06). Retrieved January 22, 2007, from http://ai.eecs.umich.edu/people/conway/TS/Bailey/Time line/Timeline\%20spreadsheet.htm

Conway, L. (Ed.). (2006b). How colleges and universities can improve their environments for TG/TS students (cont.). Retrieved January 22, 2007, from http://ai.eecs.umich.edu/people/conway/TS/ College-Appendix.html

Copaken, D. (Producer). (1993). Sugar and spice. Dateline NBC [Television broadcast]. New York: National Broadcasting Company.

De Vries, G. J., Arnold, A. P., Ball, G. F., Balthazart, J., Baum, M. J., Forger, N. G., et al. (2007, January 30). The gay sheep and sound science [Letter to the editor]. New York Times.

Derbyshire, J. (2003, June 30). Lost in the male [Review of the book The man who would be queen]. National Review, 51-52.

Dreger, A. D. (1998). "Ambiguous sex"—or ambivalent medicine? Ethical problems in the treatment of intersexuality. The Hastings Center Report, 28(3), 24-35.

Dreger, A. D. (2004). Cultural history and social activism: Scholarship, identities, and the intersex rights movement. In F. Huisman \& J. H. Warner (Eds.), Locating medical history: The stories and their meanings (pp. 390-409). Baltimore: Johns Hopkins University Press.

Dreger, A. D. (2006, May 13). The blog I write in fear. Retrieved May 1, 2007, from http://www.alicedreger.com/in_fear.html

Dreger, A. D., \& Herndon, A. (in press). Progress and politics in the intersex rights movement: Feminist theory in action. GLQ: A Journal of Lesbian and Gay Studies.

Ettner, R. (1996). Confessions of a gender defender: A psychologist's reflections on life among the transgendered. Chicago: Chicago Spectrum Press.

Ettner, R. (1999). Gender loving care: A guide to counseling gendervariant clients. New York: W. W. Norton.

France, D. (2000, May 28). An inconvenient woman. The New York Times Magazine, 24-30.

Freund, K., \& Blanchard, R. (1993). Erotic target location errors in male gender dysphorics, paedophiles, and fetishists. British Journal of Psychiatry, 162, 558-563.

Gibson, M. (1999, February 24). True selves. The Daily Northwestern ("Focus" section), p. 1, 5.

Green, J. (2003). Bailey's wick. Retrieved July 18, 2006, from Planet Out Website: http://www.planetout.com/people/columns/green/ archive/20031014.html

Green, R. (2000). Birth order and ratio of brothers to sisters in transsexuals. Psychological Medicine, 30, 789-795.

Greenberg, A. S., \& Bailey, J. M. (2001). Parental selection of children's sexual orientation. Archives of Sexual Behavior, 3, 423-437.

Hiltzik, M. A. (2000, November 19). Through the gender labyrinth: How a bright boy with a penchant for tinkering grew up to be one of the top women in her high-tech field. Los Angeles Times Sunday Magazine.

Hinkle, C. (Ed.). (2006). Alice Dreger: Disorders of sex development. Retrieved October 5, 2006, from http://www.oii-usa.blogspot. com/2006/09/alice-dreger-disorders-of-sex.html

James, A. (n.d.-a). J. Michael Bailey Connections. Retrieved November 12, 2006, from http://www.tsroadmap.com/info/bailey-chart.html).

James, A. (n.d.-b). Simon LeVay on transsexualism. Retrieved June 15, 2007, from http://www.tsroadmap.com/info/simon-levay.html 
James, A. (n.d.-c). Steven Pinker on transsexualism. Retrieved December 11, 2006, from http://www.tsroadmap.com/info/ steven-pinker.html

James, A. (n.d.-d). Internet fakes: "transkids.us." Retrieved February 28, 2007, from http://www.tsroadmap.com/info/transkids/index.html

James, A. (n.d.-e). Jim Marks and J. Michael Bailey. Retrieved December 5, 2006, from http://www.tsroadmap.com/info/jimmarks.html

James, A. (n.d.-f). A note regarding Bailey's children. Retrieved December 7, 2006, from http://www.tsroadmap.com/info/baileychildren.html

James, A. (n.d.-g). Standards of care for women in transition. Retrieved January 22, 2007, from http://www.tsroadmap.com/ reality/hbigda-standards.html

James, A. (n.d.-h). Categorically wrong? A Bailey-Blanchard-Lawrence clearinghouse. Retrieved January 30, 2007, from http://www.tsroadmap.com/info/bailey-blanchard-lawrence.html

James, A. (2003a). Invective against J. Michael Bailey's "The Man Who Would Be Queen." Originally published as a page of http:// www.tsroadmap.com in May 2003 and subsequently removed. Complete copy obtained from the files of J. Michael Bailey. Slightly edited version available at http://web.archive.org/web/2003 0605112712/www.tsroadmap.com/info/j-michael-bailey.html

James, A. (2003b). Joseph Henry Press cites Duncan Osborne. Retrieved February 27, 2007, from http://www.tsroadmap.com/ info/duncan-osborne.html

James, A. (2003c). Joan Linsenmeier on transsexualism. Retrieved December 18, 2006, from http://www.tsroadmap.com/info/ joan-linsenmeier.html

James, A. (2006, June 20). Andrea James. The Advocate, 965, 88.

Kelly, G. F. (2005). Sexuality today (8th ed.). New York: McGrawHill.

Kieltyka, C. A. (Producer/Director). (1999). Becoming real: Chuck to Anjelica [Videotape]. Provided to the author from the personal files of Charlotte Anjelica Kieltyka.

Kieltyka, C. A. (2003a). Images of "Juanita." Originally published at http://www.ai.eecs.umich.edu/people/conway/TS/Juanita.html. Retrieved January 22, 2007, from http://web.archive.org/web/ 20030627161412/http://ai.eecs.umich.edu/people/conway/TS/ Juanita.html

Kieltyka, C. A. (2003b). Anjelica Kieltyka files. [Texts of three formal complaints to Northwestern University]. Retrieved December 12, 2006, from http://ai.eecs.umich.edu/people/conway/TS/Anjelica/ Complaint.html

Kieltyka, C. A. (2006a, August 16). Interview with Alice Dreger; revised transcript received September 22, 2006.

Kieltyka, C. A. (2006b, August 17). Interview with Alice Dreger; revised transcript received September 22, 2006.

Kieltyka, C. A. (2006c, August 21). Interview with Alice Dreger; revised transcript received September 27, 2006.

Kieltyka, C. A. (2006d, August 22). Interview with Alice Dreger; revised transcript received September 27, 2006.

Kieltyka, C. A. (2006e, August 31). Interview with Alice Dreger; revised transcript received September 27, 2006.

Kieltyka, C. A. (2006f, September 19). Interview with Alice Dreger; revised transcript received September 22, 2006.

Kirkus Reviews. (2003). [Review of the book The man who would be queen]. Kirkus Reviews, 71(2).

Lawrence, A. A. (1998). Men trapped in men's bodies: An introduction to the concept of autogynephilia. Transgender Tapestry, 1(85), 65-68.

Lawrence, A. (1999a). 28 narratives about autogynephilia. Retrieved March 25, 2007, from http://www.annelawrence.com/agnarratives. html

Lawrence, A. (1999b). 31 new narratives about autogynephilia, plus five revealing fantasy narratives. Retrieved March 25, 2007, from http://www.annelawrence.com/31narratives.html
Lawrence, A. A. (2003). Factors associated with satisfaction or regret following male-to-female sex reassignment surgery. Archives of Sexual Behavior, 32, 299-315.

Lawrence, A. A. (2004). Autogynephilia: A paraphilic model of gender identity disorder. Journal of Gay and Lesbian Psychotherapy, 8(1/2), 69-87.

Lawrence, A. A. (2006a, August 8). Interview with Alice Dreger; revised transcript received August 17, 2006.

Lawrence, A. A. (2006b). Clinical and theoretical parallels between desire for limb amputation and gender identity disorder. Archives of Sexual Behavior, 35, 263-278.

Lawrence, A. A. (2007). Becoming what we love: Autogynephilic transsexualism conceptualized as an expression of romantic love. Perspectives in Biology and Medicine, 50, 506-520.

LeVay, S., \& Valente, S. M. (2006). Human sexuality (2nd ed.). Sunderland, MA: Sinauer Associates, Inc.

Levine, S. B., Brown, G., Coleman, E., Cohen-Kettenis, P., Hage, J. J., Van Maasdam, J., et al. (1998). The standards of care for gender identity disorders (5th version). Düsseldorf: Symposion.

Maria (pseudonym). (2004). Maria's Story. Retrieved August 5, 2006, from Transsexual Women's Successes: Links and Photos of Lynn Conway's Website: http://ai.eecs.umich.edu/people/conway/ TSsuccesses/Maria.html

McCain, R. S. (2003, Nov. 25). University investigates ethics of sex researcher. The Washington Times.

McCloskey, D. N. (1999). Crossing: A memoir. Chicago: University of Chicago Press.

McCloskey, D. (2003a, November). Queer science. Reason Online. Retrieved September 29, 2006, from http://www.reason.com/ 0311/cr.dm.queer.shtml

McCloskey, D. (2003b, December 19). Transsexual travesty [Letter to the editor]. Chicago Reader. Retrieved February 29, 2008, from https://securesite.chireader.com/cgi-bin/Archive/abridged2.bat? path=2003/031219/LETTERS/MCCLOSK\&search=mccloskey

McCloskey, D., \& Conway, L. (2003, July 29). Deirdre McCloskey and Lynn Conway file a formal complaint with the Vice-President of Research of Northwestern University regarding the research conduct of J. Michael Bailey. Retrieved December 12, 2006, from http://ai.eecs.umich.edu/people/conway/TS/Bailey/McCloskeyConway-complaint.html

Meyerowitz, J. (2002). How sex changed: A history of transsexuality in the United States. Cambridge: Harvard University Press.

Mundy, L. (2003, March 23). Codes of behavior. The Washington Post, p. BW09.

Office for the Protection of Research Subjects. (n.d.). Institutional Review Board. Retrieved January 3, 2007, from Northwestern University Website: http://www.research.northwestern.edu/research/oprs/irb/

Osborne, D. (2003). [Review of the book The man who would be queen]. Out Magazine.

Raymond, J. G. (1979). The transsexual empire: The making of the shemale. Boston: Beacon Press.

Rendon, J. (1999, December 16-22). Doctor strange love. Metro, Silicon Valley's Weekly Newspaper. Retrieved March 22, 2007, from http:// www.metroactive.com/papers/metro/12.16.99/sexology-9950.html

Ritchie, D. A., \& Shopes, L. (2003). Oral history excluded from IRB review [writing for the Oral History Association and the American Historical Association]. Retrieved January 1, 2007, from http:// alpha.dickinson.edu/oha/org_irb.html

Rodkin, D. (2003, December 12). Sex and transsexuals. Chicago Reader, 33(11), 1, 30-33.

Roughgarden, J. (2003, April 25). Psychology lecture lacks sensitivity to sexual orientation. The Stanford Daily. Retrieved December 10, 2006, from http://daily.stanford.edu/article/2003/4/25/psychology LectureLacksSensitivityToSexualOrientation

Sauer, N. (2003, October). Junk science and Michael Bailey. Transgender Community News, pp. 25-27. 
Schroder, M., \& Carroll, R. (1999). New women: Sexological outcomes of male-to-female gender reassignment surgery. Journal of Sex Education and Therapy, 24, 137-146.

Smith, Y. L., van Goozen, S. H., Kuiper, A. J., \& Cohen-Kettenis P. T. (2005). Transsexual subtypes: Clinical and theoretical significance. Psychiatry Research, 137, 151-160.

Stoller, R. J. (1971). The term "transvestism." Archives of General Psychiatry, 24, 230-237.

Stone, S. (1991). The empire strikes back: A posttranssexual manifesto. In J. Epstein, \& K. Straub (Eds.), Body guards: The cultural politics of gender ambiguity (pp. 280-304). New York: Routledge.

Triea, K. (1999). Power, orgasm, and the Psychohormonal Research Unit. In A. D. Dreger (Ed.), Intersex in the age of ethics (pp. 141144). Hagerstown, MD: University Publishing Group.

Triea, K. (2006, September 28). Interview with Alice Dreger; revised transcript returned October, 5, 2006.

United States Department of Health and Human Services. (2005). Code of Federal Regulations, Title 45, Part 46, "Protection of Human Subjects." Retrieved March 25, 2007, from United States Department of Health \& Human Services Website: http://www. hhs.gov/ohrp/humansubjects/guidance/45cfr46.htm

van Goozen, S. H., Slabbekoorn, D., Gooren, L. J., Sanders, G., \& Cohen-Kettenis, P. T. (2002). Organizing and activating effects of sex hormones in homosexual transsexuals. Behavioral Neuroscience, 116, 982-988.

Velasquez, S. A. (2004). Book review: The man who would be queen. Retrieved March 25, 2007, from http://transkids.us/review.html

Walker, P. A., Berger, J. C., Green, R., Laub, D. R., Reynolds, C. L., \& Wollman, L. (1990). The Harry Benjamin International Gender Dysphoria Association's standards of care [version 4]. Sonoma, CA: Harry Benjamin International Gender Dysphoria Association.

Wallen, K. (2006, July 26). Interview with Alice Dreger; revised transcript returned July 27, 2006.

Wilson, R. (2003a, June 20). "Dr. sex": A human-sexuality expert creates controversy with a new book on gay men and transsexuals. The Chronicle of Higher Education, p. 8.

Wilson, R. (2003b, July 25). Transsexual 'subjects' complain about professors' research methods. The Chronicle of Higher Education, p. 10.

Wilson, R. (2003c, Dec. 19). Northwestern U. psychologist accused of having sex with research subject. The Chronicle of Higher Education, p. 17.

Wilson, R. (2004, Dec. 10). Northwestern U. will not reveal results of investigation into sex researcher. The Chronicle of Higher Education, p. 10. 